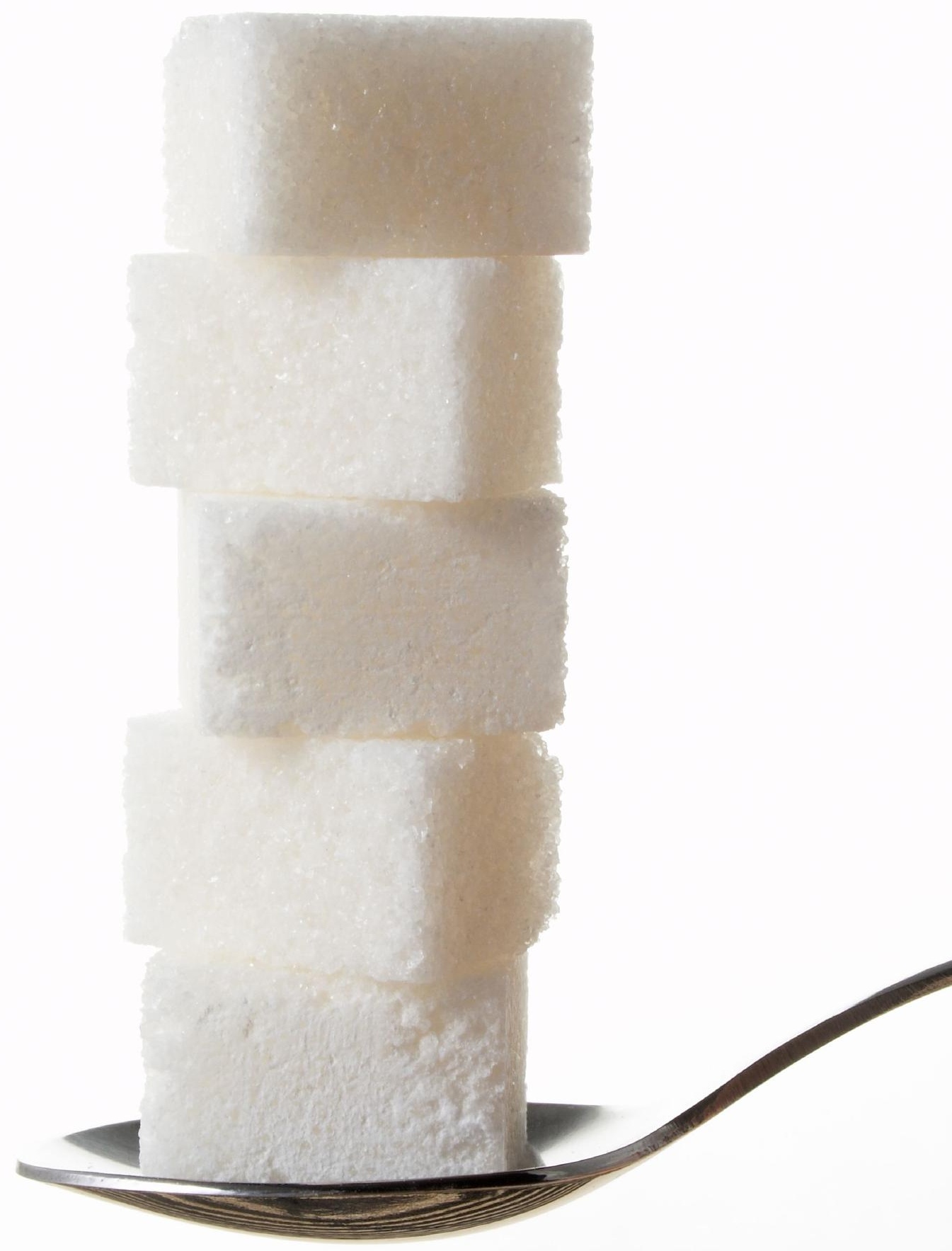

Janneke Hilderink

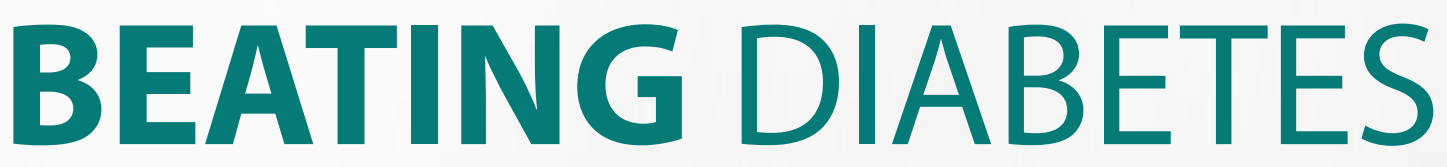

Strategies to improve pancreatic islet transplantation 


\section{Beating diabetes: \\ Strategies to improve pancreatic islet transplantation}

Janneke Hilderink

2013 


\section{Members of the Graduation Committee}

\section{Chairman:}

Prof. Dr. G. van der Steenhoven (University of Twente)

\section{Promoters:}

Prof. Dr. C. A. van Blitterswijk (University of Twente)

Prof. Dr. M. Karperien (University of Twente)

\section{Co-promoter:}

Dr. A. A. van Apeldoorn (University of Twente)

\section{Members:}

Dr. F. Carlotti (Leiden University Medical Center)

Prof. Dr. M. Gotthardt (Radboud University Nijmegen Medical Center)

Dr. P. de Vos (University Medical Center Groningen)

Prof. Dr. J. de Boer (University of Twente)

Prof. Dr. J. L. Herek (University of Twente)

Prof. Dr. Ir. P. Jonkheijm (University of Twente)

\section{Beating diabetes: \\ Strategies to improve pancreatic islet transplantation}

Janneke Hilderink

PhD Thesis, University of Twente, Enschede, The Netherlands

The research described in this thesis was supported by the Dutch Diabetes Cell Therapy Initiative (DCTI), the Dutch Diabetes Research Foundation as part of the DCTI, and the Dutch Program for Tissue Engineering (DPTE). This publication was supported by the Netherlands Society for Biomaterials and Tissue Engineering.

ISBN: 978-90-365-0775-2

Copyright: J. Hilderink 2013, Enschede, The Netherlands. Neither this thesis nor its parts may be reproduced without written permission of the author.

Cover design: Els Hendrikson. 


\title{
BEATING DIABETES: \\ STRATEGIES TO IMPROVE PANCREATIC ISLET TRANSPLANTATION
}

\section{DISSERTATION}

\author{
to obtain \\ the degree of doctor at the University of Twente, \\ on the authority of the rector magnificus, \\ Prof. Dr. H. Brinksma, \\ on the account of decision of the graduation committee, \\ to be publicly defended \\ on Thursday, October $17^{\text {th }} 2013$ at 16.45 hours
}

by

Janneke Hilderink

Born on October $18^{\text {th }}, 1985$

in Enschede, The Netherlands 
This dissertation has been approved by:

Prof. Dr. C. A. van Blitterswijk (Promoter)

Prof. Dr. M. Karperien (Promoter)

Dr. A. A. van Apeldoorn (Co-promoter) 


\section{Summary}

Type 1 diabetes is a chronic disease that is caused by nearly complete destruction of insulin producing beta-cells in the islets of Langerhans, affecting approximately 25 million people worldwide. Prior to the discovery of insulin, diabetes most certainly led to death. To date, patients with type 1 diabetes require daily insulin injections to control their blood glucose levels. Although this therapy is effective, it lacks precise glycemic control which on the long term increases the risk of developing life-threatening diseases such as heart disease, stroke, and kidney failure.

Patients with type 1 diabetes who have had a kidney transplant or who suffer from severe hypoglycemia unawareness might benefit from intrahepatic transplantation of donor islets, according to the so-called 'Edmonton protocol'. This procedure has worldwide been conducted over 750 times. Although the initial results are promising, only $10 \%$ of patients remained insulin-independent five years after treatment, which together with a lack of sufficient quantities of donor tissue and the need for lifelong immunosuppressive therapy have hampered its widespread application.

This thesis describes several strategies that aim at improving the current pancreatic islet transplantation procedure. It starts with a general introduction to provide background information on diabetes, the discovery of insulin, and pancreatic islet transplantation as a potential treatment for type 1 diabetes (Chapter 1). In Chapter 2 , the requirements to create an optimal tissue-engineered construct for successful islet transplantation are reviewed.

To monitor donor islet quality prior to transplantation, efficient imaging methods are required. In Chapters 3 and 4, we introduce Raman spectroscopy to characterize cells in a non-destructive and label-free manner. Chapter 3 describes the potential of Raman spectroscopy to monitor differentiation of human mesenchymal stromal cells. We studied molecular changes that occur during in vitro differentiation of these cells. In addition, we evaluated Raman spectral changes associated with cell fixation methods. Next, we used Raman spectroscopy to characterize more complex biological tissues. We measured human donor islets of Langerhans and revealed Raman markers that allow the label-free identification of insulin and glucagon within these tissues (Chapter 4).

Donor shortage remains a major challenge in pancreatic islet transplantation. Therefore, it is crucial to use the available islet tissue in the most efficient way. To reduce diffusion barriers and improve islet survival after isolation, we developed an agarose microwell platform for controlled aggregation of human donor islet cells 
(Chapter 5). This platform enables the generation of islets with optimal dimensions. We observed that human islet cell aggregates with a diameter of $100-500 \mu \mathrm{m}$ best resembled the physiological conditions of intact pancreatic islets. Moreover, highthroughput engineering of homogenous human islet cell aggregates using our microwell platform facilitates a variety of research applications, such as in vitro compound screening.

Intrahepatic islet transplantation has been associated with severe islet loss which has stimulated the development of extrahepatic transplantation sites, including various (modified) biomaterials. In Chapter 6, we introduce microcontact printing to modify biomaterials that can serve as a scaffold for pancreatic islet transplantation. We successfully produced patterns of fibronectin on PDMS and PEOT/PBT biomaterials, on which controlled immobilization of intact human donor islets and controlled cell-cluster formation of dispersed human donor islet cells was achieved.

Finally, Chapter 7 reflects on the results presented in this thesis and discusses how these may ultimately lead to better ways to treat type 1 diabetes. 


\section{Samenvatting}

Diabetes type 1 is een chronische ziekte die wordt veroorzaakt door een bijna volledige destructie van insuline producerende beta-cellen in de eilandjes van Langerhans, die wereldwijd ongeveer 25 miljoen mensen treft. Vóór de ontdekking van insuline had deze ziekte vrijwel altijd de dood tot gevolg. Vandaag de dag zijn patiënten met diabetes type 1 afhankelijk van dagelijkse insuline injecties om hun bloedsuikerspiegels onder controle te houden. Hoewel dit een effectieve therapie is, is optimale beheersing van de bloedsuikerspiegel vaak moeilijk te realiseren. Op lange termijn verhoogt dit de kans op het ontwikkelen van levensbedreigende ziektes, zoals hart- en vaatziektes, beroerte of nierfalen.

Patiënten met diabetes type 1 die een niertransplantatie hebben ondergaan of die lijden aan ernstige hypoglykemische periodes en deze lage bloedsuikerspiegels niet tijdig herkennen (hypoglycemic unawareness) kunnen baat hebben bij intrahepatische eilandjestransplantatie volgens het zogeheten 'Edmonton protocol'. Wereldwijd is deze therapie meer dan 750 keer uitgevoerd. Hoewel de initiële resultaten veelbelovend zijn, blijft na vijf jaar slechts $10 \%$ van de behandelde patiënten insuline-onafhankelijk, wat samen met het tekort aan orgaandonoren en de behoefte aan levenslange immunosuppressiva de brede toepassing van deze therapie heeft belemmerd.

Dit proefschrift beschrijft een aantal strategieën die gericht zijn op verbetering van de huidige procedure voor eilandjestransplantatie. Het begint met een algemene introductie waarin achtergrondinformatie wordt gegeven over diabetes, de ontdekking van insuline en eilandjestransplantatie als mogelijke therapie voor diabetes type 1 (hoofdstuk 1). Hoofdstuk 2 beschrijft de voorwaarden voor het creëren van een optimaal construct voor eilandjestransplantatie door middel van weefselregeneratie (tissue engineering).

Om voorafgaand aan de transplantatie de kwaliteit van de eilandjes te bewaken, zijn efficiënte beeldvormingstechnieken nodig. In hoofdstukken 3 en 4 wordt het gebruik van Raman spectroscopie voor het niet-destructief en labelvrij karakteriseren van cellen geïntroduceerd. Hoofdstuk 3 beschrijft het gebruik Raman spectroscopie voor het bekijken van differentiatie van humane mesenchymale stromale cellen, waarbij we de moleculaire veranderingen die optreden als gevolg van differentiatie hebben bestudeerd. Daarnaast hebben we de veranderingen in het Raman signaal als gevolg van cel fixatiemethoden bestudeerd. Vervolgens hebben we Raman spectroscopie gebruikt om meer complexe biologische weefsels te karakteriseren. We hebben humane donor eilandjes van Langerhans gemeten waarbij we Raman markers voor het identi- 
ficeren van insuline en glucagon hebben ontdekt (hoofdstuk 4).

Het gebrek aan orgaandonoren blijft een belangrijke uitdaging rondom eilandjestransplantatie. Daarom is het van groot belang om het beschikbare donor materiaal zo efficiënt mogelijk te benutten. Om diffusiebarrières te verkleinen en de overleving van eilandjes na isolatie te verbeteren hebben we een agarose microwell platform ontwikkeld voor het gecontroleerd aggregeren van cellen van humane donor eilandcellen (hoofdstuk 5). Dit platform maakt het mogelijk om eilandjes van optimale grootte te genereren. We zagen dat aggregaten van humane eilandcellen met een afmeting van 100-500 $\mu \mathrm{m}$ de meeste gelijkenissen vertonen met intacte eilandjes van Langerhans. Bovendien kan het 'high-throughput' produceren van homogene aggregaten van humane eilandcellen met behulp van ons platform verschillende onderzoekstoepassingen, zoals het in vitro screenen van medicijnen, vergemakkelijken.

Bij intrahepatische eilandjestransplantatie gaat een groot deel van de getransplanteerde eilandjes verloren. Dit heeft de ontwikkeling van extrahepatische transplantatielocaties, waaronder verschillende (gemodificeerde) biomaterialen, gestimuleerd. In hoofdstuk 6 wordt microcontactprinting geïntroduceerd voor het modificeren van biomaterialen die kunnen dienen als dragermateriaal voor eilandjestransplantatie. We hebben succesvol patronen van fibronectine op verschillende soorten polymere biomaterialen (PDMS en PEOT/PBT) geproduceerd, waarop we vervolgens gecontroleerde immobilisatie van donor eilandjes en gecontroleerde clustervorming van humane eilandcellen konden realiseren.

Hoofdstuk 7 reflecteert tenslotte de resultaten uit dit proefschrift en bediscussieert hoe deze uiteindelijk kunnen leiden tot betere behandelmethodes voor diabetes type 1. 


\section{Table of Contents}

1 General introduction and thesis outline 1

1.1 Diabetes mellitus . . . . . . . . . . . . . . . . . . . . . . . . . . . . . .

1.2 The discovery of insulin . . . . . . . . . . . . . . . . . . 2

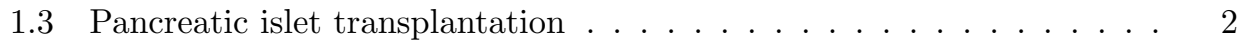

1.4 Aims and outline of this thesis . . . . . . . . . . . . . . 4

2 Critical parameters for islet tissue engineering 9

2.1 Introduction . . . . . . . . . . . . . . . . . 11

2.2 Islet cell-cell interactions . . . . . . . . . . . . . . . . . . . . . 11

2.2.1 Importance of cellular organization within pancreatic islets . . 11

2.2.2 Beta-cells require homotypic cell-cell contact . . . . . . . . . . 13

2.2.3 Novel culture models facilitate cell-cell contact . . . . . . . . . 14

2.3 Role of other cell types . . . . . . . . . . . . . . . . . . . . . . . 14

2.3.1 Endothelial cells promote revascularization . . . . . . . . . . 14

2.3.2 Immunomodulatory properties of MSCs . . . . . . . . . . . . 15

2.4 Cell-matrix interactions . . . . . . . . . . . . . . . . . 16

2.4.1 Extracellular matrix of pancreatic islets . . . . . . . . . . 16

2.4 .2 Collagen . . . . . . . . . . . . . . . . 16

2.4 .3 Laminin . . . . . . . . . . . . . . . . . . . . . . . . . . . . . . 17

2.4 Fibronectin . . . . . . . . . . . . . . . . 17

2.4.5 Combinations of natural ECM proteins . . . . . . . . . . 18

2.4.6 Synthetic ECM . . . . . . . . . . . . . . . . . . 18

$2.53 \mathrm{D}$ islet morphology and function . . . . . . . . . . . . . . 18

2.6 Beta-cell interactions with biopolymer films . . . . . . . . . . . . . . . 19

2.7 Conclusions and recommendations . . . . . . . . . . . . . . . . 19

3 Label-free monitoring of hMSC differentiation 29

3.1 Introduction . . . . . . . . . . . . . . . . . . . . . . . . . . . . .

3.2 Materials and methods . . . . . . . . . . . . . . . . . . . . . . . . . . . . . . . . 32

3.2.1 Cell culture . . . . . . . . . . . . . . . . 32

3.2.2 Choice of substrate for Raman measurements . . . . . . . . . . 32

3.2.3 Cell fixation methods . . . . . . . . . . . . . . . 32

3.2.4 Cell differentiation experiments . . . . . . . . . . . . . . . . . 32

3.2.5 Histological analysis . . . . . . . . . . . . . . . . . 33 
3.2.6 Confocal Raman microspectroscopy . . . . . . . . . . . . . 33

3.2.7 Raman data analysis . . . . . . . . . . . . . . . . . . . . 34

3.3 Results. . . . . . . . . . . . . . . . . . . 34

3.3.1 Effects of fixation on Raman fingerprint of hMSCs . . . . . . . 34

3.3.2 Raman spectroscopy of adipogenic and osteogenic differentiation of living hMSCs . . . . . . . . . . . . . . . . . . 35

3.3.3 Hyperspectral Raman imaging of hMSC differentiation . . . . . 36

3.4 Discussion . . . . . . . . . . . . . . . . . . . . . . 38

3.5 Conclusion .......................... 40

4 Label-free detection of insulin and glucagon in human islets of Langerhans

4.1 Introduction . . . . . . . . . . . . . . . . . . . . . 47

4.2 Materials and methods . . . . . . . . . . . . . . . . . . . . . . . . . . . . . . 48

4.2.1 Cell culture . . . . . . . . . . . . . . . . . . . 48

4.2.2 Human islet culture . . . . . . . . . . . . . . . . . . . 48

4.2 .3 Immunohistochemistry . . . . . . . . . . . . . . . . . . . . . . 48

4.2.4 Confocal Raman microspectroscopy . . . . . . . . . . . . . . 49

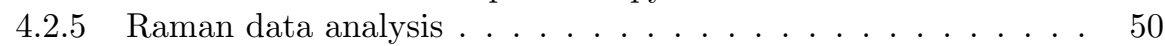

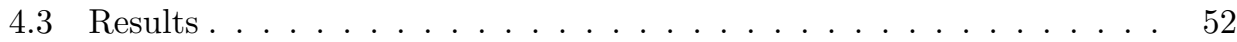

4.3.1 Raman spectra of purified hormones . . . . . . . . . . . 52

4.3.2 Raman fingerprint of alpha- and beta-cell lines . . . . . . . . . 52

4.3.3 Raman imaging of INS-1E beta-cells . . . . . . . . . . . . . . 54

4.3.4 Raman imaging of human pancreatic islets . . . . . . . . 57

4.3.5 High resolution Raman imaging of human pancreatic islets . . 57

4.4 Discussion . . . . . . . . . . . . . . . . . . 57

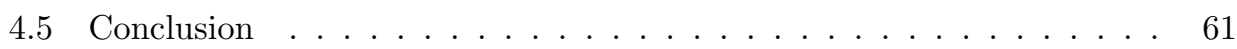

5 Microwells for controlled aggregation of human islet cells $\quad 65$

5.1 Introduction . . . . . . . . . . . . . . . . . 67

5.2 Materials and methods . . . . . . . . . . . . . . . . . . 68

5.2 .1 Insulinoma cell culture . . . . . . . . . . . . . . 68

5.2 .2 Primary human islet culture . . . . . . . . . . . 68

5.2.3 Agarose microwell fabrication and cell aggregate formation . . 68

5.2.4 Scanning Electron Microscopy . . . . . . . . . . . . . 69

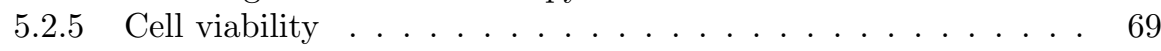

5.2 .6 Histological analysis . . . . . . . . . . . . . . . . . 69

5.2.7 Glucose stimulated insulin secretion test (GSIST) . . . . . . . . 70

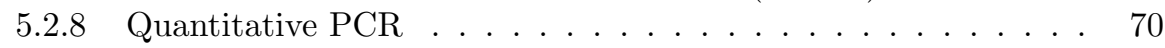

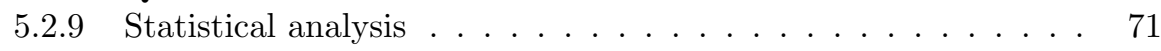

5.3 Results............................. 71

5.3.1 Fabrication and validation of microwell platform . . . . . . . 71

5.3.2 Controlled generation of insulinoma and primary human islet cell aggregates . . . . . . . . . . . . . . 71

5.3.3 INS-1E insulinoma cell aggregates are viable and functional . . 74 
5.3.4 Human islet cell aggregates are viable and functional . . . . . . 74

5.4 Discussion . . . . . . . . . . . . . . . . . . . . 74

5.5 Conclusions . . . . . . . . . . . . . . . . . . . 77

6 Size-controlled cell cluster formation on patterned biomaterials $\quad 83$

6.1 Introduction . . . . . . . . . . . . . . . . . . . 85

6.2 Materials and methods . . . . . . . . . . . . . . . . . . 85

6.2 .1 Cell culture . . . . . . . . . . . . . . 85

6.2.2 Human islet culture . . . . . . . . . . . . . . . 86

6.2 .3 Biomaterials ...................... 86

6.2.4 Fabrication of microcontact printed substrates . . . . . . . . 86

6.2.5 Cell seeding on microcontact printed substrates . . . . . . . . . 87

6.2.6 Scanning Electron Microscopy . . . . . . . . . . . . . . . 87

6.2.7 Cell viability . . . . . . . . . . . . . . . . . . 87

6.2 .8 Immunohistochemistry . . . . . . . . . . . . . . . . . . 87

6.2.9 Glucose stimulated insulin secretion test (GSIST) . . . . . . . . 88

6.2.10 Circularity measurements . . . . . . . . . . . . . . 88

6.3 Results.......................... 89

6.3.1 Fabrication of microcontact printed biomaterials for controlled cell aggregation . . . . . . . . . . . . . . . . 89

6.3.2 Seeding density determines dimensions of uniform INS-1E cell clusters . . . . . . . . . . . . . . . . 89

6.3.3 Multilayered INS-1E cell clusters are viable and functional . . . 89

6.3.4 Self-assembly of co-cultures on microcontact printed PDMS . . 93

6.3.5 Immobilization of human donor islets on microcontact printed

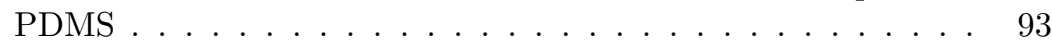

6.3.6 Reassembly of dispersed human islet cells on microcontact printed substrates . . . . . . . . . . . . . . . 94

6.4 Discussion . . . . . . . . . . . . . . . . . . . . 96

6.5 Conclusion . . . . . . . . . . . . . . . . . . . . 98

7 General conclusions and outlook 103

7.1 Abstract . . . . . . . . . . . . . . . . . . 104

7.2 Role of imaging methods . . . . . . . . . . . . . . . . . . . . . . . . . 104

7.3 Generation of (artificial) islets . . . . . . . . . . . . . . . 105

7.4 Towards an implantable construct . . . . . . . . . . . . . . 105

7.5 Concluding remarks . . . . . . . . . . . . . . 106

$\begin{array}{ll}\text { Curriculum Vitae } & 109\end{array}$

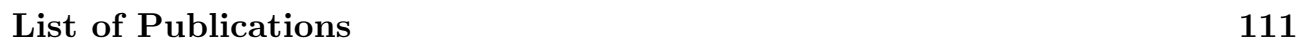

$\begin{array}{ll}\text { Acknowledgements } & 113\end{array}$ 

Chapter 1

General introduction and thesis outline 


\subsection{Diabetes mellitus}

The term diabetes mellitus is derived from the Greek word diabetes, meaning 'to pass through' and the latin word mellitus, meaning 'honeyed' or 'sweet', referring to the abnormally high levels of glucose in the blood and urine of diabetes patients. Type 2 diabetes, which makes up about $90 \%$ of all cases of diabetes, is a result of insulin resistance, sometimes combined with relative insulin deficiency. Type 1 diabetes is caused by an autoimmune destruction of the insulin-producing beta-cells in the pancreas, resulting in absolute insulin deficiency [1]. Worldwide, as of 2011, an estimated 366 million people suffer from diabetes, and this number is expected to rise to 552 million in 2030 [2]. To control their blood glucose levels, patients require daily insulin injections. need to self-administer exogenous insulin daily. Although it is effective in regulating blood glucose levels, this method lacks precise glycaemic control which on the long term may cause severe complications like neuropathy, nephropathy and retinopathy, increasing the risk of developing life-threatening diseases [3]. Consequently, diabetes has a significant adverse economic impact [4].

\subsection{The discovery of insulin}

Prior to the discovery of insulin, treatment of diabetes was limited to dietary manipulation and the disease most certainly led to death. In 1869, the German anatomist Paul Langerhans identified groups of hormone-producing cells in the pancreas [5], which were later called the 'islets of Langerhans' [6]. Twenty years later, in 1889, von Mering and Minkowski discovered that removal of the pancreas led to development of all signs and symptoms of diabetes in dogs, implicating that diabetes is a pancreatic disease [7]. Sharpey-Schafer found in 1910 that patients with diabetes lack a single chemical that is normally produced by the pancreas, which he then called insulin, derived from the latin word insula, meaning 'island'. The existence of insulin was further clarified in 1922, when Banting and Best demonstrated that diabetes in dogs could be reversed by treating them with pancreatic extracts [8]. They continued their research and purified the hormone insulin from bovine pancreases, which led to the availability of an effective treatment for diabetes for which Banting and Macleod received the Nobel Prize in 1923 [9]. In 1922, the 14-year-old Leonard Thompson (Toronto, Canada) was the first person to receive insulin injections to successfully treat his diabetes. The first biosynthetic human insulin was approved to the market in 1982 [10]. To date, daily insulin injections are still the gold standard for diabetes treatment.

\subsection{Pancreatic islet transplantation}

Patients who have had a kidney transplant or who suffer from severe hypoglycemia unawareness might benefit from islet transplantation as an alternative to whole pancreas transplantation. In 1972, Ballinger and Lacy successfully reversed diabetes in rodent models [11]. In 1990, Sharp et al. reported the first case of insulin-independence, 


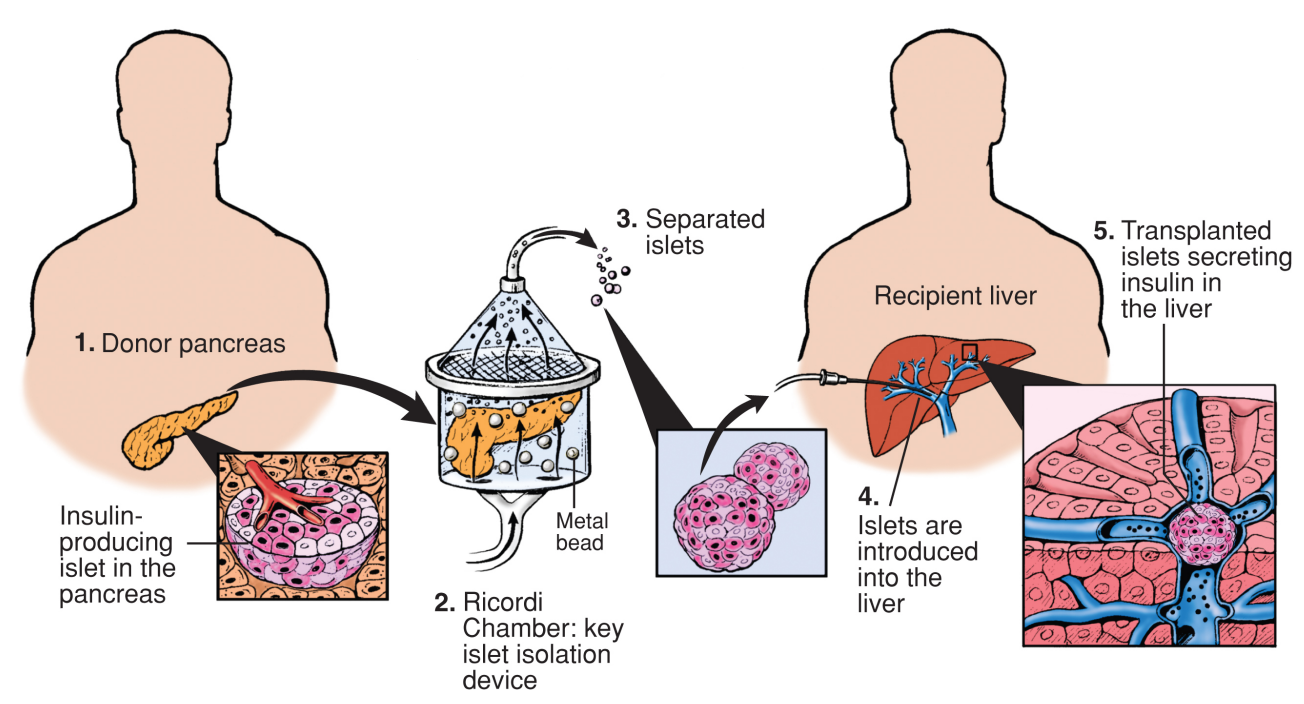

Figure 1.1: Schematic representation of pancreatic islet transplantation procedure. The pancreas is isolated from the donor (1) and islets are separated from the surrounding tissue using a Ricordi Chamber (2). The quality of the islets is evaluated and islets are introduced via a catheter into the liver of the patient (4), where they reside and begin releasing insulin (5). (C)2005 Diabetes Research Institute, University of Miami.

which lasted one month [12]. The real breakthrough came in 2000 with the so-called 'Edmonton protocol', developed by James Shapiro and Jonathan Lakey [13, 14]. The islet transplantation procedure, involving the intraportal infusion of allogeneic islets, is schematically shown in Figure 1.1. The donor pancreas is isolated, infused with collagenase and transferred to a digestion chamber to separate the islets from exocrine tissue. After evaluation of the purity and viability, the donor islets are injected into the portal vein of the liver. The initial clinical results are promising as they achieved 100\% insulin-independence in seven patients, one year after treatment [14]. However, later it became clear that the promising initial results decline with time and that only $10 \%$ of patients were insulin-independent five years after treatment $[15,16]$. Since 2000, several modifications of the original protocol have been implemented to improve clinical results and over 750 islet transplants have been conducted worldwide [17]. Current data on islet transplantation outcomes show insulin-independence rates over $60 \%$ after two years, which strongly declines to only $15 \%$ insulin-independence at five years posttransplant. However, persistent c-peptide secretion and complete protection from hypoglycemic events could be achieved in $>70 \%$ of recipients (Figure 1.2) [17]. Although islet transplantation provides a promising therapy, a lack of sufficient quantities of donor tissue and the need for lifelong immunosuppressive therapy are two major obstacles that currently prevent its widespread application [16]. Multiple research efforts that aim at improving pancreatic islet transplantation are currently 


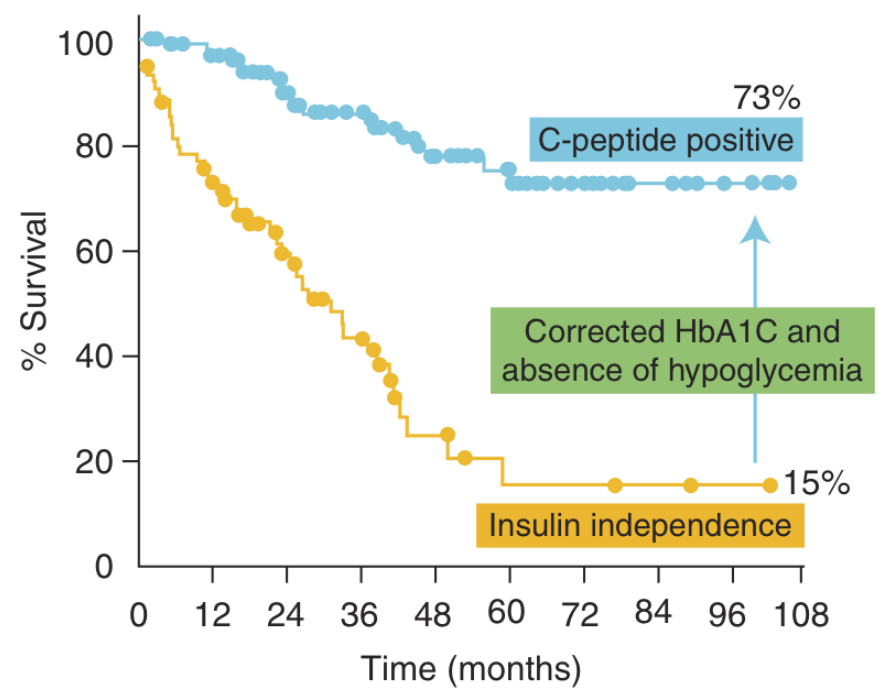

Figure 1.2: Nine-year insulin-independence and c-peptide islet graft rates. Insulin-independence rates strongly decline, with only $15 \%$ insulinindependence at five years posttransplant. C-peptide secretion is persistent and complete protection from hypoglycemic events was achieved in $>70 \%$ of recipients. Adapted from [17].

under investigation. To circumvent the problem of donor shortage, researchers evaluate the use of stem cells and other cell types to serve as an alternative source of insulin-producing cells $[18,19]$. Others focus on reducing or eliminating immune attack after transplantation by microencapsulation [20, 21]. In addition, noninvasive monitoring is suggested to aid in tracking engrafted islets [22].

\subsection{Aims and outline of this thesis}

In this thesis, we explore several strategies that aim at improving the current islet transplantation procedure. Chapter 2 gives a general introduction into tissue engineering and discusses the requirements to create an optimal tissue-engineered construct for successful islet transplantation. Chapter 3 describes the use of Raman spectroscopy to monitor the multilineage potential of human mesenchymal stromal cells, in which we studied chemical changes that occur during in vitro differentiation of these cells. In addition, we evaluated Raman changes associated with cell fixation methods. Chapter 4 explores the use of Raman microspectroscopy as a method to characterize islets of Langerhans before transplantation in patients with type 1 diabetes. We reveal Raman markers that allow the identification of insulin and glucagon, and performed high-resolution label-free imaging of these hormones within human 
donor islets. Chapter 5 describes a high-throughput microwell platform optimized for the generation of stable and uniformly sized aggregates of human islet cells. This platform provides a tool to engineer islets with optimal dimensions and supports the cell-cell contact that is required for beta-cells to survive and function. Chapter 6 introduces the use of microcontact printing to produce patterns of fibronectin on PDMS and PEOT/PBT biomaterials. These modified biomaterials can serve as a scaffold for extrahepatic transplantation to improve the efficiency of the current pancreatic islet transplantation procedure. Finally, Chapter 7 provides an overview of the results described in this thesis and discusses future perspectives for improving pancreatic islet transplantation for the treatment of type 1 diabetes. 


\section{References}

1. Mathis, D., L. Vence, and C. Benoist, beta-Cell death during progression to diabetes. Nature, 2001. 414(6865): p. 792-8.

2. Whiting, D.R., et al., IDF diabetes atlas: global estimates of the prevalence of diabetes for 2011 and 2030. Diabetes Res Clin Pract, 2011. 94(3): p. 311-21.

3. Nathan, D.M., Long-term complications of diabetes mellitus. N Engl J Med, 1993. 328(23): p. 1676-85.

4. Bruno, G. and A. Landi, Epidemiology and costs of diabetes. Transplant Proc, 2011. 43(1): p. 327-9.

5. Langerhans, P. and H. Morrison, Contributions to the microscopic anatomy of the pancreas. 1937, Baltimore,: The Johns Hopkins press. 1 p.l., 39 p.

6. Sakula, A., Paul Langerhans (1847-1888): a centenary tribute. J R Soc Med, 1988. 81(7): p. 414-5.

7. Bliss, M., The history of insulin. Diabetes Care, 1993. 16 Suppl 3: p. 4-7.

8. Banting, F.G., et al., Pancreatic extracts in the treatment of diabetes mellitus. 1922, Toronto: The University library: pub. by the librarian. 6 p.

9. Bliss, M., The discovery of insulin. 1982, Chicago: University of Chicago Press. 304 p., 16 p. of plates.

10. Chance, R.E. and B.H. Frank, Research, development, production, and safety of biosynthetic human insulin. Diabetes Care, 1993. 16 Suppl 3: p. 133-42.

11. Ballinger, W.F. and P.E. Lacy, Transplantation of intact pancreatic islets in rats. Surgery, 1972. $72(2)$ : p. 175-86.

12. Scharp, D.W., et al., Insulin independence after islet transplantation into type I diabetic patient. Diabetes, 1990. 39(4): p. 515-8.

13. Shapiro, A.M. and J.R. Lakey, Future trends in islet cell transplantation. Diabetes Technol Ther, 2000. 2(3): p. 449-52.

14. Shapiro, A.M., et al., Islet transplantation in seven patients with type 1 diabetes mellitus using a glucocorticoid-free immunosuppressive regimen. N Engl J Med, 2000. 343(4): p. 230-8.

15. Ryan, E.A., et al., Five-year follow-up after clinical islet transplantation. Diabetes, 2005. 54(7): p. 2060-9.

16. Langer, R.M., Islet transplantation: lessons learned since the Edmonton breakthrough. Transplant Proc, 2010. 42(5): p. 1421-4.

17. McCall, M. and A.M. Shapiro, Update on islet transplantation. Cold Spring Harb Perspect Med, 2012. 2(7): p. a007823.

18. Carlotti, F., et al., Beta-Cell generation: can rodent studies be translated to humans? J Transplant, 2011. 2011: p. 892453.

19. Carlotti, F., et al., Isolated human islets contain a distinct population of mesenchymal stem cells. Islets, 2010. 2(3): p. 164-73.

20. de Vos, P., et al., Alginate-based microcapsules for immunoisolation of pancreatic islets. Biomaterials, 2006. 27(32): p. 5603-17.

21. de Vos, P., M. Spasojevic, and M.M. Faas, Treatment of diabetes with encapsulated islets. Adv Exp Med Biol, 2010. 670: p 38-53.

22. Andralojc, K., et al., Obstacles on the way to the clinical visualisation of beta 
cells: looking for the Aeneas of molecular imaging to navigate between Scylla and Charybdis. Diabetologia, 2012. 55(5): p. 1247-57. 



\section{Chapter 2}

\section{Tissue engineering of pancreatic islets: what are the critical parameters?}

Janneke Hilderink, Clemens van Blitterswijk, Marcel Karperien and Aart van Apeldoorn 


\begin{abstract}
This study gives an overview of several requirements for successful islet tissue engineering for the treatment of type 1 diabetes. We discuss the need for cell-cell and cell-matrix interactions and describe the role of other cell types in islet tissue engineering. Moreover, the use of biopolymer films for islet transplantation is reviewed. Biomaterials can serve as an artificial transplantation site that can be tailored to mimic the natural islet microenvironment and provide optimal support. However, islet spreading and loss of spherical islet morphology may adversely affect islet function and glucose-responsiveness. A slightly hydrophobic biopolymer would most likely be the best choice for islet tissue engineering. The biomaterial could be enhanced with a combination of natural ECM proteins to provide cell-adhesion points to immobilize the islets while preventing spreading. Restoring islet-ECM interactions by incorporating ECM proteins in novel scaffolds designs could improve transplantation outcome; however, care must be taken when selecting these compounds as some islet-ECM interactions have adverse effects.
\end{abstract}




\section{$2.1 \quad$ Introduction}

Clinical islet transplantation has become a promising therapy for patients with type 1 diabetes [1-3]. However, limited efficacy on the long term has hampered the widespread clinical use. An estimated $60 \%$ of islets are lost shortly after transplantation, which is related to instant blood-mediated inflammatory reaction (IBMR) and exposure to high levels of immunosuppressive drugs, low oxygen tension and mechanical stress [4-8]. In addition, donor islet shortage is a major limiting factor of clinical islet transplantation. To overcome this problem, alternative cell sources such as stem cells and porcine islet xenotransplantation are under consideration. Various cell sources that might lead to an adequate supply of beta-cells for replacement therapy have been discussed in detail [9-12].

Tissue engineering is an interdisciplinary field involving the use of cells and materials to repair or regenerate specific tissues or organ [13]. This is schematically depicted in Figure 2.1. These disciplines may be combined to generate artificial islets using alternative cell sources, restore the extracellular matrix interactions and recreate the islets native environment, resulting in a three-dimensional tissue-engineered constructs. These constructs could serve as extrahepatic transplantation site and may help to improve the efficiency of clinical islet transplantation. Several aspects like cell source, environmental factors and the use of biomaterials for implantation purposes need to be considered in an approach to design the optimal islet containing construct for type 1 diabetes treatment.

The aim of this study is to discuss the requirements and critical parameters for successful islet tissue engineering for type 1 diabetes treatment. We discuss the need for cell-cell and cell-matrix interactions and describe the role of other cell types in islet tissue engineering. In addition, the use of biopolymer films for islet transplantation is reviewed. The optimal construct for islet transplantation should mimic the natural microenvironment of pancreatic islets by facilitating the required cell-cell and cellmatrix interactions, while providing optimal cell support.

\subsection{Islet cell-cell interactions}

\subsubsection{Importance of cellular organization within pancreatic islets}

Islets of Langerhans comprise five endocrine cell types ( $\beta, \alpha, \delta, \epsilon$ and $\mathrm{PP}$ cells) that work together to main glucose homeostasis. The specific cellular organization within pancreatic islets facilitates numerous interactions between islet cells [14], which are associated with normal beta-cell function $[15,16]$. Loss of specific cellular arrangement is therefore likely to result in impaired islet function.

The cellular architecture of islets of Langerhans is dependent on the species. In rodent islets, beta-cells form the central core which is surrounded by a mantle of non-beta-cells [17]. It has been demonstrated that reassembly of dispersed rat pancreatic islet cells results in islet-like aggregates that show the same core and mantle organization. Differential expression of neural cell adhesion molecules (N-CAM) has been shown to be responsible for the establishment and maintenance of the specific 


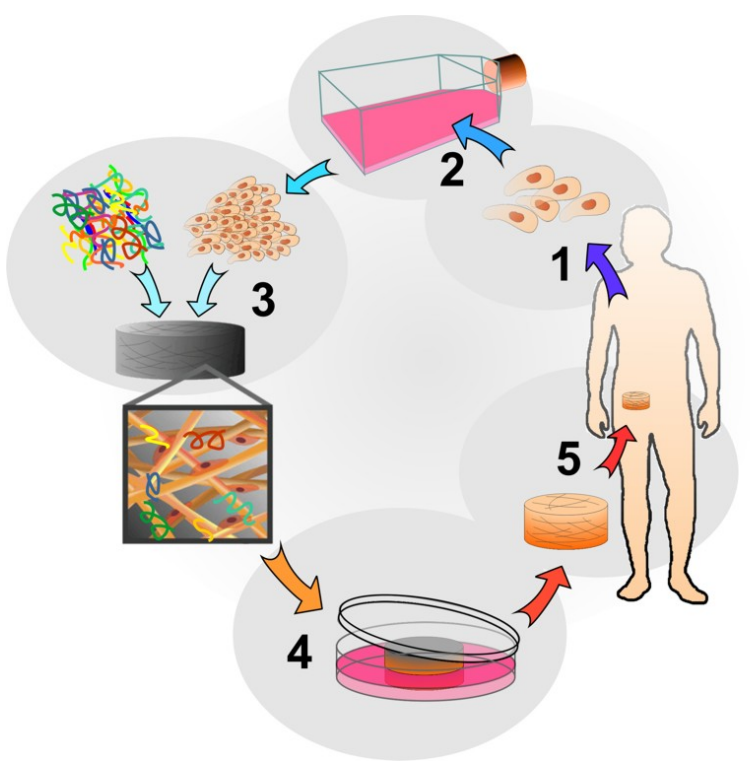

Figure 2.1: Tissue engineering principle. In cell-based tissue engineering, cells are harvested from the patient (1) and expanded in vivo (2). When sufficient cell numbers are obtained, cells (sometimes combined with growth factors (3)) are seeded onto a scaffold (4) and implanted into the patient (5). Adapted from: C.A. van Blitterswijk, Tissue Engineering. Academic Press Series in Biomedical Engineering [Elsevier/Academic press, Amsterdam; London, 2008] pp. xv, 740p.

islet architecture in rodents [18-20]. Perturbation of the core-mantle organization in rodent islets has been associated with decreased insulin secretion [21]. In addition, Bosco et al. demonstrated that homologous but not heterologous contact between pancreatic rat beta-cells increase insulin secretion [15]. These observations suggest that the specific core-mantle segregation in rodent islets is favorable for islet function.

In contrast to rodent islets, intact human islets show a heterogeneous cellular organization in which all endocrine cells are in close contact to blood vessels and beta-cells are randomly intermingled with alpha- and delta-cells [22-24]. Bosco et al. reported that the unique cellular organization of human islets within human pancreata is not maintained in cultured isolated islets, indicating that human islet cells by themselves do not necessarily play an active role in the islets specific cellular arrangement [22]. However, they did not study whether islet morphology was restored after transplantation and whether the unique cellular arrangement is critical for islet function. In chapter 5 of this thesis, we demonstrated that dispersed human islet cells reassemble and form islet cell aggregates with a non-typical cellular arrangement with beta-cells surrounding a core of alpha-cells. The islet cell aggregates were viable and their glucose-responsiveness was maintained up to 7 days of in vitro culture. This 
may suggest that the natural cellular organization of human islets is not necessarily required for normal islet function. However, it has been suggested that the specific cellular organization and the complex cell-cell interactions within pancreatic islets are associated with normal beta-cell function $[15,16]$.

\subsubsection{Beta-cells require homotypic cell-cell contact}

Several studies reported the importance of homotypic cell-cell contact for survival and proper functioning of beta-cells. For example, it has been show that viability and glucose-stimulated insulin secretion of MIN6 cells were increased when cells were cultured in close contact with each other [25-28]. Moreover, glucose-responsiveness was lost when cell-clusters were dispersed, and regained upon cell aggregation [28-30]. Similar results were obtained using primary islet cells of rodent and human origin [31-33]. Intra-islet cell communication, which is crucial in coordinating appropriate insulin release, is largely achieved through gap-junction mediated communication [34]. These gap-junctions synchronize electrical activity and coordinated changes in $\mathrm{Ca}^{2+}$ flux regulate glucose-induced insulin secretion of pancreatic beta-cells which are in electrical contact with six to seven other beta-cells [35-37]. Gap junction are formed by the apposition of connexons from adjacent cells, where each connexon if formed by six connexin proteins. Connexins 36 and 43 are known to play an important in the regulation of pancreatic islet function [38]. Connexin 36 is associated with the regulation of beta-cell gap junctions, while connexin 43 is believed to mediate other islet-cell type channels $[39,40]$. In addition, cell adhesion molecules (CAMs) such as integrins, neural cell adhesion molecule (N-CAM), and epithelial-cadherin (E-CAD) play an important role in cell-cell interactions [18, 41, 42].

Studies have demonstrated that both E-CAD and N-CAM are involved in the cellular organization of pancreatic islets. It has been demonstrated that a loss of E-CAD in beta-cells resulted in impaired insulin secretion, significant reduction of beta-cell mass and decreased insulin content in 2-day-old mice [43]. Both E-CAD and N-CAM are present in beta- and non-beta-cells of primary rat islets, but N-CAM expression levels are much higher in non-beta-cells $[18,20,44]$. Whereas E-CAD is mainly involved in homotypic interactions between beta-cells, N-CAM is important for heterotypic interactions that are required for islet cell type segregation $[18,19,26,45]$. Whereas cell-cell contact has been shown to improve survival and function of betacells, no such effect has been observed for alpha-cells. Brereton et al. demonstrated that $\alpha \mathrm{TC} 1$ maintained as cell aggregates or as cell clusters showed similar secretory responses, indicating that homotypic interactions between alpha-cells are not required for proper cell functioning [26]. Since it has been shown that E-CAD is involved in the regulation of insulin secretion in beta-cells [43], the lack of E-CAD expression in $\alpha \mathrm{TC} 1$ cells might explain why cell-cell contact in alpha-cells does not influence glucagon secretion. These studies emphasize the need for close cellular communication between beta-cells and the other islet cell types to regulate insulin secretion. 


\subsubsection{Novel culture models facilitate cell-cell contact}

Several studies showed that insulin expression of beta-cells can be maintained in three-dimensional cultures, in which cells were cultured as cellular aggregates with close cell-cell contact [46-48]. However, most cell culture systems lack the threedimensional multi-cellular architecture of living tissues. Researchers now focus on the design of novel cell culture assays in an attempt to more closely resemble the cells native environment. Three-dimensional or two-dimensional patterned systems are developed to improve cell-cell contact. Conventional methods for 3D cell culture include the hanging drop method, which has also been used for aggregation of rat islet cells [49-51]. More recently, microwell platforms have been developed and applied for three-dimensional culture of MIN6 cells, pancreatic progenitor cells, and rat islet cells [52-54]. Other methods for controlled cell aggregation include microcontact printing to form three-dimensional beta-cell clusters $[55,56]$. We demonstrated the use of both microwells and microcontact printing for controlled aggregation of human donor islet cells (chapter 5 and 6 of this thesis). In addition, a novel islet tissue engineering approach facilitating pancreatic cell-cell contact has been reported. Researchers describe the generation of functional islet cell sheets composed of pancreatic islet cells. To create these cell sheets, rat islet cells were cultured on laminin-332 (previously named laminin-5 [57]) coated temperature-sensitive PIPAAm culture dishes. The harvested islet cell sheets were functional both in vitro and in vivo, and subcutaneous transplantation of islet sheets in diabetic mice reverted serum hyperglycemia to steady normoglycemic levels $[58,59]$.

\subsection{Role of other cell types}

\subsubsection{Endothelial cells promote revascularization}

In vivo, islets contain a vascular network with a density that is approximately 10 times higher than that of exocrine tissue, which is essential for efficient insulin secretion and nutrient transport [60-62]. The islet vasculature is destroyed during the isolation process, resulting in cell dedifferentiation, apoptosis and necrosis [63]. It has been shown that beta-cells require endothelial signals for their differentiation and function. By secreting vascular endothelial growth factor (VEGF-A), mouse betacells attract endothelial cells to promote vascular development and the formation of a vascular basement membrane. Beta-cells interact with endothelial cells via its vascular basement membrane proteins such as laminin and collagen IV. Laminins bind to the $\alpha 6 \beta 1$-integrin expressed on pancreatic beta-cells, which supports beta-cell proliferation and insulin gene expression $[64,65]$. Moreover it has been shown that not only endothelial cells from the recipient, but also remaining intraislet endothelial cells from the donor contribute to the revascularization process [66]. In addition, Johansson et al. demonstrated that coating human islets with a mixture of endothelial cells and MSCs increases sprout formation, suggesting that these cells have beneficial effects on islet revascularization [8]. A recent study showed that infusion of sertoli cells followed by transplantation of islets that were coated with endothelial 
cells resulted in enhanced islet graft survival and function in an in vivo rat model, compared to untreated islets [67]. In addition, co-transplantation of rat islets with human blood outgrowth endothelial cells in a mouse model improved glycemic levels, increased plasma c-peptide and reduced beta-cell death, compared transplantation of islets alone [68]. These studies suggest that adding exogenous endothelial cells may facilitate survival and function of islets and tissue engineered islet-like clusters.

\subsubsection{Immunomodulatory properties of MSCs}

Long term efficacy following transplantation has been limited due to chronic graft rejection. The ultimate goal is to prevent graft rejection without the need for potentially dangerous and nonspecific immunosuppressive drugs. Mesenchymal stromal cells (MSCs) display immunomodulatory effects, which have been shown to enhance survival and engraftment of allogeneic islet transplants in several animal studies [6971]. Lee at al. studied the effects of MSCs in the development of diabetes in mice. They reported that infusion of hMSCs in immunodeficient recipient mice (Nonobese Diabetic/Severe Combined Immunodeficiency, NOD/SCID) reduced glycemic levels and increased peripheral insulin levels [72]. Others have shown that injection of allogeneic MSCs into prediabetic NOD mice protected islet mass and delayed the onset of diabetes [73]. In addition, it has been demonstrated that MSCs can enhance angiogenesis of rodent islets after transplantation by co-transplantation of MSCs with islets $[74,75]$. In addition, enhanced blood vessel formation was also observed when islets were pre-cultured in MSC-conditioned medium [76]. However, a recent study by Rackham et al., suggests that direct cell-cell contact between MSCs and islets during pre-culturing is required to improve islet graft function in vivo [77].

Several molecules have been associated with the immunomodulatory effects of MSCs [78, 79], such as matrix metalloproteinases-2 and -9 [70], prostaglandin E2 [80], transforming growth factor-beta [81, 82], interleukins-6 and 10 [81, 83], human leukocyte antigen-G5 [84-86], indoleamine-2,3-dioxygenase [80] and nitric oxide [87]. It is likely that these factors are not mutually exclusive and that their contribution to immune suppression may vary between different tissues and species. However, the exact mechanisms underlying the immunomodulatory effects of MSCs remain largely unknown.

Preliminary results regarding the efficacy of MSCs in both preventing allograft rejection and in suppressing immune response in autoimmune diseases, have led to a number of clinical trials in humans. Several clinical trials have been performed to study the feasibility and safety of using MSCs in humans, showing promising results for the treatment several diseases, such as graft versus-host-disease [88-90]. Several human clinical trials evaluating the feasibility of using MSCs in patients with type 1 diabetes are presently underway (www.clinicaltrials.gov). The Uppsala University hospital (Sweden) is currently recruiting participants to study the immunomodulatory properties of MSCs in patients with newly onset of type 1 diabetes. Another study by the Fuzhou General Hospital in China will evaluate the safety and efficacy of cotransplantation of islets and MSCs in patients with type 1 diabetes. The im- 
munomodulatory properties of MSCs make them interesting candidates for treatment of type 1 diabetes.

\subsection{Cell-matrix interactions}

\subsubsection{Extracellular matrix of pancreatic islets}

The extracellular matrix (ECM) is a network of proteins and polysaccharides that provides cell support, regulates intercellular communication, and stores and secretes growth factors. The ECM provides molecular cues that regulate cell behaviour and are important for cell survival, proliferation and function. Extracellular signals are encoded in ECM proteins and polysaccharides that interact with cell membrane receptors. Cell-matrix interactions are mediated by specific cell adhesion molecules (CAM), such as integrins and cadherins, on the surface of the cells. Islet ECM is found in two forms, the interstitial matrix and basement membrane (BM) on the islet periphery. Islet BM consists of fibronectin, collagen IV, and laminin. The extracellular matrix proteins of the islet basement membrane, like collagens and laminins, interact with beta-cells via integrin receptors. Adult human islets cells were found to be positive for $\alpha 3, \alpha 5, \alpha \nu, \beta 1, \beta 3$, and $\beta 5$ integrins, and possibly also express $\alpha 1$ and $\alpha 6$ [91]. An overview of integrin expression in human islets is given in Table 2.1. However, the exact integrin composition in islets remains controversial.

Islet isolation from the pancreas by enzymatic digestion and purification not only destroys the islets vascularization and innervation, but also disrupts islet cell interactions with its extracellular matrix. Inadequate or inappropriate cell-matrix interactions are shown to induce apoptosis, a process called anoikis [92]. Research showed that disruption of the extracellular matrix was associated with decreased beta-cell viability in explanted canine islets [93]. Recreating the beta-cell niche after transplantation may help to improve beta-cell survival and function. Several studies have reported beneficial effects of islet-cell interactions with specific ECM proteins on survival and function of whole islets and individual beta-cells.

\subsubsection{Collagen}

The peripheral ECM of human islets contains several types of collagen. Although collagen IV is abundantly present in the peripheral ECM and perivascular BM of islets, there is no clear evidence for a collagen-integrin binding pathway and the exact role of collagens in endocrine function remains unclear. It has been shown that glucose responsiveness of isolated islets was maintained during in vitro culture in collagen I and/or collagen IV hydrogels [94]. In addition, Lucas-Clerc et al. demonstrated that long-term culture of human islets embedded in collagen I gels showed improved glucose-responsiveness up to 17 days and cell viability up to 8 weeks of culture compared to tissue culture plastic [95]. In contrast, it has been reported that monolayer culture on collagen I results in a loss of insulin secretion [96]. Others showed that integrin-dependent adhesion of adult human beta-cells to a layer of collagen IV resulted in a $40 \%$ decline of insulin content, loss of function and reduced insulin mRNA 
Table 2.1: Integrin subunit expression in human islets, adapted from [91].

\begin{tabular}{ll}
\hline Expression & Subunit \\
\hline Highly likely & $\alpha 3, \alpha 5, \alpha \nu, \beta 1, \beta 3, \beta 5$ \\
Possible or very low level & $\alpha 1, \alpha 6, \beta 4$ \\
Unlikely & $\alpha 2, \beta 2$ \\
\hline
\end{tabular}

levels, which is associated with beta-cell dedifferentiation [97]. These findings suggest that most likely, the positive effects on beta-cell function can be attributed to the three-dimensional environment and not to the collagen itself. In addition, collagen might act as a deposit or storage for other ECM molecules, which in combination could exhibit a synergistic effect on beta-cell function.

\subsubsection{Laminin}

Laminin is prevalent in islet ECM and several studies demonstrate the importance of these proteins for beta-cell functioning. Different laminin isoforms have been identified, however, the expression of these specific isoforms in islets is not well understood. Interactions between beta-cells and laminins are mediated by specific integrins and laminin-specific binding proteins on the surface of the cells. Restoring cell-matrix interactions via specific recognition sequences from laminin (IKLLI and IKVAV), promoted viability and insulin secretion of MIN6 insulinoma cells [98]. It has been reported that Laminin-332-rich (also known as laminin-5) extracellular matrix derived from $804 \mathrm{G}$ rat bladder carcinoma cells allowed rat beta-cell spreading, decreased apoptosis and enhanced insulin secretion compared with cells attached on poly-L-lysine [99-102]. Blocking the interaction between $\beta 1$ integrin and laminin-332 resulted in reduced glucose-stimulated insulin secretion, indicating that this specific interaction is involved in cell spreading and insulin secretion [99].

\subsubsection{Fibronectin}

Another major component of the extracellular matrix is fibronectin. It binds various integrins through recognition of the RGD (Arg-Gly-Asp) motif. RGD binding integrins are prevalent within islets and have been associated with strong cell adhesion and spreading. Islets cultured for 48 hours on fibronectin showed improved viability and greater insulin and DNA content than islets cultures without fibronectin. Transplantation of fibronectin-treated islets in rats resulted in lower plasma glucose levels and increased plasma insulin levels [84]. Others reported that adding soluble fibronectin $(10 \mu \mathrm{g} / \mathrm{ml})$ to canine islet suspension cultures preserved integrin expression, increased islet survival and glucose-responsiveness compared to the free floating control condition [103]. Conversely, others have reported reduced survival and function of human beta-cells that were cultured on fibronectin [97, 104]. 


\subsubsection{Combinations of natural ECM proteins}

Many studies use ECM preparations that contain multiple types of ECM molecules, which makes it difficult to study which specific matrix molecules contribute to the positive effect. Several reports describe the incorporation of combinations of ECM proteins in three-dimensional hydrogel cultures. For example, it has been reported that survival of rat pancreatic islets was improved when islets were cultured in collagen type I hydrogel mixed with collagen type III, type IV and laminin [105]. Moreover, Weber et al. showed that incorporation of collagen type IV and laminin together into PEG hydrogels improved survival and function of encapsulated MIN6 insulinoma cells after 10 days of culture, compared to collagen or laminin alone [106]. Davis et al. demonstrated that encapsulation in silk hydrogels with a combination of laminin and collagen IV maintained survival and function of mouse islet in vitro. In addition, they showed that co-encapsulation of laminin and collagen in combination with mouse MSCs resulted in a 3.2-fold increase in insulin secretion [107].

\subsubsection{Synthetic ECM}

In addition to biological ECM compounds, self-assembling peptide nanofibers (SAPNF), a synthetic ECM, has been shown to aid in maintaining human islet morphology and improve islet function in vitro and in vivo when compared to human islets alone or in human fibronectin [108], and might offer a good alternative for use in the clinical setting.

\subsection{D islet morphology and function}

It is often difficult to determine whether the beneficial or adverse effects that are found in vitro are related to specific ECM-binding events or affected by the two- or three-dimensional culture. As described in paragraph 1.4.2, Lucas-clerc et al. demonstrated that long-term culture of human islets embedded in three-dimensional collagen I gels hold their spherical shape and maintained higher glucose-responsiveness when compared to two-dimensional culture on tissue culture plastic [95]. Daoud et al. describe the effects of main ECM components on adhesion, survival and function of human islets. They reported strong islet adhesion on collagen I, collagen IV and fibronectin surfaces and showed that collagen I and IV demonstrate islet spreading and loss of morphology. They showed that islets cultured on fibronectin and laminin maintained their morphology with minimal spreading and showed the highest glucose-responsiveness compared to islets that lost their three-dimensional morphology on collagen-modified surfaces. However stimulation indices were still approximately 1.5 fold lower than freshly isolated islets [109]. Others reported that pancreatic rat islets showed improved viability and function when cultured in threedimensional self-assembling peptide nanofiber hydrogels compared to two-dimensional culture environment (without scaffold) [110]. Rackham et al. demonstrated that a spherical morphology was maintained after co-transplantation of islets with MSCs, whereas islets alone tend to fuse and lose their spherical morphology after transplanta- 
tion underneath the kidney capsule. Co-transplantation produced superior transplantation outcomes with $92 \%$ of recipient mice reverting to normoglycemia, compared to islet-alone grafts (42\%) [111]. These findings suggest that spherical islet shape is associated with islet function and that islet spreading and loss of islet morphology may result in decreased islet function and glucose-responsiveness.

\subsection{Beta-cell interactions with biopolymer films}

Biomaterials can be used to create an artificial transplantation site that can be tailored to provide optimal support and mimic the natural islet microenvironment. To find the best substrate for islet survival and function, Williams et al. studied the interaction of dispersed rat islet cells with a variety of biopolymer films. They demonstrated that laminin coatings in combination with mildly hydrophobic polymers such as low molecular weight PLGA performed well in terms of cell attachment, which was shown to be mediated by E-cadherin, $\beta 1$ integrin and $\beta$-catenin [112]. Mei et al. studied a micro arrayed library of 496 different polymers for islet cell culture. Different combinations of 22 major and minor acrylate monomers with different chemical groups, crosslinking densities and hydrophobicity/hydrophilicity were used to create a large variety of chemically diverse polymers. After precoating with fibronectin (Fn), they studied attachment and insulin expression of rat islet cells. They observed that only a few polymers with distinct characteristics supported islet cell attachment. Aminegroups were shown critical in cell attachment, which is thought to be associated with exposure of certain epitopes of the adsorbed fibronectin [113]. The results suggest that the chemical structure as well as the composition of major and minor monomers are critical in selecting a polymer for biological applications. It needs to be evaluated whether the attached beta-cells are still glucose-responsive in vitro and whether using these biopolymers for islet transplantation could improve glycemia in vivo.

\subsection{Conclusions and recommendations}

When designing islet-containing constructs for transplantation, it is crucial to find the optimal balance between the required cell-cell contacts on one hand, and the optimal mass transport on the other hand. In addition, the potential role of cellular organisation should not be neglected. Although there is no clear evidence for the need of a specific cellular organization in human islets of Langerhans, loss of specific cellular arrangement may on the long-term result in impaired islet function. The studies reviewed here showed that restoring islet-ECM interactions by incorporating ECM proteins in novel scaffolds designs improves survival and function of islets and beta-cells, and could improve transplantation outcome. However, care must be taken when selecting these compounds as some islet-ECM binding interactions have shown to cause unfavourable effects on beta-cell function.

Biomaterials may help to maintain viability and function, and aid in cell aggregate formation. Purified beta-cells and dissociated islet cells require an artificial islet niche for attachment prior to implantation. In these cases, scaffolds could be useful. The 
specific role of biomaterials for intact islets is not entirely clear. Biomaterials can serve as an artificial transplantation site that can be tailored to mimic the natural islet microenvironment and provide optimal support, which could result in enhanced transplantation outcomes. On the other hand, several studies have indicated that islet spreading and loss of spherical islet morphology may adversely affect islet function and glucose-responsiveness. A biopolymer with slight hydrophobic surface that prevents cell attachment would most likely be the best choice for islet tissue engineering. The biomaterial could be enhanced with a combination of natural ECM proteins by biochemical functionalization to provide cell-adhesion points to immobilize the islets while preventing spreading.

To further optimize the biomaterial for type 1 diabetes treatment, constructs could be loaded with soluble factors that are released when stimulated by the external environment after transplantation. For example, islet transplantation may benefit from storage and controlled release of vascular growth factors [114]. In addition, oxygen-generating materials, like the $\mathrm{PDMS}-\mathrm{CaO}_{2}$ disks that have been developed by Pedraza et al. [115], could be incorporated into a three-dimensional islet-containing construct to prevent hypoxia-induced cell death, which could potentially promote islet survival after transplantation. 


\section{References}

1. Pileggi, A., et al., Twenty years of clinical islet transplantation at the Diabetes Research Institute-University of Miami. Clin Transpl, 2004: p. 177-204.

2. Shapiro, A.M., et al., International trial of the Edmonton protocol for islet transplantation. N Engl J Med, 2006. 355(13): p. 1318-30.

3. Tharavanij, T., et al., Improved long-term health-related quality of life after islet transplantation. Transplantation, 2008. 86(9): p. 1161-7.

4. Biarnes, M., et al., Beta-cell death and mass in syngeneically transplanted islets exposed to short- and long-term hyperglycemia. Diabetes, 2002. 51(1): p. 66-72.

5. Davalli, A.M., et al., Vulnerability of islets in the immediate posttransplantation period. Dynamic changes in structure and function. Diabetes, 1996. 45(9): p. 11617.

6. Mattsson, G., et al., Evidence of functional impairment of syngeneically transplanted mouse pancreatic islets retrieved from the liver. Diabetes, 2004. 53(4): p. 948-54.

7. Carlsson, P.O., Influence of microenvironment on engraftment of transplanted beta-cells. Upsala Journal of Medical Sciences, 2011. 116(1): p. 1-7.

8. Johansson, U., et al., Formation of composite endothelial cell-mesenchymal stem cell islets: a novel approach to promote islet revascularization. Diabetes, 2008. 57(9): p. 2393-401.

9. Aguayo-Mazzucato, C. and S. Bonner-Weir, Stem cell therapy for type 1 diabetes mellitus. Nat Rev Endocrinol, 2010. 6(3): p. 139-48.

10. Chhoun, J.M., K.J. Voltzke, and M.T. Firpo, From cell culture to a cure: pancreatic beta-cell replacement strategies for diabetes mellitus. Regen Med, 2012. 7(5): p. $685-95$.

11. Soggia, A., et al., Cell-based therapy of diabetes: What are the new sources of beta cells? Diabetes \& Metabolism, 2011. 37(5): p. 371-375.

12. McCall, M.D., et al., Are stem cells a cure for diabetes? Clin Sci (Lond), 2010. 118(2): p. 87-97. 13. Langer, R. and J.P. Vacanti, Tissue engineering. Science, 1993. 260(5110): p. 920-6.

14. Carvell, M.J., et al., E-cadherin interactions regulate beta-cell proliferation in islet-like structures. Cell Physiol Biochem, 2007. 20(5): p. 617-26.

15. Bosco, D., L. Orci, and P. Meda, Homologous but not heterologous contact increases the insulin secretion of individual pancreatic B-cells. Exp Cell Res, 1989. 184(1): p. $72-80$.

16. Hauge-Evans, A.C., et al., Somatostatin secreted by islet delta-cells fulfills multiple roles as a paracrine regulator of islet function. Diabetes, 2009. 58(2): p. 403-11.

17. Orci, L. and R.H. Unger, Functional subdivision of islets of Langerhans and possible role of D cells. Lancet, 1975. 2(7947): p. 1243-4.

18. Cirulli, V., et al., Expression of neural cell adhesion molecule (N-CAM) in rat islets and its role in islet cell type segregation. J Cell Sci, 1994. 107 ( Pt 6): p. 1429-36.

19. Esni, F., et al., Neural cell adhesion molecule (N-CAM) is required for cell type segregation and normal ultrastructure in pancreatic islets. J Cell Biol, 1999. 144(2): 
p. 325-37.

20. Rouiller, D.G., V. Cirulli, and P.A. Halban, Differences in aggregation properties and levels of the neural cell adhesion molecule (NCAM) between islet cell types. Exp Cell Res, 1990. 191(2): p. 305-12.

21. Gannon, M., et al., Persistent expression of HNF6 in islet endocrine cells causes disrupted islet architecture and loss of beta cell function. Development, 2000. 127(13): p. 2883-95.

22. Bosco, D., et al., Unique arrangement of alpha- and beta-cells in human islets of Langerhans. Diabetes, 2010. 59(5): p. 1202-10.

23. Cabrera, O., et al., The unique cytoarchitecture of human pancreatic islets has implications for islet cell function. Proc Natl Acad Sci U S A, 2006. 103(7): p. 23349.

24. Brissova, M., et al., Assessment of human pancreatic islet architecture and composition by laser scanning confocal microscopy. J Histochem Cytochem, 2005. 53(9): p. $1087-97$.

25. Lin, C.C. and K.S. Anseth, Cell-cell communication mimicry with poly(ethylene glycol) hydrogels for enhancing beta-cell function. Proc Natl Acad Sci U S A, 2011. 108(16): p. 6380-5. 26. Brereton, H.C., et al., Homotypic cell contact enhances insulin but not glucagon secretion. Biochem Biophys Res Commun, 2006. 344(3): p. 995-1000.

27. Hauge-Evans, A.C., et al., Pancreatic beta-cell-to-beta-cell interactions are required for integrated responses to nutrient stimuli: enhanced $\mathrm{Ca} 2+$ and insulin secretory responses of MIN6 pseudoislets. Diabetes, 1999. 48(7): p. 1402-8.

28. Luther, M.J., et al., MIN6 beta-cell-beta-cell interactions influence insulin secretory responses to nutrients and non-nutrients. Biochem Biophys Res Commun, 2006. 343(1): p. 99-104.

29. Hauge-Evans, A.C., et al., Role of adenine nucleotides in insulin secretion from MIN6 pseudoislets. Mol Cell Endocrinol, 2002. 191(2): p. 167-76.

30. Kelly, C., et al., Comparison of insulin release from MIN6 pseudoislets and pancreatic islets of Langerhans reveals importance of homotypic cell interactions. Pancreas, 2010. 39(7): p. 1016-23.

31. Halban, P.A., et al., The possible importance of contact between pancreatic islet cells for the control of insulin release. Endocrinology, 1982. 111(1): p. 86-94.

32. Wojtusciszyn, A., et al., Insulin secretion from human beta cells is heterogeneous and dependent on cell-to-cell contacts. Diabetologia, 2008. 51(10): p. 1843-52.

33. Pipeleers, D., et al., Glucose-induced insulin release depends on functional cooperation between islet cells. Proc Natl Acad Sci U S A, 1982. 79(23): p. 7322-5.

34. Meda, P., et al., Gap junction development is correlated with insulin content in the pancreatic B cell. Science, 1980. 209(4460): p. 1026-8.

35. Dean, P.M. and E.K. Matthews, Electrical activity in pancreatic islet cells. Nature, 1968. 219(5152): p. 389-90.

36. Eddlestone, G.T., et al., Electrical coupling between cells in islets of Langerhans from mouse. J Membr Biol, 1984. 77(1): p. 1-14.

37. Zhang, Q., et al., Cell coupling in mouse pancreatic beta-cells measured in intact islets of Langerhans. Philos Trans A Math Phys Eng Sci, 2008. 366(1880): p. 3503- 
23.

38. Leite, A.R., et al., Co-expression and regulation of connexins 36 and 43 in cultured neonatal rat pancreatic islets. Can J Physiol Pharmacol, 2005. 83(2): p. 142-51.

39. Meda, P., Cx36 involvement in insulin secretion: characteristics and mechanism. Cell Commun Adhes, 2003. 10(4-6): p. 431-5.

40. Serre-Beinier, V., et al., Connexins and secretion. Biol Cell, 2002. 94(7-8): p. 477-92.

41. Bosco, D., D.G. Rouiller, and P.A. Halban, Differential expression of E-cadherin at the surface of rat beta-cells as a marker of functional heterogeneity. J Endocrinol, 2007. 194(1): p. 21-9.

42. Dahl, U., A. Sjodin, and H. Semb, Cadherins regulate aggregation of pancreatic beta-cells in vivo. Development, 1996. 122(9): p. 2895-902.

43. Yamagata, K., et al., Overexpression of dominant-negative mutant hepatocyte nuclear factor-1 alpha in pancreatic beta-cells causes abnormal islet architecture with decreased expression of E-cadherin, reduced beta-cell proliferation, and diabetes. Diabetes, 2002. 51(1): p. 114-23.

44. Moller, C.J., et al., Differential expression of neural cell adhesion molecule and cadherins in pancreatic islets, glucagonomas, and insulinomas. Mol Endocrinol, 1992. 6(8): p. $1332-42$.

45. Rouiller, D.G., V. Cirulli, and P.A. Halban, Uvomorulin mediates calciumdependent aggregation of islet cells, whereas calcium-independent cell adhesion molecules distinguish between islet cell types. Dev Biol, 1991. 148(1): p. 233-42.

46. Beattie, G.M., et al., A novel approach to increase human islet cell mass while preserving beta-cell function. Diabetes, 2002. 51(12): p. 3435-9.

47. Bonner-Weir, S., et al., In vitro cultivation of human islets from expanded ductal tissue. Proc Natl Acad Sci U S A, 2000. 97(14): p. 7999-8004.

48. Oberg-Welsh, C., Long-term culture in matrigel enhances the insulin secretion of fetal porcine islet-like cell clusters in vitro. Pancreas, 2001. 22(2): p. 157-63.

49. Cavallari, G., et al., Rat pancreatic islet size standardization by the "hanging drop" technique. Transplant Proc, 2007. 39(6): p. 2018-20.

50. Cerdan, C., S.H. Hong, and M. Bhatia, Formation and hematopoietic differentiation of human embryoid bodies by suspension and hanging drop cultures. Curr Protoc Stem Cell Biol, 2007. Chapter 1: p. Unit 1D 2.

51. Wang, X. and P. Yang, In vitro differentiation of mouse embryonic stem (mES) cells using the hanging drop method. J Vis Exp, 2008(17).

52. Bernard, A.B., C.C. Lin, and K.S. Anseth, A Microwell Cell Culture Platform for the Aggregation of Pancreatic beta-Cells. Tissue Eng Part C Methods, 2012.

53. Gallego-Perez, D., et al., Micro/nanoscale technologies for the development of hormone-expressing islet-like cell clusters. Biomed Microdevices, 2012. 14(4): p. 779-89.

54. Ramachandran, K., et al., Engineering Islets for Improved Performance by Optimized Reaggregation in a Micromold. Tissue Eng Part A, 2012.

55. Mendelsohn, A.D., et al., Patterning of mono- and multilayered pancreatic betacell clusters. Langmuir, 2010. 26(12): p. 9943-9.

56. Mendelsohn, A.D., et al., Size-controlled insulin secreting cell clusters. Acta Bio- 
mater, 2012.

57. Aumailley, M., et al., A simplified laminin nomenclature. Matrix Biol, 2005. 24(5): p. $326-32$.

58. Saito, T., et al., Reversal of diabetes by the creation of neo-islet tissues into a subcutaneous site using islet cell sheets. Transplantation, 2011. 92(11): p. 1231-6.

59. Shimizu, H., et al., Bioengineering of a functional sheet of islet cells for the treatment of diabetes mellitus. Biomaterials, 2009. 30(30): p. 5943-9.

60. Bonner-Weir, S. and L. Orci, New perspectives on the microvasculature of the islets of Langerhans in the rat. Diabetes, 1982. 31(10): p. 883-9.

61. Henderson, J.R. and M.C. Moss, A morphometric study of the endocrine and exocrine capillaries of the pancreas. Q J Exp Physiol, 1985. 70(3): p. 347-56.

62. Kuroda, M., et al., Colocalization of vascular endothelial growth factor (vascular permeability factor) and insulin in pancreatic islet cells. J Clin Endocrinol Metab, 1995. 80(11): p. 3196-200.

63. Giuliani, M., et al., Central necrosis in isolated hypoxic human pancreatic islets: evidence for postisolation ischemia. Cell Transplant, 2005. 14(1): p. 67-76.

64. Nikolova, G., et al., The vascular basement membrane: a niche for insulin gene expression and Beta cell proliferation. Dev Cell, 2006. 10(3): p. 397-405.

65. Nikolova, G., B. Strilic, and E. Lammert, The vascular niche and its basement membrane. Trends Cell Biol, 2007. 17(1): p. 19-25.

66. Brissova, M., et al., Intraislet endothelial cells contribute to revascularization of transplanted pancreatic islets. Diabetes, 2004. 53(5): p. 1318-25.

67. Li, Y., et al., Combined strategy of endothelial cells coating, Sertoli cells coculture and infusion improves vascularization and rejection protection of islet graft. PLoS One, 2013. 8(2): p. e56696.

68. Coppens, V., et al., Human blood outgrowth endothelial cells improve islet survival and function when co-transplanted in a mouse model of diabetes. Diabetologia, 2013. 56(2): p. 382-90.

69. Berman, D.M., et al., Mesenchymal stem cells enhance allogeneic islet engraftment in nonhuman primates. Diabetes, 2010. 59(10): p. 2558-68.

70. Ding, Y., et al., Mesenchymal stem cells prevent the rejection of fully allogenic islet grafts by the immunosuppressive activity of matrix metalloproteinase-2 and -9 . Diabetes, 2009. 58(8): p. 1797-806.

71. Solari, M.G., et al., Marginal mass islet transplantation with autologous mesenchymal stem cells promotes long-term islet allograft survival and sustained normoglycemia. J Autoimmun, 2009. 32(2): p. 116-24.

72. Lee, R.H., et al., Multipotent stromal cells from human marrow home to and promote repair of pancreatic islets and renal glomeruli in diabetic NOD/scid mice. Proc Natl Acad Sci U S A, 2006. 103(46): p. 17438-43.

73. Fiorina, P., et al., Immunomodulatory function of bone marrow-derived mesenchymal stem cells in experimental autoimmune type 1 diabetes. J Immunol, 2009. 183(2): p. 993-1004.

74. Figliuzzi, M., et al., Bone marrow-derived mesenchymal stem cells improve islet graft function in diabetic rats. Transplant Proc, 2009. 41(5): p. 1797-800.

75. Ito, T., et al., Mesenchymal stem cell and islet co-transplantation promotes graft 
revascularization and function. Transplantation, 2010. 89(12): p. 1438-45.

76. Park, K.S., et al., Trophic molecules derived from human mesenchymal stem cells enhance survival, function, and angiogenesis of isolated islets after transplantation. Transplantation, 2010. 89(5): p. 509-17.

77. Rackham, C.L., et al., Pre-culturing islets with mesenchymal stromal cells using a direct contact configuration is beneficial for transplantation outcome in diabetic mice. Cytotherapy, 2013. 15(4): p. 449-59.

78. De Miguel, M.P., et al., Immunosuppressive properties of mesenchymal stem cells: advances and applications. Curr Mol Med, 2012. 12(5): p. 574-91.

79. Tyndall, A., et al., Immunomodulatory properties of mesenchymal stem cells: a review based on an interdisciplinary meeting held at the Kennedy Institute of Rheumatology Division, London, UK, 31 October 2005. Arthritis Res Ther, 2007. 9(1): p. 301.

80. Spaggiari, G.M., et al., Mesenchymal stem cells inhibit natural killer-cell proliferation, cytotoxicity, and cytokine production: role of indoleamine 2,3-dioxygenase and prostaglandin E2. Blood, 2008. 111(3): p. 1327-33.

81. Nasef, A., et al., Identification of IL-10 and TGF-beta transcripts involved in the inhibition of T-lymphocyte proliferation during cell contact with human mesenchymal stem cells. Gene Expr, 2007. 13(4-5): p. 217-26.

82. Rabinowitz, K.M., et al., Transforming growth factor beta signaling controls activities of human intestinal CD8(+)T suppressor cells. Gastroenterology, 2013. 144(3): p. $601-612$ e1.

83. Choi, S.E., et al., IL-6 protects pancreatic islet beta cells from pro-inflammatory cytokines-induced cell death and functional impairment in vitro and in vivo. Transpl Immunol, 2004. 13(1): p. 43-53.

84. Hamamoto, Y., et al., Beneficial effect of pretreatment of islets with fibronectin on glucose tolerance after islet transplantation. Horm Metab Res, 2003. 35(8): p. 460-5.

85. Selmani, Z., et al., HLA-G is a crucial immunosuppressive molecule secreted by adult human mesenchymal stem cells. Transplantation, 2009. 87(9 Suppl): p. S62-6. 86. Selmani, Z., et al., Human leukocyte antigen-G5 secretion by human mesenchymal stem cells is required to suppress $\mathrm{T}$ lymphocyte and natural killer function and to induce CD4+CD25highFOXP3+ regulatory T cells. Stem Cells, 2008. 26(1): p. $212-22$.

87. Sato, K., et al., Nitric oxide plays a critical role in suppression of T-cell proliferation by mesenchymal stem cells. Blood, 2007. 109(1): p. 228-34.

88. Le Blanc, K., et al., Treatment of severe acute graft-versus-host disease with third party haploidentical mesenchymal stem cells. Lancet, 2004. 363(9419): p. 1439-41.

89. Le Blanc, K. and O. Ringden, Immunomodulation by mesenchymal stem cells and clinical experience. J Intern Med, 2007. 262(5): p. 509-25.

90. Ringden, O., et al., Mesenchymal stem cells for treatment of therapy-resistant graft-versus-host disease. Transplantation, 2006. 81(10): p. 1390-7.

91. Stendahl, J.C., D.B. Kaufman, and S.I. Stupp, Extracellular matrix in pancreatic islets: relevance to scaffold design and transplantation. Cell Transplant, 2009. 18(1): p. 1-12. 
92. Frisch, S.M. and R.A. Screaton, Anoikis mechanisms. Curr Opin Cell Biol, 2001. 13(5): p. 555-62.

93. Rosenberg, L., et al., Structural and functional changes resulting from islet isolation lead to islet cell death. Surgery, 1999. 126(2): p. 393-8.

94. Nagata, N., et al., Evaluation of insulin secretion of isolated rat islets cultured in extracellular matrix. Cell Transplant, 2001. 10(4-5): p. 447-51.

95. Lucas-Clerc, C., et al., Long-term culture of human pancreatic islets in an extracellular matrix: morphological and metabolic effects. Mol Cell Endocrinol, 1993. 94(1): p. 9-20.

96. Edamura, K., et al., Effect of adhesion or collagen molecules on cell attachment, insulin secretion, and glucose responsiveness in the cultured adult porcine endocrine pancreas: a preliminary study. Cell Transplant, 2003. 12(4): p. 439-46.

97. Kaido, T., et al., Impact of defined matrix interactions on insulin production by cultured human beta-cells: effect on insulin content, secretion, and gene transcription. Diabetes, 2006. 55(10): p. 2723-9.

98. Weber, L.M., et al., The effects of cell-matrix interactions on encapsulated betacell function within hydrogels functionalized with matrix-derived adhesive peptides. Biomaterials, 2007. 28(19): p. 3004-11.

99. Parnaud, G., et al., Blockade of beta1 integrin-laminin-5 interaction affects spreading and insulin secretion of rat beta-cells attached on extracellular matrix. Diabetes, 2006. 55(5): p. 1413-20.

100. Bosco, D., et al., Importance of cell-matrix interactions in rat islet beta-cell secretion in vitro: role of alpha6beta1 integrin. Diabetes, 2000. 49(2): p. 233-43.

101. Hammar, E., et al., Extracellular matrix protects pancreatic beta-cells against apoptosis: role of short- and long-term signaling pathways. Diabetes, 2004. 53(8): p. 2034-41.

102. Parnaud, G., et al., Signaling pathways implicated in the stimulation of beta-cell proliferation by extracellular matrix. Mol Endocrinol, 2009. 23(8): p. 1264-71.

103. Wang, R.N. and L. Rosenberg, Maintenance of beta-cell function and survival following islet isolation requires re-establishment of the islet-matrix relationship. J Endocrinol, 1999. 163(2): p. 181-90.

104. Ris, F., et al., Impact of integrin-matrix matching and inhibition of apoptosis on the survival of purified human beta-cells in vitro. Diabetologia, 2002. 45(6): p. 841-50.

105. Nagata, N.A., K. Inoue, and Y. Tabata, Co-culture of extracellular matrix suppresses the cell death of rat pancreatic islets. J Biomater Sci Polym Ed, 2002. 13(5): p. 579-90.

106. Weber, L.M., K.N. Hayda, and K.S. Anseth, Cell-matrix interactions improve beta-cell survival and insulin secretion in three-dimensional culture. Tissue Eng Part A, 2008. 14(12): p. 1959-68.

107. Davis, N.E., et al., Enhanced function of pancreatic islets co-encapsulated with ECM proteins and mesenchymal stromal cells in a silk hydrogel. Biomaterials, 2012. 33(28): p. 6691-7.

108. Navarro-Alvarez, N., et al., Reestablishment of microenvironment is necessary to maintain in vitro and in vivo human islet function. Cell Transplant, 2008. 17(1-2): 
p. 111-9.

109. Daoud, J., et al., The effect of extracellular matrix components on the preservation of human islet function in vitro. Biomaterials, 2010. 31(7): p. 1676-82.

110. Zhao, M., et al., The three-dimensional nanofiber scaffold culture condition improves viability and function of islets. J Biomed Mater Res A, 2010. 94(3): p. 667-72. 111. Rackham, C.L., et al., Co-transplantation of mesenchymal stem cells maintains islet organisation and morphology in mice. Diabetologia, 2011. 54(5): p. 1127-35.

112. Williams, S.J., et al., Adhesion of pancreatic beta cells to biopolymer films. Biopolymers, 2009. 91(8): p. 676-85.

113. Mei, Y., et al., A high throughput micro-array system of polymer surfaces for the manipulation of primary pancreatic islet cells. Biomaterials, 2010. 31(34): p. 8989-95.

114. Stendahl, J.C., et al., Growth factor delivery from self-assembling nanofibers to facilitate islet transplantation. Transplantation, 2008. 86(3): p. 478-81.

115. Pedraza, E., et al., Preventing hypoxia-induced cell death in beta cells and islets via hydrolytically activated, oxygen-generating biomaterials. Proc Natl Acad Sci U S A, 2012. 109(11): p. 4245-50. 



\section{Chapter 3}

\section{Label-free monitoring of human mesenchymal stromal cell differentiation using Raman spectroscopy}

Janneke Hilderink, Cees Otto, Clemens van Blitterswijk, Marcel Karperien and Aart van Apeldoorn 


\begin{abstract}
It is crucial to monitor the phenotypic changes and understand the dynamic interactions that take place during tissue engineering. Whereas conventional techniques often require extensive sample preparation, Raman microspectroscopy enables the non-destructive and label-free characterization of living cells and tissues. In this study, we explored the use of Raman spectroscopy as a non-destructive analysis method to monitor the multilineage potential of hMSCs by performing Raman measurements on live hMSCs that were differentiated into the adipogenic and osteogenic lineage. We used hyperspectral Raman imaging to visualize the formation of lipid droplets and mineralized nodules in adipogenic and osteogenic cultures, respectively. In addition, we studied the effects of aldehyde fixation methods on the Raman fingerprint of hMSCs and showed that fixation affects the vibrational modes of lipids, proteins and nucleic acids. If fixation is required, we recommend to use formaldehyde since this fixative produces a cell spectrum that is most similar to the spectrum of unfixed cells.
\end{abstract}




\subsection{Introduction}

Tissue engineering may provide functional substitutes of native tissues that can serve as physiologically relevant models to study cell function and tissue development, or can be used for implantation purposes. Various cell types have been used for tissue engineering purposes, such as fibroblasts for skin replacement [1] and chondrocytes for cartilage repair [2]. In addition, human mesenchymal stromal cells (hMSCs) have become a popular source for cell-based therapies because of their accessibility for harvesting, their in vitro expansion capacity and their multipotency. These cells express of cell surface markers CD105, CD73 and CD90 and are capable of differentiating into the osteogenic, chondrogenic and adipogenic lineage upon appropriate stimulation [3, 4]. Several studies have reported the use of hMSCs for a broad range of applications and for a variety of tissue types [5-8]. Cells are often combined with biomaterials and growth factors, to support the formation of three-dimensional tissues and aid in more efficient tissue regeneration. Extensive in vitro culturing is usually required to create a construct of relevant size.

To engineer functional tissues for implantation purposes, it is crucial to monitor the phenotypic changes and understand the dynamic interactions that take place as these tissues develop. Techniques to study e.g. cell proliferation and differentiation often require fixation and labeling of the sample. Raman microspectroscopy provides an alternative by enabling the non-destructive and label-free characterization of living cells and tissues under physiological conditions and has been widely used for biological applications [9-12]. This spectroscopic technique is based on the inelastic scattering of monochromatic light [13]. When light interacts with a sample, a small fraction of light (1 in $10^{6}-10^{8}$ photons) is scattered with a different wavelength from the incident light. This shift is specific for the chemical bonds within the sample, providing a so-called 'molecular fingerprint' [14, 15].

The aim of this study was to investigate the feasibility of using Raman spectroscopy to monitor cell behavior during tissue engineering. Differentiation of hMSCs is used here as a model system to explore the use of Raman spectroscopy as a nondestructive analysis method to monitor the multilineage potential of these cells. To study chemical changes that occur during in vitro differentiation of hMSCs, we performed Raman measurements on live hMSCs that were differentiated to the adipogenic and osteogenic lineage, and compared their molecular fingerprints to undifferentiated cells. Conventional staining protocols were used to validate the results obtained with Raman spectroscopy. Raman spectroscopy allows the analysis of live cells without the need for any sample preparations. However, sometimes fixation of the sample might be necessary or favorable, such as when only clinical samples that have already been prepared for histological examination are available. The aim of fixation is to preserve the biochemical and structural integrity of cells and tissues. Commonly used fixatives are aldehydes, such as glutaraldehyde and formaldehyde. We therefore studied the spectral changes that are associated with aldehyde fixation methods and determined their effect on the Raman fingerprint of hMSCs, since small differences in spectra could influence the outcome of statistical analysis. 


\subsection{Materials and methods}

\subsubsection{Cell culture}

Human mesenchymal stromal cells (hMSCs) were cultured in proliferation medium, consisting of basic medium (BM) containing $\alpha$-MEM (Gibco), $10 \%$ fetal bovine serum (FBS, Lonza), $2 \mathrm{mM}$ L-glutamine (Gibco), $0.02 \mathrm{mM}$ ascorbic acid (Sigma), $100 \mathrm{U} / \mathrm{ml}$ penicillin and $100 \mathrm{mg} / \mathrm{ml}$ streptomycin (Gibco) supplemented with $1 \mathrm{ng} / \mathrm{ml} \mathrm{recombi-}$ nant human fibroblast growth factor (bFGF). Cell cultures were maintained at $37^{\circ} \mathrm{C}$ in humidified air containing $5 \%$ carbon dioxide. Medium was refreshed every 3 to 4 days and cells were replated when $80 \%$ confluency was reached.

\subsubsection{Choice of substrate for Raman measurements}

Polystyrene or glass substrates produce a large amount of background that may overwhelm the weaker Raman signal from biological samples. These materials can therefore not be used as a substrate for Raman measurements. To reduce the background signal from the substrate, cells should be grown on Raman transparent substrates such as $\mathrm{CaF}_{2}, \mathrm{MgF}_{2}$ or quartz. In this study, all cell cultures were performed on UVgrade $\mathrm{CaF}_{2}$ slides (Crystan LTD) because of their low background signal in Raman microspectroscopy. Before cell seeding, $\mathrm{CaF}_{2}$ slides were sterilized using $70 \%$ ethanol and coated with $0.01 \%$ poly-L-lysine (Sigma).

\subsubsection{Cell fixation methods}

hMSCs (passage 2) were seeded and allowed to adhere overnight. The next day, cells were washed with PBS and fixed by 30 min incubation in $1 \%$ glutaraldehyde, freshly prepared $4 \%$ formaldehyde, or 10\% neutral-buffered formalin (containing $4 \%$ PFA, stabilized with $1 \%$ methanol). Samples were stored at $4{ }^{\circ} \mathrm{C}$ in PBS until measured.

\subsubsection{Cell differentiation experiments}

To induce osteogenic differentiation, hMSCs (passage 2-3) were seeded at 5000 cells $/ \mathrm{cm}^{2}$ and allowed to adhere overnight in BM. The next day, medium was changed to mineralization medium consisting of BM supplemented with $10 \mathrm{nM}$ dexamethasone (Sigma) and $0.01 \mathrm{M} \beta$-glycerolphosphate. Cultures were maintained for 4 weeks. For adipogenic differentiation, cells were seeded at 25,000 cells $/ \mathrm{cm}^{2}$ and allowed to adhere in BM. When cultures reached $80 \%$ confluency, BM was replaced by adipogenic differentiation medium containing $\alpha$-MEM (Gibco), $10 \%$ fetal bovine serum (FBS, Lonza), $100 \mathrm{U} / \mathrm{ml}$ penicillin, $100 \mathrm{mg} / \mathrm{ml}$ streptomycin (Gibco), $1 \mu \mathrm{M}$ dexamethasone (Sigma), $10 \mu \mathrm{M}$ human insulin, $0.5 \mathrm{mM}$ IBMX and $200 \mu \mathrm{M}$ indomethacin. Adipogenic differentiation cultures were maintained for 2 weeks. As control condition, hMSCs were seeded at 5000 cells $/ \mathrm{cm}^{2}$ and cultured in BM. 

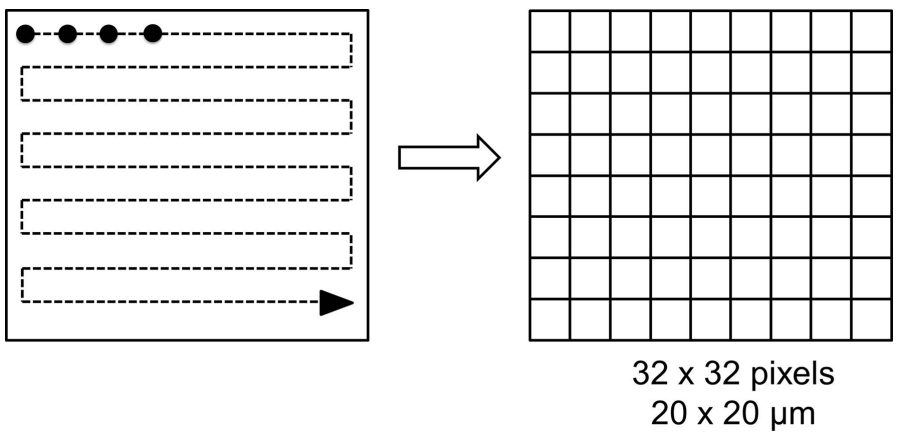

Figure 3.1: Schematic representation of Raman imaging mode. Images were obtained by stepping the laser beam over the $(20 \times 20 \mu \mathrm{m})$ sample area in a $32 \times 32$ raster pattern, with a step size of $0.6 \mu \mathrm{m}$ and an accumulation time of $1 \mathrm{sec} / \mathrm{step}$, resulting a dataset consisting of 1024 spectra per $400 \mu \mathrm{m}^{2}$.

\subsubsection{Histological analysis}

Cells were fixed using $10 \%$ neutral-buffered formalin and rinsed with $\mathrm{dH}_{2} \mathrm{O}$. Intracellular lipid droplets were stained with Oil red O (Sigma) and mineralized matrix was visualized using Alizarin Red S staining (Sigma), according to standard procedures.

\subsubsection{Confocal Raman microspectroscopy}

All Raman measurements were performed on living cells, unless stated otherwise. Briefly, a krypton ion laser (Innova 90-K, Coherent Inc.) emitting at $647.1 \mathrm{~nm}$ at a power of $35 \mathrm{~mW}$ under the objective was used as the excitation source. A $63 \mathrm{x} / 1.0 \mathrm{NA}$ water immersion objective (Zeiss W-plan Apochromat) was used to focus the laser light over the sample. The Raman scattered photons were collected and dispersed on an air-cooled electron-multiplying charge-coupled device (EMCCD; Newton DU970N, Andor Technology). Raman spectra were acquired in either spectral scanning mode or Raman imaging mode. In spectral scanning mode, a single full spectrum is obtained by raster scanning the laser beam over a sample area of $20 \times 20 \mu \mathrm{m}$ for $30 \mathrm{sec}$. Average Raman spectra of cells were acquired in the spectral scanning mode from 10 randomly chosen cells of each cell type. In Raman imaging mode, images were obtained by stepping the laser beam over the sample in a raster pattern while collecting complete spectral information during each step, which is schematically depicted in Figure 3.1. Raman imaging on cells was performed by scanning a $32 \times 32$ raster pattern over a sample area of 20x20 $\mu \mathrm{m}$ with a step size of $0.6 \mu \mathrm{m}$, and an accumulation time of $1 \mathrm{sec} / \mathrm{step}$, resulting in datasets consisting of 1024 spectra per $400 \mu \mathrm{m}^{2}$. 


\subsubsection{Raman data analysis}

Raman spectra were preprocessed, as described previously [16, 17], by: (1) removing cosmic ray events; (2) subtracting camera offset; (3) calibration of the wave number axis; and (4) correction of frequency-dependent transmission. The well-known bandpositions of toluene were used to relate wavenumbers to pixels [18]. The frequencydependent optical detection efciency of the setup was corrected using a tungsten halogen light source (Avalight-HAL; Avantes BV) with a known emission spectrum. The detector-induced etaloning effect was also compensated by this procedure. Noise in the 3D (spatial $\mathrm{x}$ spatial $\mathrm{x}$ spectral dimension) data matrix was reduced by singular value decomposition. Univariate and multivariate analyses were performed over the hyperspectral Raman data as described previously [16, 19]. Univariate analysis was performed by a selection of specific vibrational bands of interest and an integration of the band intensity after local baseline subtraction. Multivariate analysis, involving both principal component analysis (PCA) and hierarchical cluster analysis (HCA) using Wards clustering method, was performed to collectively analyze and compare all cell spectra simultaneously [20, 21]. Data for PCA was preprocessed by autoscaling to the mean of the spectra along the frequency axis. HCA makes use of the scores obtained from the PCA data and was preprocessed with a first derivative Savitsky-Golay algorithm (with seven-point smoothing and quadratic polynomial fit) to minimize small variations in the baseline, and subsequently auto-scaled to the mean of the spectra along the frequency axis. All data manipulations were performed in routines written in MATLAB 7.6 (The MathWorks). HCA and PCA were performed using PLS toolbox (Eigenvectors Research Inc.).

\subsection{Results}

\subsubsection{Effects of fixation on Raman fingerprint of hMSCs}

To determine the effect of standard fixation protocols on the Raman fingerprint of cells, we measured hMSCs that were fixed using various adehyde fixatives. Neutralbuffered formalin (10\%) is a widely used fixative that contains $4 \%$ paraformaldehyde and is stabilized with a small percentage of methanol to slow down the repolymerization and prevent paraformaldehyde precipitation. In addition, a freshly prepared $4 \%$ formaldehyde solution was used as recommended by many protocols, to avoid using methanol-containing formaldehyde. Last, we used glutaraldehyde which is another commonly used aldehyde for tissue fixation.

We characterized spectral changes associated with the use of these fixatives. Average Raman spectra acquired from fixed and unfixed hMSCs are shown in Figure 3.2. Compared to the unfixed control condition, fixation with glutaraldehyde results in Raman fingerprints with additional bands at $875 \mathrm{~cm}^{-1}$ and $1032 \mathrm{~cm}^{-1}$, characteristic for antisymmetric stretching of phosphatidylcholine and $\mathrm{CH}_{2} \mathrm{CH}_{3}$ bending of phospholipids, respectively $[22,23]$. These bands were not visible in the spectra of cells that were fixed in neutral-buffered formalin or fresh formaldehyde solution. In general, we observed that fixation resulted in loss of information in the spectral range 


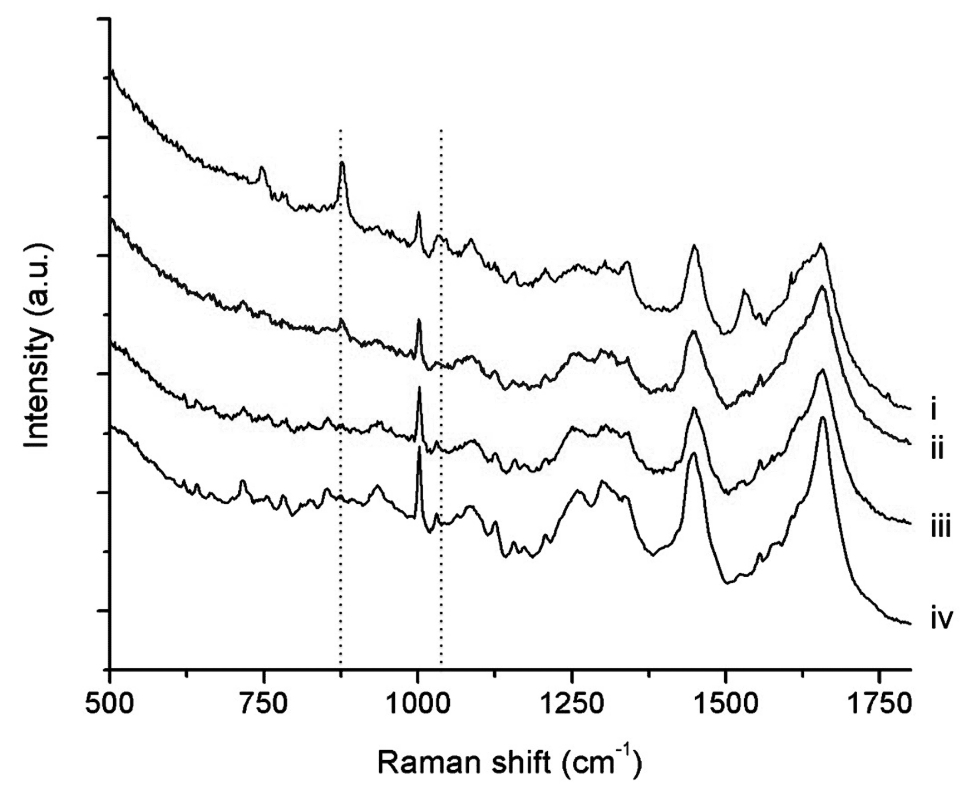

Figure 3.2: Effects of fixation on Raman fingerprint of hMSCs. Average Raman spectra ( $\mathrm{n}=10$ per condition) acquired from hMSCs that were fixed using various fixatives: $1 \%$ glutaradehyde (i), $4 \%$ formaldehyde (ii), $10 \%$ formalin (iii), unfixed (iv). Dashed lines indicate Raman bands that are associated with increased lipid content in the glutaraldehyde fixed cells. Spectra are vertically offset for clear representation.

of $1190-1380 \mathrm{~cm}^{-1}$. Moreover, a decrease in the overall intensity of the Raman bands was observed in the fixed samples compared to the unfixed control. Although all fixation methods used induce small changes in the Raman spectrum of a cell, we observed that cells fixed with formalin or formaldehyde, are most similar to the unfixed cells.

\subsubsection{Raman spectroscopy of adipogenic and osteogenic differentiation of living hMSCs}

Differentiation of hMSCs was induced by several weeks of culture in differentiation medium. To prevent the cells from drying out, samples were kept in PBS solution during Raman measurements. Raman spectral characterization of cells was performed by measuring 10 randomly chosen cells per condition. The average Raman fingerprints of living hMSCs cultured basic, adipogenic and osteogenic differentiation medium are shown in Figure 3.3A. An average background spectrum was acquired from 10 individual Raman spectra that were obtained from the same focusing height adjacent to the cells on the $\mathrm{CaF}_{2}$ substrate. This background spectrum shows a broad band around 1540-1760 $\mathrm{cm}^{-1}$, which corresponds to the $\mathrm{OH}$ bending vibration of water in 
PBS. Since $\mathrm{CaF}_{2}$ has a single strong vibration at $320 \mathrm{~cm}^{-1}$, it does not contribute to the Raman signal in the $600-1800 \mathrm{~cm}^{-1}$ fingerprint region. By subtracting the average background spectrum from the cell spectra, difference spectra were obtained that are free from spectral influences of PBS. The Raman fingerprint of basic hMSCs shows Raman bands originating from DNA $\left(788 \mathrm{~cm}^{-1}\right)$, phenylalanine (1004 and $\left.1032 \mathrm{~cm}^{-1}\right)$, proteins $\left(1126 \mathrm{~cm}^{-1}\right), \mathrm{CH}_{2}$ bending of lipids and proteins (1440-1460 $\left.\mathrm{cm}^{-1}\right)$ and amide-I $\left(1660 \mathrm{~cm}^{-1}\right)$. Raman spectra of adipogenic differentiated hMSCs showed increased bands at 1080, 1264, 1301, 1440, 1655 and $1750 \mathrm{~cm}^{-1}$ compared to the Raman spectrum of the untreated hMSCs. These bands can all be assigned to various vibrational modes of lipids, phospholipids and fatty acids, indicating adipogenic differentiation of the cells and lipid droplet formation. In addition, we studied osteogenic differentiation of these cells after treatments with dexamethasone and $\beta$ glycerolphosphate. When mineralization was induced, the average Raman spectrum showed a strong vibration at $962 \mathrm{~cm}^{-1}$. This band can be assigned to $\nu_{1}$ vibration of phosphates in hydroxyapapite and indicates cell mineralization [24, 25]. Hierarchical cluster analysis (HCA) was applied to the dataset to objectively analyse and compare all cell spectra simultaneously, resulting in the generation of a dendrogram. It can be observed from the dendrogram that the variance between the spectra obtained from cells in adipogenic differentiation medium is much smaller than the variance between an adipogenic cell and a control cell, which resulted in accurate classification of all adipogenic cells in one cluster. However, the spectra of mineralized hMSCs show some overlap with the spectra of untreated control hMSCs. Moreover, the dendrogram shows that the variance between cells from one condition is very small in the basic hMSCs, whereas the spectra of differentiated hMSCs show more variation within one culture condition (Figure 3.3B). Conventional histological methods were used to validate the Raman data. Lipid droplet formation in adipogenic differentiated hMSCs was confirmed by oil red O staining. Alizarin Red staining was performed to validate the formation of mineralized nodules in osteogenic differentiation medium (Figure 3.3C).

\subsubsection{Hyperspectral Raman imaging of hMSC differentiation}

In addition to obtaining average Raman fingerprints of differentiated hMSCs, we performed hyperspectral Raman imaging on these cells to study the distribution of biomolecules within the cells. Brightfield images of adipogenic differentiated hMSCs are shown in Figure 3.4A. Raman imaging was performed on the same sample area and four-level hierarchical cluster analysis of the dataset was performed, resulting in Raman cluster spectra and the corresponding cluster image showing intracellular structures (Figure 3.4B and C). Raman images of specific compounds were made using the spectral information of the fingerprint region. By performing band integrations over selected Raman bands, we constructed images showing the distribution of lipids and phosphates within the cells. Band integration over the $1658 \mathrm{~cm}^{-1}$ lipid band shows intracellular lipid droplets (Figure 3.4D), corresponding to the pattern in Figure $3.4 \mathrm{C}$. Hyperspectral Raman imaging of hMSC mineralization is shown in Figure 3.5. The brightfield image in Figure 3.5A shows mineralized hMSCs. Hierarchical 

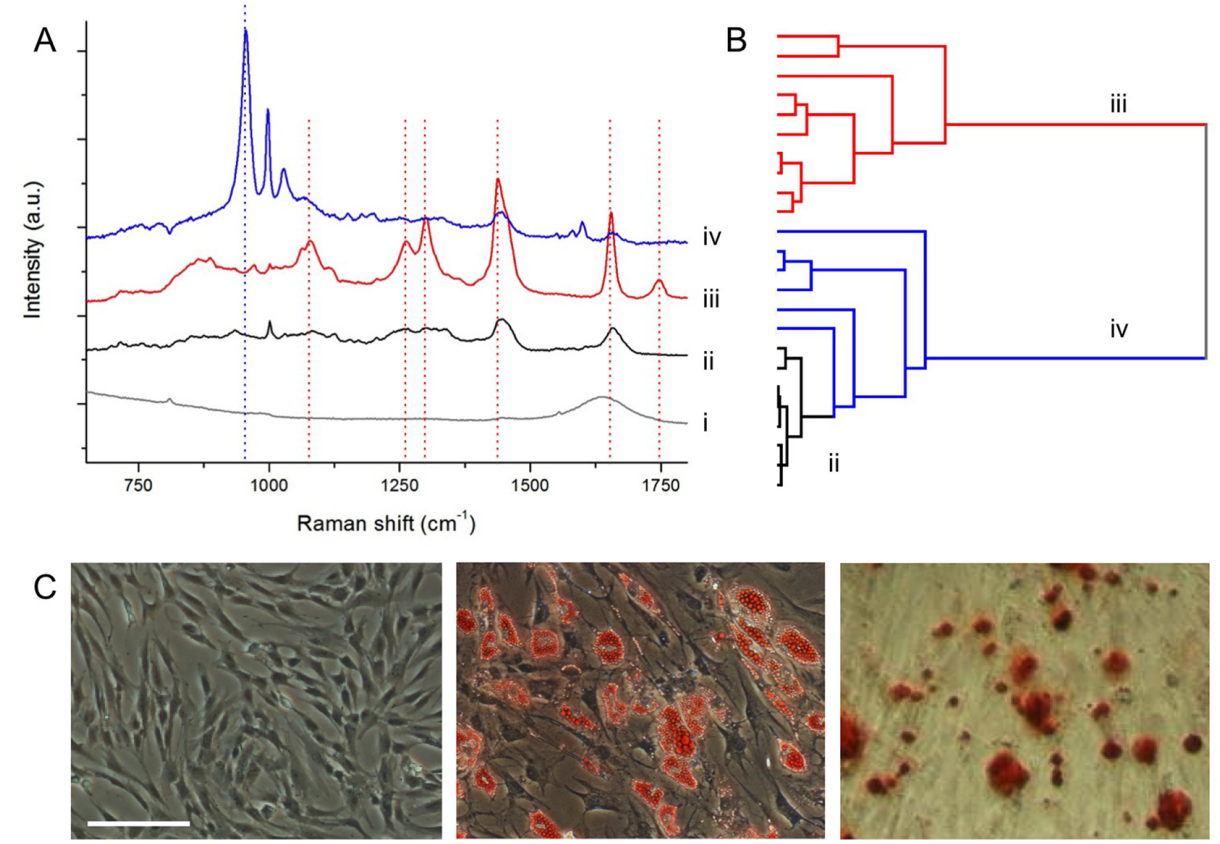

Figure 3.3: Raman spectroscopy of differentiated hMSCs. (A) Average Raman spectra of the fingerprint region $\left(600-1800 \mathrm{~cm}^{-1}\right)$ of PBS (i), Average Raman spectrum of hMSCs cultured in basic medium (ii), adipogenic differentiation medium (iii) or mineralization medium (iv). Each spectrum is obtained by spectral scanning over an area of $20 \times 20 \mu \mathrm{m}$ with an accumulation time of $30 \mathrm{sec}$ and $35 \mathrm{~mW}$ laser power. Cell spectra were corrected by subtracting the PBS spectrum (i), showing background-free cell spectra. Dashed line in blue shows the $962 \mathrm{~cm}^{-1}$ Raman band for $\nu_{1}$ vibration of phosphates, indicating mineralization. Dashed lines in red show characteristic lipid bands, indicating adipogenic differentiation. Spectra are vertically offset for clear representation. (B) Dendrogram of hierarchical cluster analysis classifies the Raman spectra of basic (ii), adipogenic differentiated (iii) and mineralized hMSCs (iv) in separate clusters. (C) Bright-field microscopy images of hMSCs that were cultured for two weeks in basic medium (left), adipogenic differentiation medium stained with Oil Red O (center), or osteogenic differentiation medium stained with Alizarin Red (right) (Courtesy Alizarin Red image: Veronica Monticone). Scale bar indicates $100 \mu \mathrm{m}$. 

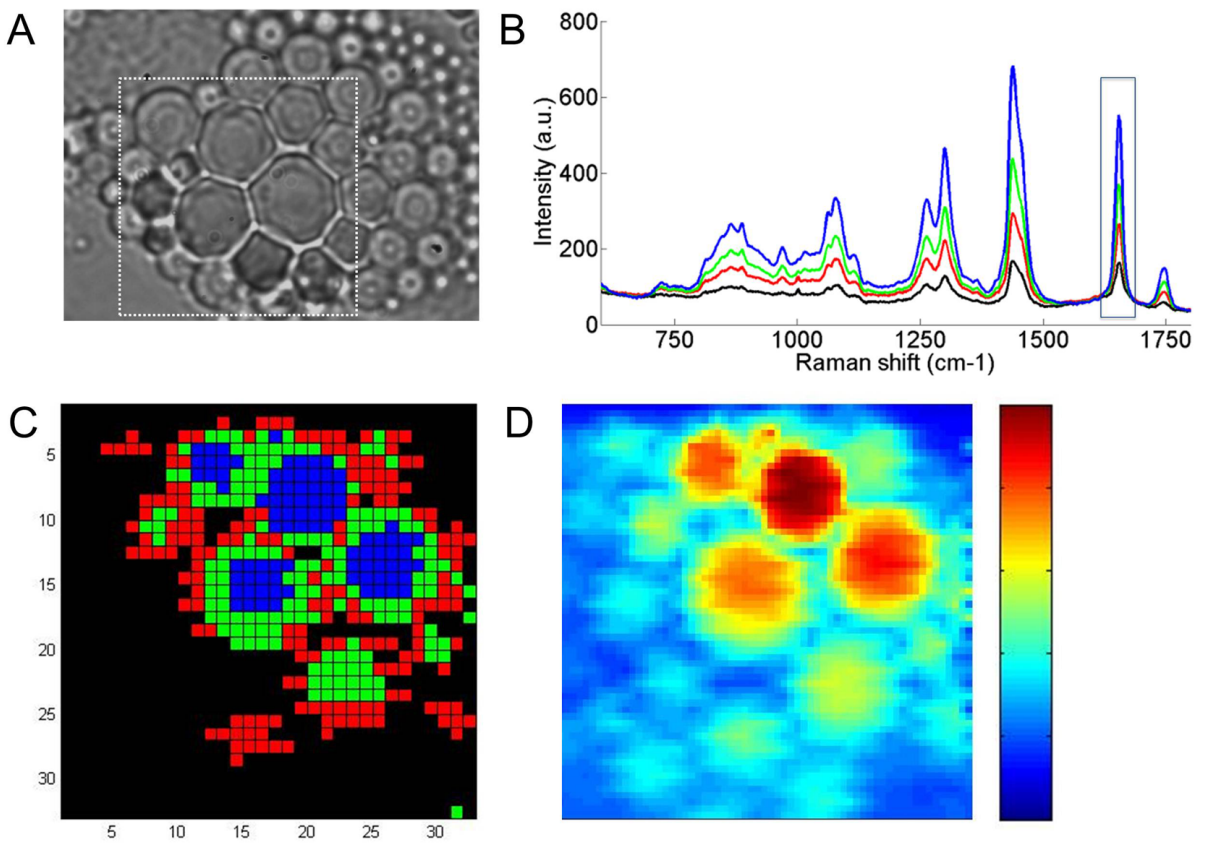

Figure 3.4: Label-free Raman imaging of adipogenic differentiated hMSCs. (A) Bright-field image of adipogenic differentiated hMSCs. (B) Raman cluster spectra and (C) corresponding Raman cluster image (noc=4) acquired by scanning the confocal laser bundle in a $32 \times 32$ raster pattern over a 20x20 $\mu \mathrm{m}$ area (indicated with the dashed square). (D) Univariate Raman image of the $1658 \mathrm{~cm}^{-1}$ band (indicated with rectangle) showing the distribution of unsaturated lipids in the cell.

cluster analysis of the indicated area (dashed square in Figure 3.5A) was performed, resulting in Raman cluster spectra and the corresponding Raman cluster image shown in Figure 3.5B and C. Phosphate distribution was visualized by band integration over the $962 \mathrm{~cm}^{-1}$ Raman band, which was used as a marker for mineralization, displaying mineralized nodules in the cells (Figure 3.5D).

\subsection{Discussion}

We demonstrated the use of Raman spectroscopy to study differentiation of hMSCs without the need for fixation or labelling of the tissue. We showed that Raman spectroscopy enabled the detection of lipids in adipogenic differentiated cell cultures, and phosphates in mineralized cell cultures. Hierarchical cluster analysis was used to classify the individual cell spectra in groups based on their spectral similarities. The smallest variation between cells from one culture condition was observed in the 

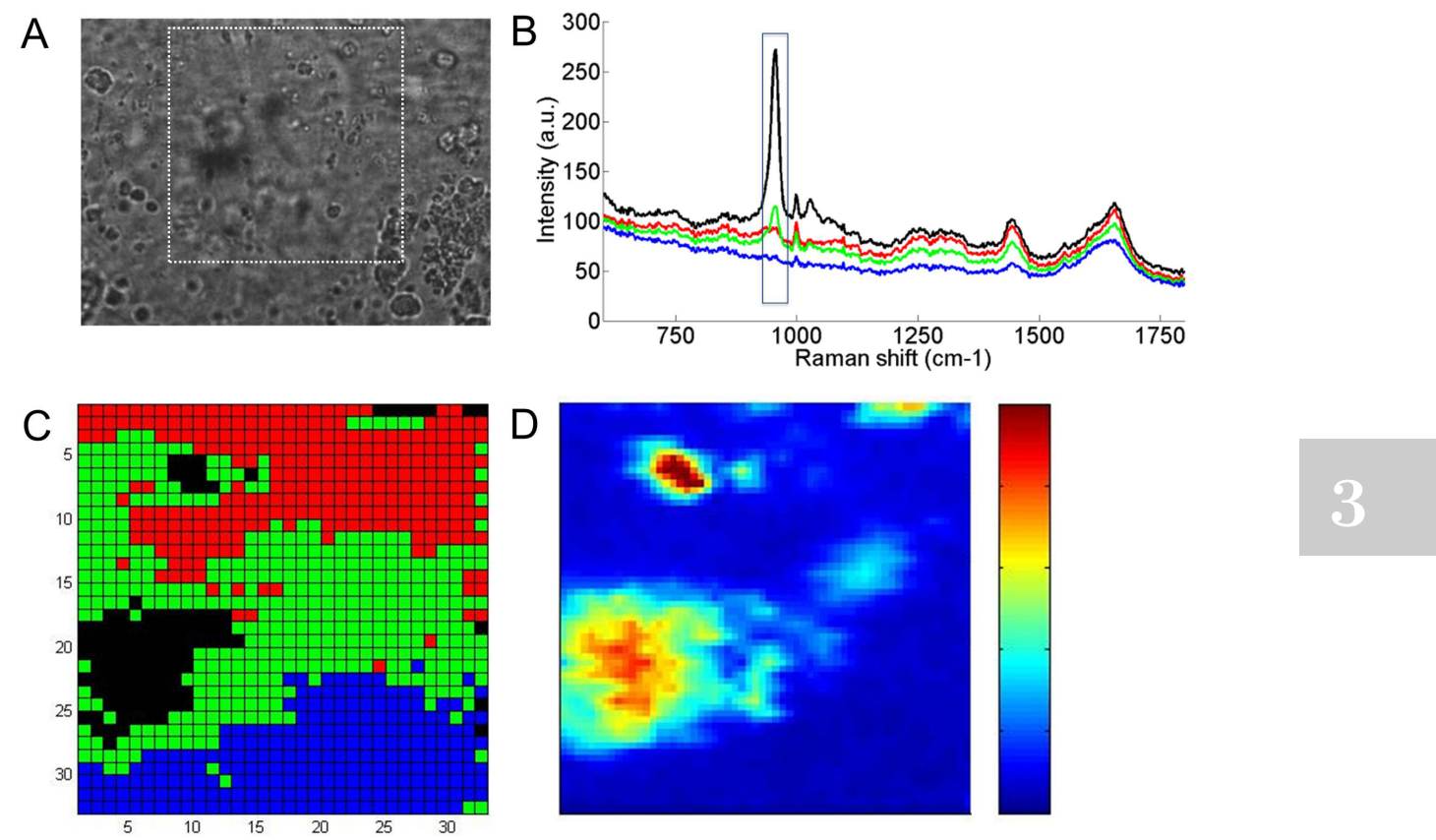

Figure 3.5: Label-free Raman imaging of mineralized hMSCs. (A) Bright-field image of mineralized hMSCs. (B) Raman cluster spectra and (C) corresponding Raman cluster image (noc $=4$ ) acquired by scanning the confocal laser bundle in a $32 \times 32$ raster pattern over a 20x20 $\mu \mathrm{m}$ area (indicated with the dashed square). (D) Univariate Raman image of the $962 \mathrm{~cm}^{-1}$ band (indicated with rectangle) showing the distribution of phosphate in the cell, representing the mineralized nodules.

untreated control cells. Larger variation was observed between the spectra of cells that were cultured in adipogenic or osteogenic differentiation medium, which may indicate incomplete or inefficient differentiation. Moreover, the dendrogram shows some overlap between the mineralized and control spectra which shows that some of the randomly chosen spots that were measured did not contain mineralized nodules and have Raman fingerprints that are similar to undifferentiated hMSCs. In this study, we measured the samples after several weeks of culture in either adipogenic or differentiation medium. However, Raman spectroscopy allows the early detection of cell differentiation markers within the first few days of differentiation. For example, Moody et al. demonstrated the use of surface-enhanced Raman spectroscopy (SERS) to detect lipid production in human-adipose derived stem cells as early as one day after the onset of adipogenesis [26]. In addition, Raman spectroscopic monitoring of stem cell mineralization has been reported between 7 and 28 days of culture in osteogenic differentiation medium [27, 28]. However, these studies only show averaged Raman spectra of the differentiated samples and do not use hyperspectral Raman imaging to 
visualize the intracellular lipid and phosphate distributions.

Fixation is an important tool in biological and medical laboratories, allowing the preservation of biological samples for further examination or transport. Aldehydes, such as glutaraldehyde and formaldehyde, are commonly used fixatives that react with primary and secondary amine groups of proteins, introducing cross-links involving hydroxymethylene bridges $[29,30]$. We determined the effect of standard fixation methods on the Raman fingerprint of cells. Human mesenchymal stem cells were fixed using various aldehyde fixatives and measured using Raman spectroscopy. Fixation resulted in a reduction of overall signal intensity, which is consistent with previous reports and is indicative of denaturation of intracellular proteins and lipids, resulting in an overall decrease of sample volume and loss of protein conformation integrity [31, 32]. The overall reduction in signal intensity may hinder the analysis in case of weak Raman spectra or less sensitive detectors. Moreover, we found enhanced phospholipid content in the fixed cultures, which is related to stress conditions of the cells [33]. Possibly, the formation of phospholipids is induced as a stress response to fixation. The strongest changes in Raman signal were found in the glutaraldehyde-fixed samples. This may be explained by the fact that glutaraldehyde is a dialdehyde, having two aldehyde groups on the molecule, which makes it a stronger protein crosslinker than the monoaldehyde formaldehyde. Moreover, glutaraldehydes are bigger and penetrate slower than formaldehydes, which causes causes extraction of soluble antigens and modification of the structure. Since glutaraldehyde molecules contains two aldehyde groups, they are stronger protein crosslinkers than formaldehyde [34]. Since spectral changes occur after fixation, which may have consequences for the interpretation of biochemical processes within fixed cells, cells and tissues are preferably measured unfixed to best reflect the natural state of the sample. However, when fixed samples need to be analyzed, the fixative should be carefully chosen. Our findings indicate that neutral-buffered formalin and freshly prepared formaldehyde appear to be a better choice for use in combination with Raman spectroscopy than glutaraldehyde. This is in accordance with previous work by Chan et al. who found that formaldehyde fixation induced less changes than other fixation methods [35]. These results highlight the importance of selecting the appropriate fixative for Raman spectroscopy studies to obtain both sensitive and reproducible results.

\subsection{Conclusion}

We showed the use of Raman spectroscopic for the label-free characterization of fixed and living human mesenchymal stromal cells in two-dimensional cell cultures. We observed that fixation affects the vibrational modes of lipids, proteins and nucleic acids. Our findings indicate that formaldehyde fixation best preserves cellular integrity and produces a cell spectrum that is most similar to the spectrum of unfixed cells. Raman measurements on differentiated hMSCs showed increased lipid content after adipogenic differentiation and increased phosphate vibrations in mineralized cultures. We performed hyperspectral Raman imaging to show lipid and phosphate distributions within the cell, which allows monitoring of formation of lipid droplets 
during adipogenesis and mineralized nodules during cell mineralization. Adequate monitoring of molecular changes in living hMSCs during in vitro differentiation in a non-destructive and label-free manner may help to efficiently differentiate pluripotent stem cells towards desired phenotypes and will help to obtain the optimal tissueengineered construct. 


\section{References}

1. Chen, G., et al., Culturing of skin fibroblasts in a thin PLGA-collagen hybrid mesh. Biomaterials, 2005. 26(15): p. 2559-66.

2. Brittberg, M., et al., Treatment of deep cartilage defects in the knee with autologous chondrocyte transplantation. N Engl J Med, 1994. 331(14): p. 889-95.

3. Pittenger, M.F., et al., Multilineage potential of adult human mesenchymal stem cells. Science, 1999. 284(5411): p. 143-7.

4. Dominici, M., et al., Minimal criteria for defining multipotent mesenchymal stromal cells. The International Society for Cellular Therapy position statement. Cytotherapy, 2006. 8(4): p. 315-7.

5. Quarto, R., et al., Repair of large bone defects with the use of autologous bone marrow stromal cells. N Engl J Med, 2001. 344(5): p. 385-6.

6. Shin, L. and D.A. Peterson, Human mesenchymal stem cell grafts enhance normal and impaired wound healing by recruiting existing endogenous tissue stem/progenitor cells. Stem Cells Transl Med, 2013. 2(1): p. 33-42.

7. Diduch, D.R., et al., Marrow stromal cells embedded in alginate for repair of osteochondral defects. Arthroscopy, 2000. 16(6): p. 571-7.

8. Badiavas, E.V. and V. Falanga, Treatment of chronic wounds with bone marrowderived cells. Arch Dermatol, 2003. 139(4): p. 510-6.

9. Notingher, I. and L.L. Hench, Raman microspectroscopy: a noninvasive tool for studies of individual living cells in vitro. Expert Rev Med Devices, 2006. 3(2): p. 215-34.

10. Swain, R.J. and M.M. Stevens, Raman microspectroscopy for non-invasive biochemical analysis of single cells. Biochem Soc Trans, 2007. 35(Pt 3): p. 544-9.

11. Chan, J.W. and D.K. Lieu, Label-free biochemical characterization of stem cells using vibrational spectroscopy. J Biophotonics, 2009. 2(11): p. 656-68.

12. Chan, J.W., et al., Label-free separation of human embryonic stem cells and their cardiac derivatives using Raman spectroscopy. Anal Chem, 2009. 81(4): p. 1324-31. 13. Raman, C.V. and K.S. Krishnan, A new type of secondary radiation (Reprinted from Nature, vol 121, pg 501-502, 1928). Current Science, 1998. 74(4): p. 381-381.

14. Mariani, M.M., P.J. Day, and V. Deckert, Applications of modern micro-Raman spectroscopy for cell analyses. Integr Biol (Camb), 2010. 2(2-3): p. 94-101.

15. Ellis, D.I. and R. Goodacre, Metabolic fingerprinting in disease diagnosis: biomedical applications of infrared and Raman spectroscopy. Analyst, 2006. 131(8): p. 87585 .

16. Uzunbajakava, N., et al., Nonresonant confocal Raman imaging of DNA and protein distribution in apoptotic cells. Biophys J, 2003. 84(6): p. 3968-81.

17. Pully, V.V. and C. Otto, The intensity of the $1602 \mathrm{~cm}^{-1}$ band in human cells is related to mitochondrial activity. Journal of Raman Spectroscopy, 2009. 40(5): p. 473-475.

18. Jue, T., Biomedical applications of biophysics. Handbook of modern biophysics. 2010, New York: Humana Press. x, 237 p.

19. van Manen, H.J., et al., Single-cell Raman and fluorescence microscopy reveal the association of lipid bodies with phagosomes in leukocytes. Proc Natl Acad Sci U S 
A, 2005. 102(29): p. 10159-64.

20. Hervada-Sala, C. and E. Jarauta-Bragulat, A program to perform Ward's clustering method on several regionalized variables. Computers \& Geosciences, 2004. 30(8): p. 881-886.

21. Ward, J.H., Hierarchical Grouping to Optimize an Objective Function. Journal of the American Statistical Association, 1963. 58(301): p. 236.

22. Huang, Z., et al., Near-infrared Raman spectroscopy for optical diagnosis of lung cancer. Int J Cancer, 2003. 107(6): p. 1047-52.

23. Krafft, C., et al., Near infrared Raman spectra of human brain lipids. Spectrochim Acta A Mol Biomol Spectrosc, 2005. 61(7): p. 1529-35.

24. Silveira, L., Jr., et al., Correlation between near-infrared Raman spectroscopy and the histopathological analysis of atherosclerosis in human coronary arteries. Lasers Surg Med, 2002. 30(4): p. 290-7.

25. Timlin, J.A., et al., Spatial distribution of phosphate species in mature and newly generated Mammalian bone by hyperspectral Raman imaging. J Biomed Opt, 1999. 4(1): p. 28-34.

26. Moody, B., et al., In situ monitoring of adipogenesis with human-adipose-derived stem cells using surface-enhanced Raman spectroscopy. Appl Spectrosc, 2010. 64(11): p. 1227-33.

27. Gentleman, E., et al., Comparative materials differences revealed in engineered bone as a function of cell-specific differentiation. Nat Mater, 2009. 8(9): p. 763-70.

28. McManus, L.L., et al., Raman spectroscopic monitoring of the osteogenic differentiation of human mesenchymal stem cells. Analyst, 2011. 136(12): p. 2471-81.

29. Helander, K.G., Kinetic studies of formaldehyde binding in tissue. Biotech Histochem, 1994. 69(3): p. 177-9.

30. Werner, M., et al., Effect of formalin tissue fixation and processing on immunohistochemistry. Am J Surg Pathol, 2000. 24(7): p. 1016-9.

31. Huang, Z., et al., Effect of formalin fixation on the near-infrared Raman spectroscopy of normal and cancerous human bronchial tissues. Int J Oncol, 2003. 23(3): p. 649-55.

32. Kniggendorf, A.K., T.W. Gaul, and M. Meinhardt-Wollweber, Effects of ethanol, formaldehyde, and gentle heat fixation in confocal resonance Raman microscopy of purple nonsulfur bacteria. Microsc Res Tech, 2011. 74(2): p. 177-83.

33. Krafft, C., et al., Studies on stress-induced changes at the subcellular level by Raman microspectroscopic mapping. Anal Chem, 2006. 78(13): p. 4424-9.

34. Hassell, J. and A.R. Hand, Tissue fixation with diimidoesters as an alternative to aldehydes. I. Comparison of cross-linking and ultrastructure obtained with dimethylsuberimidate and glutaraldehyde. J Histochem Cytochem, 1974. 22(4): p. 223-9.

35. Chan, J.W., D.S. Taylor, and D.L. Thompson, The effect of cell fixation on the discrimination of normal and leukemia cells with laser tweezers Raman spectroscopy. Biopolymers, 2009. 91(2): p. 132-9. 



\section{Chapter 4}

\section{Label-free detection of insulin and glucagon within human islets of Langerhans using Raman spectroscopy}

Janneke Hilderink, Cees Otto, Kees Slump, Aufried Lenferink, Marten Engelse, Clemens van Blitterswijk, Eelco de Koning, Marcel Karperien, Aart van Apeldoorn 


\begin{abstract}
Intrahepatic transplantation of donor islets of Langerhans is a promising therapy for patients with type 1 diabetes. It is of critical importance to accurately monitor islet quality before transplantation, which is currently done by standard histological methods that are performed off-line and require extensive sample preparation. As an alternative, we propose Raman spectroscopy which is a non-destructive and label-free technique that allows continuous real-time monitoring of the tissue to study biological changes as they occur. By performing Raman spectroscopic measurements on purified insulin and glucagon, we showed that the $520 \mathrm{~cm}^{-1}$ band assigned to disulfide bridges in insulin, and the $1552 \mathrm{~cm}^{-1}$ band assigned to tryptophan in glucagon are mutually exclusive and could therefore be used as indirect markers for the label-free distinction between both hormones. High-resolution hyperspectral Raman imaging for these specific bands showed the distribution of disulfide bridges and tryptophan at sub-micrometer scale, which correlated with the location of insulin and glucagon as revealed by conventional immunohistochemistry. As a measure for this correlation, quantitative analysis was performed comparing the Raman images with the fluorescence images, resulting in Dice coefficients (ranging between 0 and 1) of 0.36 for insulin and 0.19 for glucagon. Although the use of separate microscope systems with different spatial resolution and the use of indirect Raman markers cause some image mismatch, our findings indicate that Raman bands for disulfide bridges and tryptophan can be used as distinctive markers for the label-free detection of insulin and glucagon in human islets of Langerhans.
\end{abstract}




\subsection{Introduction}

Type 1 diabetes is a chronic disease that is characterized by uncontrollable hyperglycemia, caused by the autoimmune destruction of beta-cells. This results in loss of insulin production, requiring patients to self-administer exogenous insulin daily to control blood sugar levels. Type 1 diabetes affects up to 20 million people worldwide [1]. The annual incidence rate of juvenile (age $<15$ ) type 1 diabetes varies globally, from less than 1/100,000 in most Asian countries to 37/100,000 in certain areas of Europe, and this number is predicted to rise rapidly in the coming years [2-4]. Over time, diabetes can damage the heart, blood vessels, eyes, kidney and nerves, increasing the risk of developing life-threatening diseases such as heart disease, stroke, and kidney failure [5]. Consequently, diabetes and its complications have a significantly adverse economic impact [6]. Type 1 diabetes patients who suffer from severe hypoglycemia unawareness upon daily injections of insulin, or patients who have had a kidney transplant and take immunosuppressant drugs, benefit from intrahepatic transplantation of donor islets of Langerhans as an alternative to whole pancreas transplantation. In this procedure, purified islets extracted from donor pancreata are infused into the portal vein of the patients liver [7]. Although the initial clinical results are promising, only a minority (approximately 10\%) of the patients were insulin-independent five years after treatment $[8,9]$. The need for ongoing immunosuppressive therapy and the scarcity of donor islets have limited its widespread clinical use.

To ensure successful transplantation, it is crucial to accurately assess critical parameters such as beta-cell mass and viability [10, 11]. Conventional methods to characterize the transplant include staining with dithizone (diphenylthiocarbazone, DTZ) to determine islet purity, live/dead assays to assess cell viability, immunohistochemistry to locate insulin and glucagon, and glucose-induced-insulin-release-test (GIIST) to assess islet function. These methods are invasive, requiring sample preparation and labeling, which prohibits real-time monitoring of the tissue. Other studies have shown non-invasive in vivo monitoring of beta-cells and islets using MRI [12], bioluminescence [13] and nuclear imaging [14]. However, the spatial resolution of these methods is usually limited, which does not allow imaging at the individual cell level.

As an alternative, we propose the use of Raman spectroscopy for the non-destructive and label-free characterization of islets of Langerhans. Raman spectroscopy is an analytical technique that is based on the inelastic scattering of monochromatic light [15]. Upon interaction with the sample, a small fraction of the light ( 1 in $10^{6}-10^{8}$ photons) is emitted with a different wavelength from the incident light. This wavelength shift is specific for the chemical bonds within the sample, providing a fingerprint of its entire molecular composition [16]. Raman spectroscopy enables characterization of living cells and tissues under physiological conditions, and is widely used in biological applications [17-20]. Rong et al. demonstrated the real-time monitoring of single rat pancreatic beta-cells using Raman microspectroscopy [21]. Moreover, Raman and infrared spectroscopy have been used for diagnosis of various diseases, including type 1 diabetes [22, 23]. Using pattern-recognition methods, metabolic fingerprints of human serum samples were correlated to disease state [24]. At present, no spectroscopic measurements of human pancreatic islets have yet been reported. This study 
demonstrates the feasibility of using Raman microspectroscopy to characterize islets of Langerhans intended for transplantation in patients with type 1 diabetes.

\subsection{Materials and methods}

\subsubsection{Cell culture}

MIN6-B1 mouse insulinoma cells (kindly provided by Dr. P. Halban, University Medical Center, Geneva, Switzerland) [25] were cultured in high-glucose DMEM with 2.5 mM L-glutamine (Invitrogen) supplemented with 10\% FBS, $100 \mathrm{U} / \mathrm{ml}$ streptomycin, $100 \mu \mathrm{g} / \mathrm{ml}$ penicillin and $70 \mu \mathrm{M}$ freshly added beta-mercaptoethanol. INS-1E rat insulinoma cells (kindly provided by Dr. B. Guigas, LUMC, Leiden, The Netherlands and Dr. P. Maechler, University Medical Center, Geneva, Switzerland) [26] were cultured in RPMI with $2.05 \mathrm{mM}$ L-glutamine (Invitrogen) supplemented with $5 \% \mathrm{FBS}$, $100 \mathrm{U} / \mathrm{ml}$ streptomycin, $100 \mu \mathrm{g} / \mathrm{ml}$ penicillin, $10 \mathrm{mM}$ HEPES, $1 \mathrm{mM}$ sodium pyruvate, $50 \mu \mathrm{M}$ freshly added beta-mercaptoethanol. $\alpha \mathrm{TC} 1-6$ rat alpha-cells (ATCC, Manassas, USA) were cultured in high-glucose DMEM with 2.5mM L-glutamine (Invitrogen) supplemented with $10 \% \mathrm{FBS}, 100 \mathrm{U} / \mathrm{ml}$ streptomycin, $100 \mu \mathrm{g} / \mathrm{ml}$ penicillin, $15 \mathrm{mM}$ HEPES, $1 \mathrm{mM}$ sodium pyruvate, $0.1 \mathrm{mM}$ non-essential amino acids, $0.02 \%$ bovine serum albumin. Cell cultures were maintained at $37^{\circ} \mathrm{C}$ in humidified air containing $5 \% \mathrm{CO}_{2}$. Medium was refreshed every 3 to 4 days and cells were replated when $80 \%$ confluency was reached.

\subsubsection{Human islet culture}

Human cadaveric donor pancreata (provided by the Leiden University Medical Center, Leiden, The Netherlands) were procured through a multi-organ donor program. Tissue samples from the pancreata were used in the study if research consent was present and pancreata could not be used in clinical beta-cell therapy programs according to national laws. Islets were dispersed into single cells by adding $0.025 \%$ trypsin solution containing $10 \mu \mathrm{g} / \mathrm{ml}$ DNase (Pulmozyme, Genentech) and seeded onto agarose microwells for controlled cell aggregation. Intact islets and human islet cell aggregates were cultured in CMRL 1066 medium (5.5 mM glucose) (Mediatech) supplemented with $10 \%$ FCS, $20 \mu \mathrm{g} / \mathrm{ml}$ ciprofloxacin, $50 \mu \mathrm{g} / \mathrm{ml}$ gentamycin, $2 \mathrm{mM}$ L-glutamin, $0.25 \mu \mathrm{g} / \mathrm{ml}$ fungizone, $10 \mathrm{mM}$ HEPES and $1.2 \mathrm{mg} / \mathrm{ml}$ nicotinamide. Cell cultures were maintained at $37^{\circ} \mathrm{C}$ in a $5 \% \mathrm{CO}_{2}$ humidified atmosphere. Medium was refreshed every 3 to 4 days.

\subsubsection{Immunohistochemistry}

To visualize insulin and glucagon, human islets were fixed in PBS containing $4 \%(\mathrm{w} / \mathrm{v})$ paraformaldehyde, incubated overnight in $20 \%$ sucrose at $4{ }^{\circ} \mathrm{C}$, embedded in cryomatrix (Thermo Scientific), and sectioned $(8 \mu \mathrm{m})$ using a cryotome (Shandon). Blocking was done with $0.1 \%(\mathrm{w} / \mathrm{v})$ normal donkey serum/PBS for 1 hour and antibodies were 
diluted in 1\% lamb serum/PBS. Primary antibodies used were: 1:100 rabbit-antiglucagon (Vector Labs) incubated overnight at $4{ }^{\circ} \mathrm{C}$ and 1:200 guinea pig-anti-insulin (ABCAM) incubated for 1.5 hours at $21^{\circ} \mathrm{C}$. Secondary antibodies used were: 1:200 biotin donkey anti-rabbit (Jackson ImmunoResearch), 1:200 streptavidin-Alexa488 (Invitrogen), 1:400 rhodamine donkey anti-guinea pig (Jackson ImmunoResearch), all incubated for 1 hour at $21^{\circ} \mathrm{C}$. Counterstaining was performed with $1 \mu \mathrm{g} / \mathrm{ml} \mathrm{4}-6$ diamidino-2-phenylindole (DAPI). Fluorescence was visualized using a Nikon Eclipse E600 microscope.

\subsubsection{Confocal Raman microspectroscopy}

UV-grade calcium fluoride $\left(\mathrm{CaF}_{2}\right)$ slides (Crystan LTD) were used as sample substrates, because of their low background signal. Purified human recombinant insulin and synthetic glucagon (Sigma), both in powder form, were placed on $\mathrm{CaF}_{2}$ slides. For cells and islet preparations, $\mathrm{CaF}_{2}$ slides were first sterilized using $70 \%$ ethanol and coated with $0.01 \%$ poly-L-lysine (Sigma). INS-1E, $\alpha$ TC6 and MIN6 cells were seeded on coated $\mathrm{CaF}_{2}$ slides at 30,000 cells $/ \mathrm{cm}^{2}$, allowed to attach overnight, fixed using 10\% buffered formalin, and kept in PBS. Cryosections of human islets were placed on coated $\mathrm{CaF}_{2}$ slides. Subsequently, slides were washed in demiwater and air-dried. Raman spectra were acquired using a confocal Raman microspectrometer, similar to the setup described previously [27]. Briefly, a krypton ion laser (Innova 90-K, Coherent Inc.) emitting at $647.1 \mathrm{~nm}$ at a power of $35 \mathrm{~mW}$ under the objective was used as the excitation source. A $63 \mathrm{x} / 1.0 \mathrm{NA}$ water immersion objective (Zeiss W-plan Apochromat) or a 40x/0.75 NA objective (Olympus UPFLN) was used to focus the laser light over the sample. The Raman scattered photons were collected and dispersed on an air-cooled electron-multiplying charge-coupled device (EMCCD; Newton DU-970N, Andor Technology). Raman spectra were acquired in 'Raman imaging mode', in which images were obtained by stepping the laser beam over the sample in a raster pattern, while collecting complete spectral information during each step. Average Raman fingerprints of the single cells were obtained by scanning a $32 \times 32$ raster pattern over a sample area of $20 \times 20 \mu \mathrm{m}$ with a step size of $0.6 \mu \mathrm{m}$ and an accumulation time of $0.5 \mathrm{~s} / \mathrm{step}$, resulting in datasets consisting of 1024 spectra per $400 \mu \mathrm{m}^{2}$ encompassing a single cell. Three-level cluster analysis was performed to separate the spectra corresponding to the cytoplasm and the spectra corresponding to the cell nucleus from the background spectra. Spectral data from 5 randomly chosen cells was averaged. Raman imaging on beta-cells was performed by scanning a $64 \times 64$ raster pattern over a sample area of $20 \times 20 \mu \mathrm{m}$ with a step size of $0.3 \mu \mathrm{m}$, and an accumulation time of 1s/step. Raman imaging on human islet sections was performed by making $16(4 \times 4)$ subsequent scans, each consisting of a 16x16 raster pattern over an area of $30 \times 30 \mu \mathrm{m}$ with a step size of $1.88 \mu \mathrm{m}$ and an accumulation time of $0.5 \mathrm{~s} / \mathrm{step}$. The scans were made exactly $30 \mu \mathrm{m}$ from each other by using a Kleindiek LT6820 microscope substage controlled by a Kleindiek NanoControl (Kleindiek Nanotechnik, Reutlingen, Germany). The spectral data of the scans were then combined (using MATLAB 7.6, The MathWorks) in one large data matrix consisting of 4096 spectra (covering a total sample area of $120 \times 120 \mu \mathrm{m}$ ) on which further data analysis was 
performed. The stitching process was validated using polystyrene latex microspheres of $5 \mu \mathrm{m}$ in diameter. Multiple clusters of these microspheres were imaged in 'Raman imaging mode', after which datasets were combined in MATLAB to form one larger image (Figure 4.1). We have previously reported this image-stitching method for label-free analysis of fetal femur cartilage [26]. High-resolution Raman imaging on subparts of the islet preparations were performed by scanning a $32 \times 32$ raster pattern over a sample area of 30x30 $\mu \mathrm{m}$ with a step size of $0.94 \mu \mathrm{m}$ and an accumulation time of $1 \mathrm{~s} / \mathrm{step}$.

\subsubsection{Raman data analysis}

Raman spectra were preprocessed, as described previously [28, 29], by: (1) removing cosmic ray events; (2) subtracting camera offset; (3) calibration of the wave number axis; and (4) correction of frequency-dependent transmission. The well-known bandpositions of toluene were used to relate wavenumbers to pixels [30]. The frequencydependent optical detection efciency of the setup was corrected using a tungsten halogen light source (Avalight-HAL; Avantes BV) with a known emission spectrum. The detector-induced etaloning effect was also compensated by this procedure. Noise in the 3D (spatial x spatial x spectral dimension) data matrix was reduced by singular value decomposition. Univariate and multivariate analyses were performed over the hyperspectral Raman data as described previously [28, 31]. Univariate analysis was performed by a selection of specific vibrational bands of interest and an integration of the band intensity after local baseline subtraction. Multivariate analysis, involving both principal component analysis (PCA) and hierarchical cluster analysis (HCA) using Wards clustering method, was performed on Raman imaging data matrices to visualize regions in cells with high Raman spectral similarities [32, 33]. Data for PCA was preprocessed by auto-scaling to the mean of the spectra along the frequency axis. HCA makes use of the scores obtained from the PCA data and was preprocessed with a first derivative Savitsky-Golay algorithm (with seven-point smoothing and quadratic polynomial fit) to minimize small variations in the baseline, and subsequently auto-scaled to the mean of the spectra along the frequency axis. For quantitative comparison between Raman and fluorescence imaging, the Dice coefficient [34] was calculated as follows:

$$
\frac{2 h}{a+b}
$$

in which $\mathrm{h}$ is the overlap between the two (binary) images, and a and b represent the surface areas in the separate images. The Dice coefficient ranges from 0 to 1 , in which 0 indicates no overlap and 1 indicates perfect agreement. All data manipulations were performed in routines written in MATLAB 7.6 (The MathWorks). HCA and PCA were performed using PLS toolbox (Eigenvectors Research Inc.). 

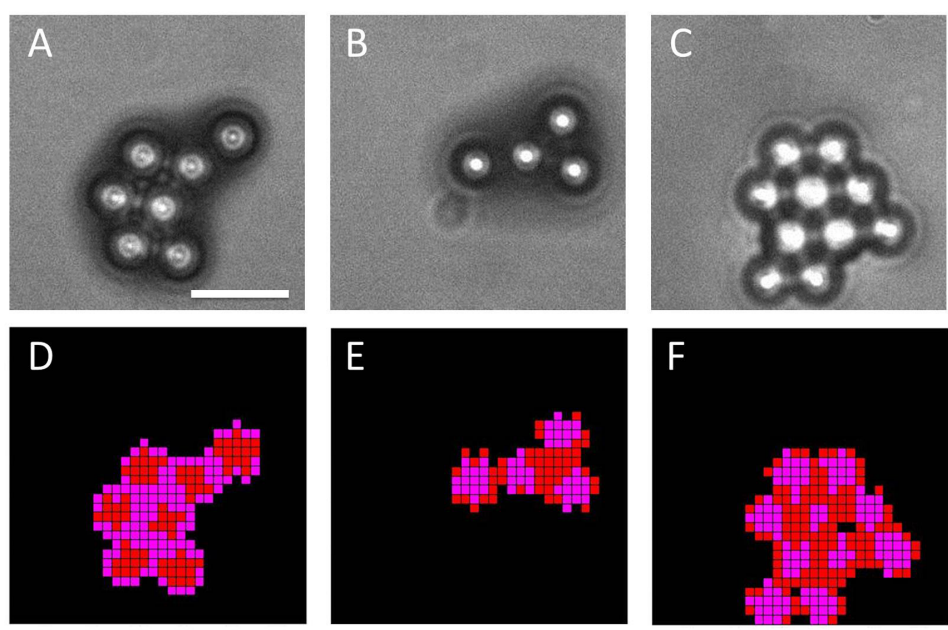

Combine individual scans:
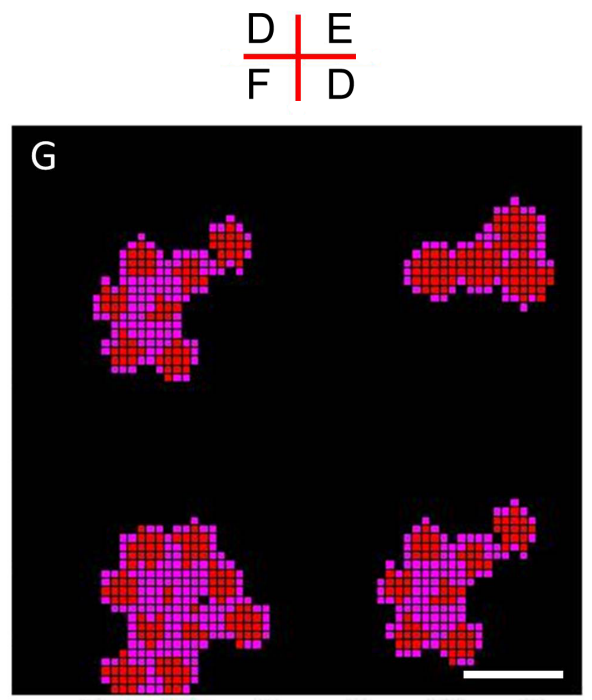

Figure 4.1: Validation of image-stitching method using MATLAB. (A-C) Brightfield microscopic images of multiple clusters of polystyrene microspheres (5 $\mu \mathrm{m}$ in diameter). (D-E) Corresponding Raman microspectroscopic images of the same microsphere clusters were acquired in 'Raman imaging mode' by scanning a 32x32 raster pattern over a sample area of $30 \times 30 \mu \mathrm{m}$, resulting in a data matrix consisting of 1024 spectra. (G) Datasets of D, E and $\mathrm{F}$ were combined to form a larger $(2 \times 2)$ data matrix consisting of 4096 spectra (covering a total sample area of $60 \times 60 \mu \mathrm{m}$ ). This combined dataset was then further processed to create one combined image. Scale bars represent $10 \mu \mathrm{m}$. 


\subsection{Results}

\subsubsection{Raman spectra of purified hormones}

Raman spectroscopy on purified hormones was performed to identify Raman markers for insulin and glucagon, the two main hormones within the islets of Langerhans produced by the beta-cells (50-70\%) and alpha-cells (20-35\% of islet cells), respectively $[35,36]$. Spectra a and b in Figure $4.2 \mathrm{~A}$ represent the Raman spectra of insulin and glucagon. Similarities in the spectra are mainly caused by vibrations in phenylalanine and tyrosine, amino acids that are part of the molecular structure of both insulin and glucagon. More interestingly, spectral differences between the two hormones were observed that could be explained by their molecular structure (Figure 4.2B). Insulin contains six cysteine groups that are linked with three disulfide (S-S) bridges. Molecular vibrations of these bridges result in specific Raman bands at 520 $\mathrm{cm}^{-1}$ (S-S vibration) and $662 \mathrm{~cm}^{-1}$ (C-S stretching) [37-39]. Tryptophan, one of the building blocks of glucagon, has molecular vibrations that result in Raman bands at 759 (aromatic ring breathing) and $1552 \mathrm{~cm}^{-1}(\mathrm{C}=\mathrm{C}$ vibration) [37]. Because tryptophan is not present in insulin and disulfide bridges are not present in glucagon, these Raman bands may be used to distinguish between insulin and glucagon. However, since both tryptophan and disulfide bridges between cysteines are also present in other polypeptides, these amino acids may only serve as indirect markers of glucagon and insulin.

Additionally, we measured a number of other hormones that are produced by islets of Langerhans, albeit in much lower amounts than insulin and glucagon. Amylin is co-secreted with insulin by beta-cells (molar ratio amylin to insulin is approximately 2:100) [40], somatostatin is produced by delta-cells ( $<10 \%$ of total islet cells), and pancreatic polypeptide is produced by PP-cells $(<5 \%$ of cells) [36]. Pancreatic polypeptide does not contain any tryptophan or cysteine groups, reflected by the absence of the corresponding Raman bands. The polypeptides amylin and somatostatin both contain one disulfide bridge, which in contrast to the three bridges in insulin, results in strongly reduced bands at 520 and $662 \mathrm{~cm}^{-1}$. Like glucagon, somatostatin contains one amino acid tryptophan and thus also shows Raman bands at 759 and $1552 \mathrm{~cm}^{-1}$ (Figure 4.2A).

\subsubsection{Raman fingerprint of alpha- and beta-cell lines}

Raman spectral mapping was performed on INS-1E rat insulinoma beta-cells, MIN6 mouse insulinoma beta-cells and $\alpha \mathrm{TC} 6$ rat alpha-cells. The averaged spectra $(\mathrm{n}=5)$ for each cell type are shown in Figure 4.3A. The spectra show several bands characteristic for cells and biological samples, which can be assigned to DNA $\left(788 \mathrm{~cm}^{-1}\right)$, phenylalanine $\left(1002 \mathrm{~cm}^{-1}\right)$, proteins $\left(1152 \mathrm{~cm}^{-1}\right)$, lipids and amides $\left(1245-1280 \mathrm{~cm}^{-1}\right)$, $\mathrm{CH} 2$ bending of proteins and lipids $\left(1447 \mathrm{~cm}^{-1}\right)$, and $\mathrm{C}=\mathrm{C}$ groups in unsaturated fatty acids $\left(1659 \mathrm{~cm}^{-1}\right)$. HCA on the averaged total cell spectra successfully classifies the spectra in three separate clusters. Although there is some variation within one cell type, the variance between the spectra of one cell type is much smaller than the 

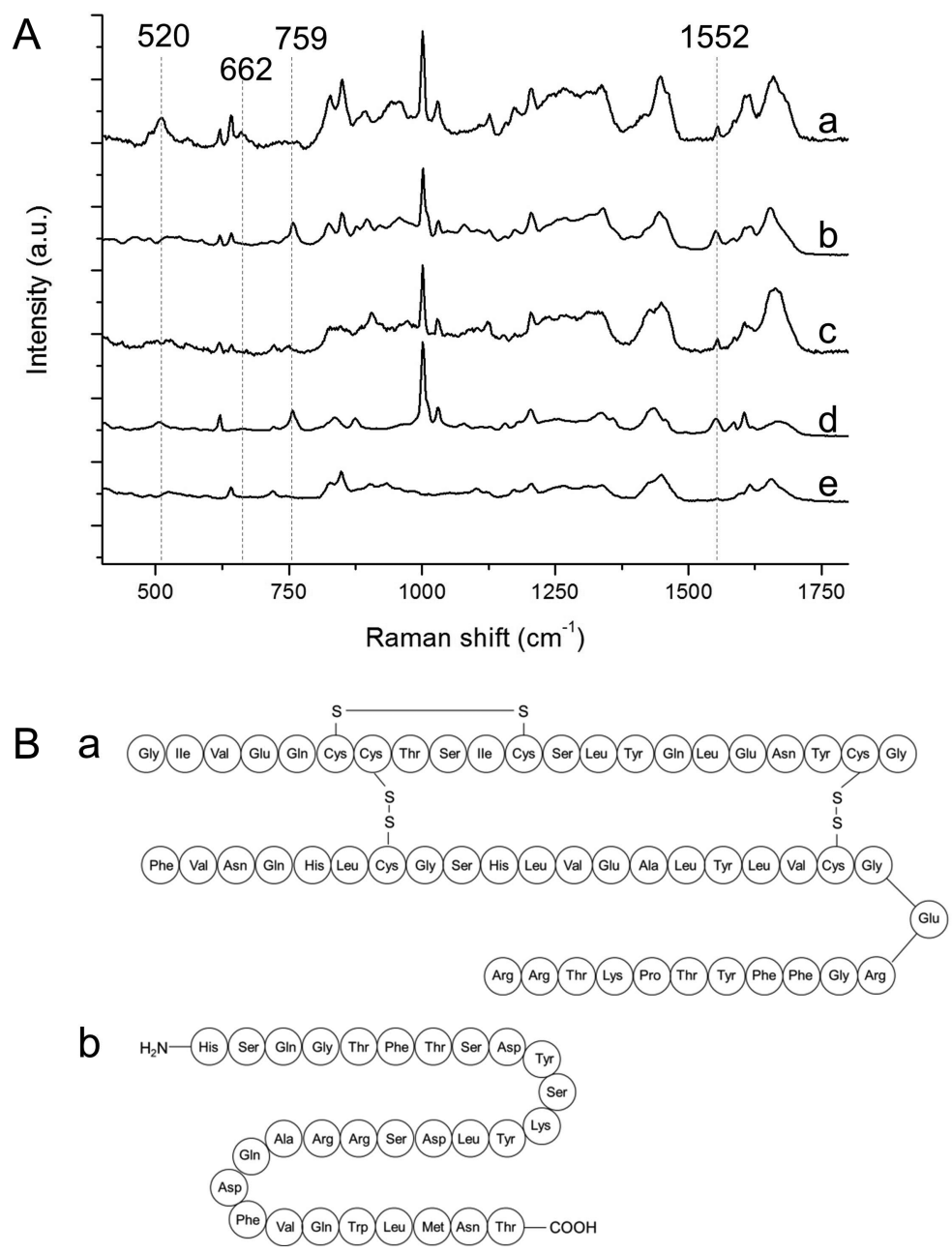

Figure 4.2: Confocal Raman spectroscopy of purified hormones. (A) Raman fingerprint of insulin (a), glucagon (b), amylin (c), somatostatin (d), pancreatic polypeptide (e). Spectra are vertically offset for clear representation. Bands specific for sulfide bridges between cysteines in insulin were found at 520 and $662 \mathrm{~cm}^{-1}$. Tryptophan-specific bands at 759 and $1552 \mathrm{~cm}^{-1}$ were found in spectrum of glucagon. (B) Amino acid composition of insulin (a), containing three Raman-active sulfide bridges between cysteine groups, and glucagon (b), containing the Raman-active amino acid tryptophan. 
variance between the spectra of the different cell types (Figure 4.3B).

In addition to the total cell spectra, we have investigated the molecular fingerprint of just the cytoplasm of the cell, where proteins are stored in the secretory vesicles. A three-level cluster analysis was performed to separate the spectra corresponding to the cytoplasm from the spectra corresponding to the nucleus or background. Principal component analysis (PCA) was performed for unsupervised analysis of the cytoplasm spectra. This method assigns scores to reveal subsequent levels of variation in the dataset, with the first principal component (PC) reflecting the highest amount of variation. Each spectrum in the dataset acquires a score with respect to each level of variation. Following the analysis it was observed that the third principal component (responsible for $1.4 \%$ of the variance) accounts for the separation of the alpha-cell line from the beta-cell lines. PC1 (91.5\%) and PC2 (6.1\%) did not contribute to distinguish the various cell types, and represent intercellular variation. Figure 4.3C shows the individual scores of PC3 for each Raman spectrum analyzed, in which two distinct groups were observed. The INS-1E and MIN6 beta-cells are characterized by negative PC3 scores, while the $\alpha$ TC6 alpha-cells show positive PC3 scores. To determine the biochemical features that are responsible for clustering of the two groups, the loadings on PC3 were analyzed (Figure 4.3D). The PC3 loadings spectrum shows bands at $1264,1298,1440$ and $1660 \mathrm{~cm}^{-1}$, which resemble lipid contributions of predominantly unsaturated fatty acids. In addition, the band at $716 \mathrm{~cm}^{-1}$ is characteristic for the phospholipid phosphatidylcholine. This indicates that differences in intracellular lipid concentration account for the classification of ( $\alpha$ TC6) alpha-cells and (MIN6 and INS-1E) beta-cells.

\subsubsection{Raman imaging of INS-1E beta-cells}

High-resolution Raman imaging is performed on individual INS-1E cells to identify intracellular insulin. INS-1E cell morphology was examined using bright field microscopy and the same cell was imaged using Raman microspectroscopic scanning (Figure 4.4A). Three-level hierarchical cluster analysis of the dataset was performed, resulting in the Raman cluster image (Figure 4.4B). This illustrates the spatial variation of the Raman signal by distinguishing the nucleus (red cluster) and cytoplasm of the cell (purple cluster) from the background (black cluster). Figure 4.4C shows the corresponding cluster spectra for nucleus and cytoplasm, corrected for the background spectrum. Univariate analysis on selected Raman bands was performed to visualize the presence and distribution of specific compounds. The intensity of the $788 \mathrm{~cm}^{-1}$ band for DNA was used to locate the cell nucleus (Figure 4.4D), which corresponds to the red cluster in Figure 4.4B. Raman mapping of the $520 \mathrm{~cm}^{-1}$ band shows high local concentrations of disulfide-bridged cysteine groups which could indicate the accumulation of insulin in the cytoplasm of the INS-1E cell at these locations (Figure 4.4E). 

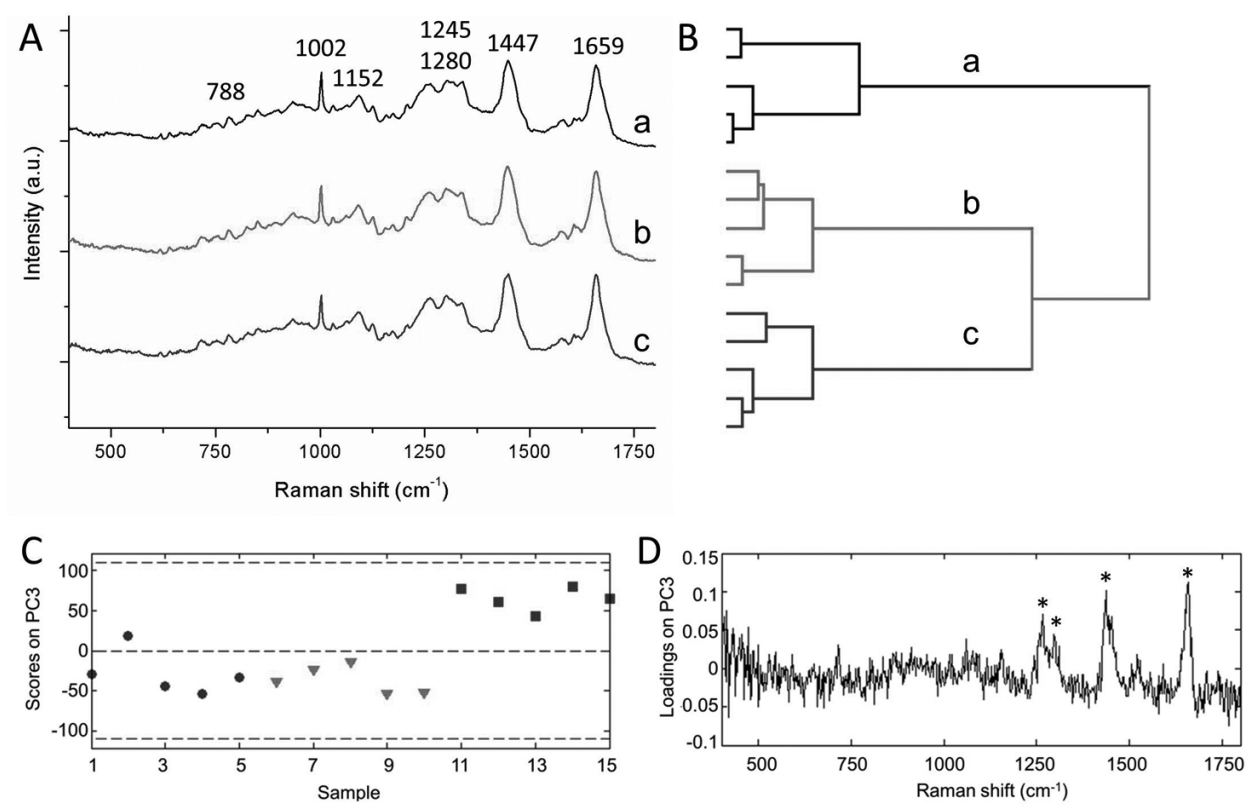

Figure 4.3: Raman spectroscopic evaluation of insulinoma cell lines. (A) Average Raman fingerprints of MIN6 (a), INS-1E (b) and $\alpha$ TC6 (c) cells were acquired by averaging the spectra of 5 randomly chosen individual cells. Spectra are vertically offset for clear representation. (B) Multivariate data analysis was applied to the dataset to objectively assess subtle differences in the fingerprint region of the spectra. Hierarchical cluster analysis (HCA) classifies the various cell types in separate clusters. (C) PC3 scores from PCA on spectra of the cell cytoplasm clearly distinguish the alpha from the beta cells. $\bullet=$ MIN6 cells, $\mathbf{\nabla}=$ INS-1E cells, $\mathbf{\square}=\alpha$ TC6 cells. (D) PC3 loadings indicate the Raman bands that are mainly involved in the separation of alpha and beta cells. Band positions characteristic for unsaturated fatty acids are marked with an asterisk. 

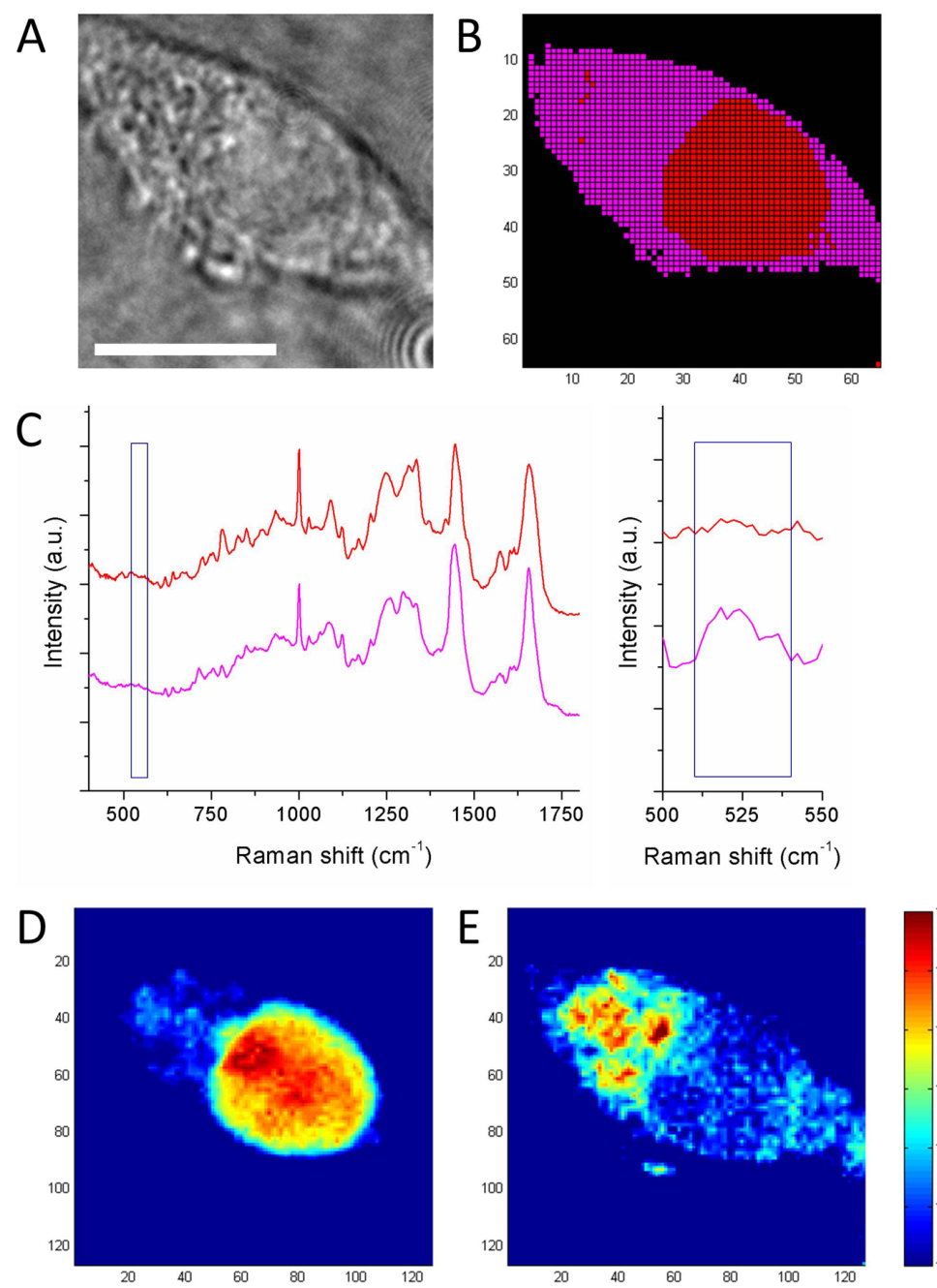

Figure 4.4: Label-free Raman imaging of rat insulinoma INS-1E beta-cells. (A) Brightfield image of an INS-1E cell. (B) Raman cluster image acquired by scanning the confocal laser beam in a $64 \times 64$ raster pattern. Analysis with 3 levels of clustering illustrates the spatial variation of Raman signal within a cell by distinguishing subcellular structures. (C) Corresponding Raman cluster spectra (corrected for background) show the average signal for cytoplasm (magenta) and nucleus (red). Enlargement shows the Raman band at 520 $\mathrm{cm}^{-1}$, specific for difsulfide-bridged cysteine. Spectra are vertically offset for clear representation. Integrating over specific Raman bands shows (D) the distribution of DNA $\left(783 \mathrm{~cm}^{-1}, \Delta=26 \mathrm{~cm}^{-1}\right)$ corresponding to red cluster in $\mathrm{B}$, and (E) the distribution of disulfide bridges between cysteine groups (524 $\left.\mathrm{cm}^{-1}, \Delta=30 \mathrm{~cm}^{-1}\right)$. Scale bar represents $10 \mu \mathrm{m}$. 


\subsubsection{Raman imaging of human pancreatic islets}

We have performed hyperspectral Raman imaging (with a step size of $1.88 \mu \mathrm{m}$ ) on human donor islets and compared their spectral characteristics to those of pure insulin and glucagon. A brightfield microscopy image of a representative human islet section is shown in Figure 4.5A. The islets were stained for insulin and glucagon to visualize the distribution of alpha- and beta-cells (Figure 4.5B). Three-level cluster analysis was performed on the entire fingerprint region to objectively assess the spatial variation of the Raman signal. The green and blue clusters, representing the islet, indicate some variation in the concentration of DNA, lipids and proteins throughout the tissue (Figure 4.5C and D). Univariate Raman spectral imaging was performed to investigate the distribution of specific compounds within the whole islet section. The intensity and distribution of the $788 \mathrm{~cm}^{-1}$ band visualizes the presence of DNA, and was used to identify the cell nuclei in islet cells. Moreover, the distribution of the Raman band at $520 \mathrm{~cm}^{-1}$ specific for disulfide bridges between cysteine groups, and the tryptophan band at $1552 \mathrm{~cm}^{-1}$ are depicted in Figure 4.5E-G. However, at low resolution these bands did not clearly correlate with the immunolabeling against insulin and glucagon.

\subsubsection{High resolution Raman imaging of human pancreatic islets}

Since proteins are stored in small secretory vesicles in the cell cytoplasm, we performed high-resolution hyperspectral Raman imaging with a step size of $0.94 \mu \mathrm{m}$ on part of the islet preparation (as indicated by a white square in Figure 4.5B). Figure 4.6A$\mathrm{C}$ visualizes the distribution of Raman bands specific for DNA, disulfide bridges in cysteine and tryptophan. At this higher (subcellular) resolution, a clear distribution of these molecules was observed which coincided with fluorescence labeling for cell nuclei, insulin and glucagon, respectively (Figure 4.6E-G). To compare the obtained Raman images with images obtained using conventional fluorescence microscopy, we generated overlay images with the Raman signal in purple and the fluorescence signal in green (Figure 4.6I-K). A quantitative comparison was made by calculating the Dice coefficient, which gives a value for overlap between the two images. For DNA, we obtained a Dice coefficient of 0.69 indicating a strong correlation between the Raman signal and the fluorescence signal, which is depicted in the corresponding overlay image. We also found a clear correlation for insulin and glucagon. However, this correlation is somewhat lower than for DNA resulting in Dice coefficients of 0.36 for insulin and 0.19 for glucagon. The merged Raman image shows the distribution of DNA, disulfide bridges in cysteine and tryptophan (Figure 4.6D), whereas Figure 4.6H represents the merged image obtained by conventional fluorescence immunolabeling.

\subsection{Discussion}

Our study has explored the feasibility of Raman spectroscopy to identify insulin and glucagon within human islets of Langerhans. We used Raman spectroscopy to characterize cell lines and human donor pancreatic islets at the sub-cellular level. By performing Raman measurements on purified hormones we showed that Raman bands 

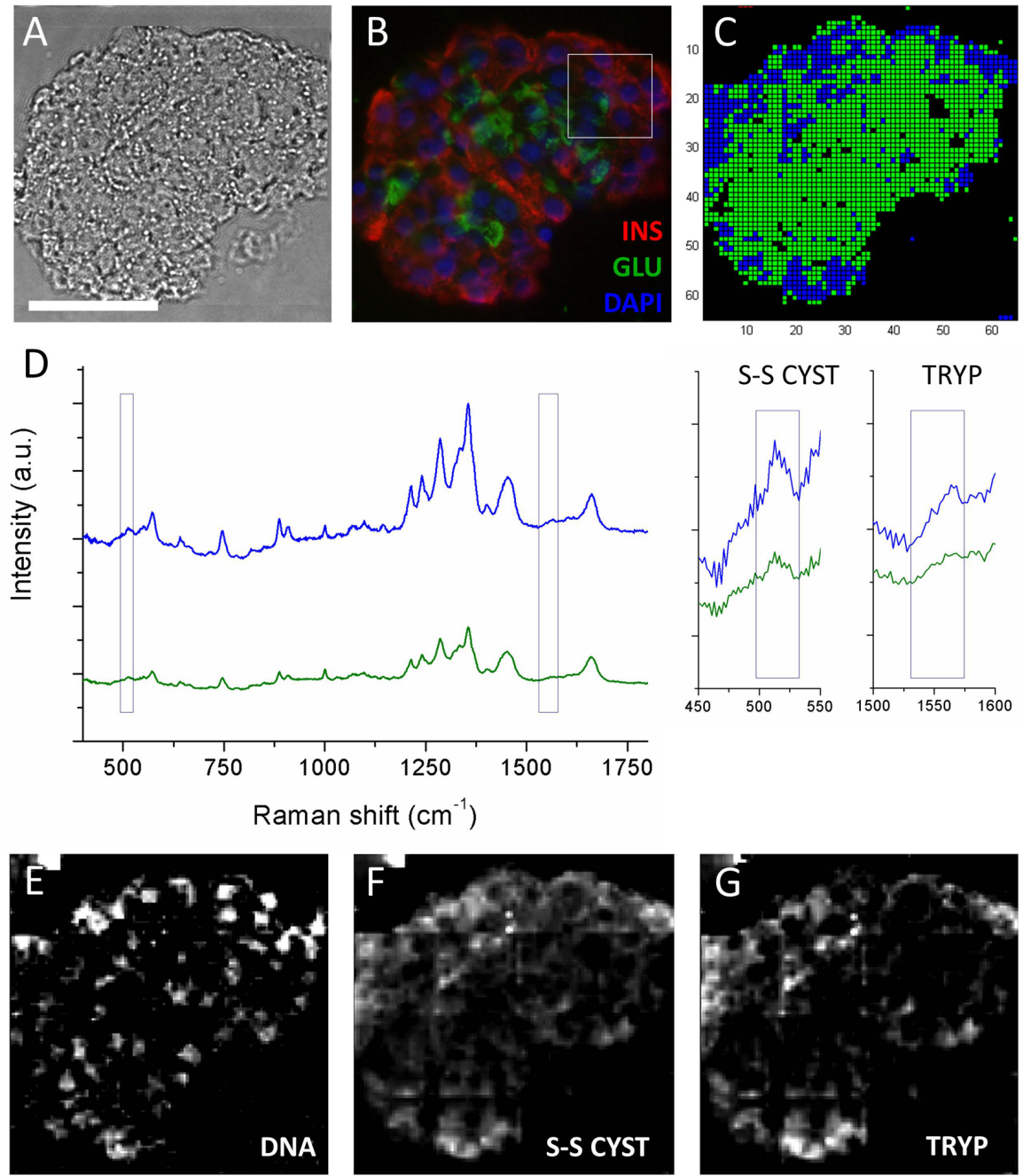

Figure 4.5: Label-free Raman imaging of primary human islets of Langerhans. (A) Brightfield microscopy image of a cryosection of an islet of Langerhans. (B) Fluorescence microscopy image of the islet stained for DNA (blue), insulin (red) and glucagon (green). (C) Corresponding Raman cluster image and (D) corresponding Raman cluster spectra, acquired by scanning the confocal laser bundle in a $64 \times 64$ raster pattern. Analysis with 3 levels of clustering illustrates the spatial variation of Raman signal within the islet. Enlargement shows the disulfide band at 520 and the tryptophan band at $1552 \mathrm{~cm}^{-1}$. Spectra are vertically offset for clear representation. The bottom panel shows hyperspectral Raman images for (E) DNA $\left(783 \mathrm{~cm}^{-1}, \Delta=26\right.$ $\left.\mathrm{cm}^{-1}\right)$, (F) disulfide bridges between cysteine groups $\left(524 \mathrm{~cm}^{-1}, \Delta=30 \mathrm{~cm}^{-1}\right)$ and $(\mathrm{G})$ tryptophan $\left(1545 \mathrm{~cm}^{-1}, \Delta=21 \mathrm{~cm}^{-1}\right)$. Minor artifacts caused by the image-stitching procedure are visible in the Raman images. Scale bar represents $50 \mu \mathrm{m}$. 

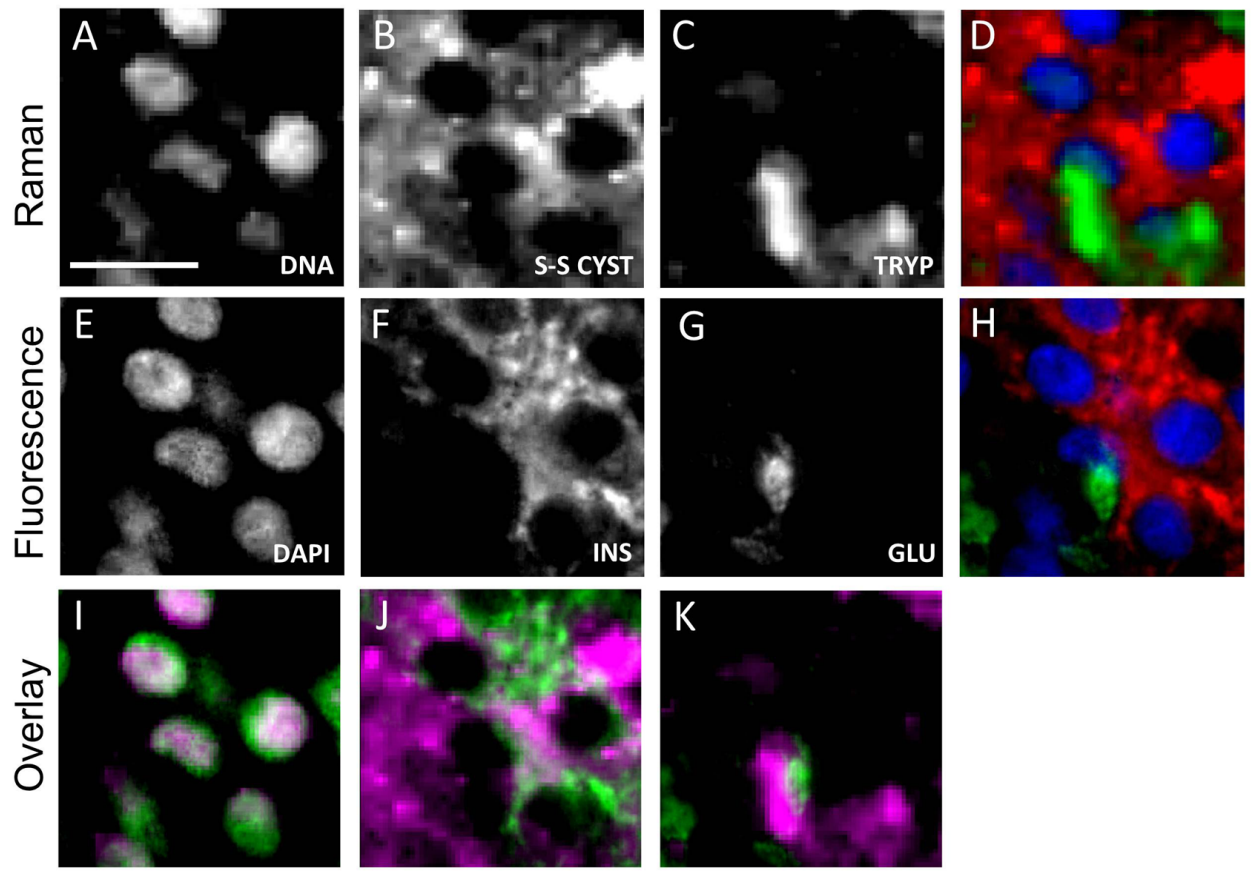

Figure 4.6: Label-free detection of insulin and glucagon in human islets. The top panel shows the univariate Raman images of a cryosection of an islet of Langerhans for (A) DNA $\left(783 \mathrm{~cm}^{-1}, \Delta=26 \mathrm{~cm}^{-1}\right)$, (B) disulfide bridges between cysteine groups $\left(524 \mathrm{~cm}^{-1}, \Delta=30 \mathrm{~cm}^{-1}\right)$ and (C) tryptophan $\left(1545 \mathrm{~cm}^{-1}, \Delta=21 \mathrm{~cm}^{-1}\right)$. The second panel shows the corresponding fluorescence microscopy images stained for (E) DNA, (F) insulin and (G) glucagon. The bottom panel shows the overlay images of the Raman image (in purple) and fluorescence image (green) for (I) DNA, (J) insulin and (K) glucagon. (D) Merged Raman spectroscopy image images of DNA (blue), difsulfide bridged cysteine (red) and tryptophan (green). (H) Merged fluorescence image of DAPI (blue), insulin (red) and glucagon (green). Scale bar represents $50 \mu \mathrm{m}$. 
specific for disulfide bridges between cysteine groups in insulin and tryptophan in glucagon are mutually exclusive, and could therefore be used for the label-free distinction between both hormones. High-resolution univariate Raman imaging for the $520 \mathrm{~cm}^{-1}$ band on individual beta-cells showed the distribution of disulfide bridges in the cytoplasm of the cells. These findings correlate with the knowledge that insulin is accumulated in large dense-core vesicles within the cytoplasm of pancreatic beta-cells and therefore locally contain high concentrations of cysteine [41, 42], suggesting that Raman spectroscopy allows for the label-free detection of intracellular insulin.

Subsequently, we investigated whether we could use the Raman markers specific for disulfide bridges and tryptophan to distinguish between insulin-producing betacells and glucagon-producing alpha-cells within human islets of Langerhans. Hyperspectral imaging on human islet preparations with a step size of $1.88 \mu \mathrm{m}$ enabled identification of individual cells but did not provide detailed subcellular information. Since hormones such as insulin and glucagon are stored in vesicles with an estimated diameter of $0.3 \mu \mathrm{m}$ [43], high-resolution hyperspectral Raman imaging was performed on smaller areas of the islet preparation in which we decreased the step size from 1.88 to $0.94 \mu \mathrm{m}$, resulting in more detailed information. In this case every pixel represents $0.88 \mu \mathrm{m}^{2}$ of the sample, providing molecular information on a sub-micrometer level. Univariate analysis of selected Raman bands was performed to display the distribution of DNA, disulfide-bridged cysteines and tryptophan which corresponded with the corresponding fluorescence microscopy images for DNA, insulin and glucagon as demonstrated by overlaying the images obtained by both techniques. We quantitatively compared the correlation between label-free Raman imaging and conventional fluorescence microscopy by calculating the Dice coefficients (DC). The highest Dice coefficient was found for DNA ( $\mathrm{DC}=0.69)$, while significantly lower coefficients for insulin ( $\mathrm{DC}=0.36)$ and glucagon $(\mathrm{DC}=0.19)$ were determined. Several factors can be attributed to the fact that the images of both techniques do not perfectly match.

First, because tryptophan and disulfide bridges between cysteines are also present in other polypeptides, these amino acids only serve as indirect markers of glucagon and insulin. However, since both hormones are stored at high concentrations in secretory granules of alpha- and beta-cells, this should locally result in strong Raman bands at the described wavenumbers. Since insulin contains six disulfide-bridged cysteine groups, whereas glucagon only contains one tryptophan molecule, we can assume that tryptophan as a marker for glucagon is less specific than disulfide bridges are for insulin. In addition, somatostatin produced by delta cells also contains one tryptophan molecule. Delta cells which commonly comprise $11 \%$ of the islet cell population, whereas $35 \%$ is composed of alpha-cells [35], will therefore contribute to the tryptophan-specific Raman signal.

Second, there is a considerable difference regarding the spatial resolution of both imaging methods used. Raman spectroscopic imaging is performed by stepwise moving the laser beam over the sample in a raster pattern, while simultaneously taking a single Raman spectrum at each stop, creating an array of pixels. Subsequently, band integrations are performed on bands of interest and with these data an image is reconstructed. The spatial resolution of the Raman image is thus determined by the step size of the laser focal spot. For detailed Raman imaging on islets, we used 
a step size of $0.94 \mu \mathrm{m}$. In comparison, the resolution of fluorescence microscopy is limited by the diffraction of light to a few hundred nanometers. Last, the same islet section was first imaged using Raman spectroscopy and subsequently immunolabeled for fluorescence microscopy, for which two separate microscope systems were used.

Our findings show that high-resolution hyperspectral Raman imaging with a step size smaller than $1 \mu \mathrm{m}$, enables the label-free distinction of insulin and glucagon within human islets of Langerhans. However, it does not yet provide information on the viability of the tissue or determines the islets ability to respond to a glucose stimulus. On the other hand, Notingher and colleagues have already reported the use of Raman spectroscopy to distinguish viable from dead cells [43]. Their findings suggest the possibility of using Raman spectroscopy to quantify viability of pancreatic islet grafts. Further studies need to be performed to investigate the feasibility of performing real-time studies on viability and functioning of islet preparations using confocal Raman spectroscopy. In such analysis, it will also be beneficial to correlate the islet parameters to the final patient outcome after transplantation. This would help selecting optimal tissue for transplantation $[45,46]$.

\subsection{Conclusion}

We demonstrate, in contrast to conventional histological methods, that Raman spectroscopy enables the label-free classification of various cell types in human islets and pancreatic cell lines. Measurements on purified hormones revealed Raman markers specific for disulfide bridges between cysteine groups $\left(520 \mathrm{~cm}^{-1}\right)$ and tryptophan $(1552$ $\mathrm{cm}^{-1}$ ) that can be used to distinguish between insulin and glucagon. High-resolution Raman imaging, using sub-micrometer steps, for these specific bands enables local detection of high concentrations of insulin and glucagon in human pancreatic islet cells. This method provides information on composition and structural organization of pancreatic endocrine tissue in a label-free manner, and may help to accurately monitor islet quality before transplantation in patients suffering from type 1 diabetes in the future. 


\section{References}

1. Zimmet, P., K.G. Alberti, and J. Shaw, Global and societal implications of the diabetes epidemic. Nature, 2001. 414(6865): p. 782-7.

2. Karvonen, M., et al., Incidence of childhood type 1 diabetes worldwide. Diabetes Mondiale (DiaMond) Project Group. Diabetes Care, 2000. 23(10): p. 1516-26.

3. Patterson, C.C., et al., Incidence trends for childhood type 1 diabetes in Europe during 1989-2003 and predicted new cases 2005-20: a multicentre prospective registration study. Lancet, 2009. 373(9680): p. 2027-33.

4. Soltesz, G., C.C. Patterson, and G. Dahlquist, Worldwide childhood type 1 diabetes incidence-what can we learn from epidemiology? Pediatr Diabetes, 2007. 8 Suppl 6: p. 6-14.

5. Nathan, D.M., Long-term complications of diabetes mellitus. N Engl J Med, 1993. 328(23): p. 1676-85.

6. Bruno, G. and A. Landi, Epidemiology and costs of diabetes. Transplant Proc, 2011. 43(1): p. 327-9.

7. Shapiro, A.M. and J.R. Lakey, Future trends in islet cell transplantation. Diabetes Technol Ther, 2000. 2(3): p. 449-52.

8. Langer, R.M., Islet transplantation: lessons learned since the Edmonton breakthrough. Transplant Proc, 2010. 42(5): p. 1421-4.

9. Ryan, E.A., et al., Five-year follow-up after clinical islet transplantation. Diabetes, 2005. 54(7): p. 2060-9.

10. Ricordi, C., Quantitative and qualitative standards for islet isolation assessment in humans and large mammals. Pancreas, 1991. 6(2): p. 242-4.

11. Yamamoto, T., et al., Quality control for clinical islet transplantation: organ procurement and preservation, the islet processing facility, isolation, and potency tests. J Hepatobiliary Pancreat Surg, 2009. 16(2): p. 131-6.

12. Antkowiak, P.F., et al., Noninvasive assessment of pancreatic beta-cell function in vivo with manganese-enhanced magnetic resonance imaging. American Journal of Physiology-Endocrinology and Metabolism, 2009. 296(3): p. E573-E578.

13. Virostko, J., et al., Bioluminescence Imaging in Mouse Models Quantifies beta Cell Mass in the Pancreas and After Islet Transplantation. Molecular Imaging and Biology, 2010. 12(1): p. 42-53.

14. Moore, A., S. Bonner-Weir, and R. Weissleder, Noninvasive in vivo measurement of beta-cell mass in mouse model of diabetes. Diabetes, 2001. 50(10): p. 2231-6.

15. Raman, C.V. and K.S. Krishnan, A new type of secondary radiation (Reprinted from Nature, vol 121, pg 501-502, 1928). Current Science, 1998. 74(4): p. 381-381.

16. Mariani, M.M., P.J. Day, and V. Deckert, Applications of modern micro-Raman spectroscopy for cell analyses. Integr Biol (Camb), 2010. 2(2-3): p. 94-101.

17. Notingher, I. and L.L. Hench, Raman microspectroscopy: a noninvasive tool for studies of individual living cells in vitro. Expert Rev Med Devices, 2006. 3(2): p. 215-34.

18. Swain, R.J. and M.M. Stevens, Raman microspectroscopy for non-invasive biochemical analysis of single cells. Biochem Soc Trans, 2007. 35(Pt 3): p. 544-9.

19. Chan, J.W. and D.K. Lieu, Label-free biochemical characterization of stem cells 
using vibrational spectroscopy. J Biophotonics, 2009. 2(11): p. 656-68.

20. Chan, J.W., et al., Label-free separation of human embryonic stem cells and their cardiac derivatives using Raman spectroscopy. Anal Chem, 2009. 81(4): p. 1324-31. 21. Rong, X., et al., Real time detection of single living pancreatic beta-cell by laser tweezers raman spectroscopy: High glucose stimulation. Biopolymers, 2010.

22. Ellis, D.I., et al., Illuminating disease and enlightening biomedicine: Raman spectroscopy as a diagnostic tool. Analyst, 2013. 138(14): p. 3871-84.

23. Ellis, D.I. and R. Goodacre, Metabolic fingerprinting in disease diagnosis: biomedical applications of infrared and Raman spectroscopy. Analyst, 2006. 131(8): p.

875-85. 24. Petrich, W., et al., Disease pattern recognition in infrared spectra of human sera with diabetes mellitus as an example. Appl Opt, 2000. 39(19): p. 3372-9.

25. Lilla, V., et al., Differential gene expression in well-regulated and dysregulated pancreatic beta-cell (MIN6) sublines. Endocrinology, 2003. 144(4): p. 1368-79.

26. Merglen, A., et al., Glucose sensitivity and metabolism-secretion coupling studied during two-year continuous culture in INS-1E insulinoma cells. Endocrinology, 2004. 145(2): p. 667-78. 27. van Manen, H.J., A. Lenferink, and C. Otto, Noninvasive imaging of protein metabolic labeling in single human cells using stable isotopes and Raman microscopy. Anal Chem, 2008. 80(24): p. 9576-82.

28. Uzunbajakava, N., et al., Nonresonant confocal Raman imaging of DNA and protein distribution in apoptotic cells. Biophys J, 2003. 84(6): p. 3968-81.

29. Pully, V.V. and C. Otto, The intensity of the $1602 \mathrm{~cm}(-1)$ band in human cells is related to mitochondrial activity. Journal of Raman Spectroscopy, 2009. 40(5): p. 473-475.

30. Jue, T., Biomedical applications of biophysics. Handbook of modern biophysics. 2010, New York: Humana Press. x, 237 p.

31. van Manen, H.J., et al., Single-cell Raman and fluorescence microscopy reveal the association of lipid bodies with phagosomes in leukocytes. Proc Natl Acad Sci U S A, 2005. 102(29): p. 10159-64.

32. Hervada-Sala, C. and E. Jarauta-Bragulat, A program to perform Ward's clustering method on several regionalized variables. Computers \& Geosciences, 2004. 30(8): p. $881-886$.

33. Ward, J.H., Hierarchical Grouping to Optimize an Objective Function. Journal of the American Statistical Association, 1963. 58(301): p. 236-\&.

34. Dice, L.R., Measures of the Amount of Ecologic Association between Species. Ecology, 1945. 26(3): p. 297-302.

35. Brissova, M., et al., Assessment of human pancreatic islet architecture and composition by laser scanning confocal microscopy. J Histochem Cytochem, 2005. 53(9): p. 1087-97.

36. Cabrera, O., et al., The unique cytoarchitecture of human pancreatic islets has implications for islet cell function. Proc Natl Acad Sci U S A, 2006. 103(7): p. 23349 .

37. Movasaghi, Z., S. Rehman, and I.U. Rehman, Raman spectroscopy of biological tissues. Applied Spectroscopy Reviews, 2007. 42(5): p. 493-541.

38. Ortiz, C., et al., Identification of insulin variants using Raman spectroscopy. Anal Biochem, 2004. 332(2): p. 245-52. 
39. Yu, N.T., C.S. Liu, and D.C. O'Shea, Laser Raman spectroscopy and the conformation of insulin and proinsulin. J Mol Biol, 1972. 70(1): p. 117-32.

40. Alam, T., et al., Coordinate regulation of amylin and insulin expression in response to hypoglycemia and fasting. Diabetes, 1992. 41(4): p. 508-14.

41. Tsuboi, T., et al., Mammalian exocyst complex is required for the docking step of insulin vesicle exocytosis. Journal of Biological Chemistry, 2005. 280(27): p. 2556525570 .

42. Rutter, G.A. and E.V. Hill, Insulin vesicle release: walk, kiss, pause ... then run. Physiology (Bethesda), 2006. 21: p. 189-96.

43. Rorsman, P. and E. Renstrom, Insulin granule dynamics in pancreatic beta cells. Diabetologia, 2003. 46(8): p. 1029-45.

44. Notingher, I., et al., Spectroscopic study of human lung epithelial cells (A549) in culture: living cells versus dead cells. Biopolymers, 2003. 72(4): p. 230-40.

45. Bertuzzi, F. and C. Ricordi, Prediction of clinical outcome in islet allotransplantation. Diabetes Care, 2007. 30(2): p. 410-7.

46. Street, C.N., et al., Islet graft assessment in the Edmonton Protocol: implications for predicting long-term clinical outcome. Diabetes, 2004. 53(12): p. 3107-14. 


\section{Chapter 5}

\section{Controlled aggregation of primary human pancreatic islet cells using agarose microwell chips}

Janneke Hilderink, Siebe Spijker, Francoise Carlotti, Lydia Lange, Marten Engelse, Clemens van Blitterswijk, Eelco de Koning, Marcel Karperien, Aart van Apeldoorn 


\begin{abstract}
Islet transplantation is a promising treatment for patients with type 1 diabetes. As islets vary considerably in size, this is likely to affect efficacy after transplantation. The optimal islet size is not known. To reduce diffusion barriers and improve survival of isolated islets, generation of islets with optimal dimensions by dispersion and subsequent reassembly of islet cells may be beneficial. This study describes a microwell platform that supports the controlled and reproducible production of threedimensional cell clusters of human islet cells, while providing the cell-cell contact that is required for these cells to survive and function. We observed that human islet cell aggregates with a diameter of 100-150 $\mu \mathrm{m}$ (consisting of about 1000 cells) best resembled the physiological conditions of intact pancreatic islets as they showed the highest levels of PDX1, MAFA and INSULIN expression. High-throughput engineering of homogenous human islet cell aggregates using our microwell platform facilitates a variety of research applications, such as in vitro compound screening.
\end{abstract}




\subsection{Introduction}

Although allogeneic islet transplantation offers a promising therapy for patients with type 1 diabetes, this method is inefficient due to considerable islet loss shortly after transplantation [1, 2]. In addition to their use for clinical islet transplantation, isolated islets provide a valuable tissue source for diabetes research. Upon isolation, the main islet vasculature is damaged or destroyed. Therefore mass transport of relevant nutrients mainly depends on passive diffusion, which adversely affects the viability of isolated human islets [3]. It has been shown that small pancreatic islets $(\leq 150 \mu \mathrm{m})$, of both human and rodent origin are superior to larger islets in terms of survival and insulin secretion since they are less susceptible to central necrosis [4-6]. Generation of islets with optimal dimensions by islet dispersion and subsequent reassembly of single islet cells may have beneficial effects on islet survival after isolation.

Several authors have demonstrated that beta-cells require cell-cell contact to survive and function textitin vitro. The viability of MIN6 cells has been shown to improve when cells were cultured in close contact with each other [7]. Moreover, insulin secretion from these cells was increased in three-dimensional cell aggregates compared to two-dimensional monolayer cultures [8]. This improved secretory responsiveness was lost when cell-clusters were dispersed, and regained upon subsequent aggregation [911]. Similar results were obtained using primary islet cells of both rodent and human origin, stressing the importance of cell-cell interactions and three-dimensional culture [12-14].

Cell aggregates are commonly formed by static suspension cultures on ultra-low attachment tissue culture plastic, resulting in a heterogeneous aggregate population with a large variety in aggregate dimensions and number of cells per aggregate. Other conventional methods for cell aggregation include the hanging drop method which is widely used for embryoid body formation, and has also been used for the generation of pseudoislets from dispersed pancreatic rat islets [15-17]. Although this technique generates uniformly sized aggregates, this method is labor-intensive and therefore upscaling is limited. Better methods for controlled cell aggregation are being developed by several groups. Mendelsohn et al. showed the use of microcontact printing to form multilayered beta-cell clusters on laminin-patterned surfaces [18, 19]. Although aggregate size can be controlled, the cell clusters produced using this method are only a few cell layers thick and cannot be removed from the substrate for further research or implantation. Additionally, several microwell platforms have been developed and applied for controlled aggregation of various cell types such as embryonic stem cells [20-22], fibroblasts [22] and chondrocytes [23] in a high-throughput manner. Recent studies have demonstrated the use of microwells for the controlled aggregation of MIN6 mouse beta-cells, pancreatic progenitor cells, and dispersed rat islets of Langerhans [24-26]. However until now, controlled aggregation of dispersed human islet cells to create islets with optimal dimensions has not yet been reported using such systems.

Our study describes a high-throughput microwell platform optimized for the generation of stable and uniformly sized aggregates of human islet cells, which serves two main purposes. First, the platform supports the formation of three-dimensional 
clusters of beta-cells, providing the cell-cell contact that is required for these cells to survive and function. Second, since aggregate dimensions are highly controllable in this platform, it provides a tool to engineer islets with optimal dimensions. Tailoring aggregate dimensions could help to reduce islet cell death and increase the reproducibility of experimental results. We hypothesize that there is an optimal size and cell number for reassembly of human islet cells, and therefore we created primary human islet cell aggregates of various pre-defined dimensions by islet dispersion and subsequent reassembly of single islet cells and evaluated viability and functionality of the newly formed aggregates.

\subsection{Materials and methods}

\subsubsection{Insulinoma cell culture}

MIN6-B1 mouse insulinoma cells (kindly provided by Dr. P. Halban, University Medical Center, Geneva, Switzerland) [27] were cultured in high-glucose DMEM with 2.5 mM L-glutamine (Invitrogen) supplemented with 10\% FBS, $100 \mathrm{U} / \mathrm{ml}$ streptomycin, $100 \mu \mathrm{g} / \mathrm{ml}$ penicillin and $70 \mu \mathrm{M}$ freshly added $\beta$-mercaptoethanol. INS-1E rat insulinoma cells (kindly provided by Dr. B. Guigas, LUMC, Leiden, The Netherlands and Dr. P. Maechler, University Medical Center, Geneva, Switzerland) [28] were cultured in RPMI with $2.05 \mathrm{mM}$ L-glutamine (Invitrogen) supplemented with 5\% FBS, 100 $\mathrm{U} / \mathrm{ml}$ streptomycin, $100 \mu \mathrm{g} / \mathrm{ml}$ penicillin, $10 \mathrm{mM}$ HEPES, $1 \mathrm{mM}$ sodium pyruvate, $50 \mu \mathrm{M}$ freshly added $\beta$-mercaptoethanol. Cell cultures were maintained at $37^{\circ} \mathrm{C}$ in humidified air containing $5 \% \mathrm{CO}_{2}$. Medium was refreshed every 3 to 4 days and cells were replated when $80 \%$ confluency was reached.

\subsubsection{Primary human islet culture}

Human islets of Langerhans that could not be used for clinical islet transplantation were provided by the Leiden University Medical Center, Leiden, The Netherlands. Organs donors $(4 \mathrm{M} / 6 \mathrm{~F})$ had an average age of 5013 years and BMI of $233 \mathrm{~kg} . \mathrm{m} 2$. Islets were dispersed into single cells by adding $0.025 \%$ trypsin solution containing $10 \mu \mathrm{g} / \mathrm{ml}$ DNase (Pulmozyme, Genentech) and seeded onto agarose microwells for controlled cell aggregation. Intact islets and human islet cell aggregates were cultured in CMRL 1066 medium (5.5 mM glucose) (Mediatech) supplemented with 10\% FCS, $20 \mu \mathrm{g} / \mathrm{ml}$ ciprofloxacin, $50 \mu \mathrm{g} / \mathrm{ml}$ gentamycin, $2 \mathrm{mM}$ L-glutamin, $0.25 \mu \mathrm{g} / \mathrm{ml}$ fungizone, $10 \mathrm{mM}$ HEPES and $1.2 \mathrm{mg} / \mathrm{ml}$ nicotinamide. Cell cultures were maintained at $37^{\circ} \mathrm{C}$ in a $5 \%$ $\mathrm{CO}_{2}$ humidified atmosphere. Medium was refreshed every 3 to 4 days.

\subsubsection{Agarose microwell fabrication and cell aggregate formation}

Non-adherent agarose microwells were aseptically fabricated as described previously [29]. Briefly, microwell chips containing 2865 microwells with a diameter of $200 \mu \mathrm{m}$ and chips containing 1585 microwells with a diameter of $400 \mu \mathrm{m}$ were fabricated by pouring a $3 \%(\mathrm{w} / \mathrm{v})$ Ultrapure $^{\mathrm{TM}}$ agarose (Invitrogen) solution on negative molds of 
polydimethylsiloxane (PDMS). After agarose solidification, the molds were removed, covered with PBS and stored at $4{ }^{\circ} \mathrm{C}$ until usage. Before cell seeding, the agarose chips were pre-incubated in culture medium overnight at $37^{\circ} \mathrm{C}$. For cell aggregate formation, single cells were resuspended in fresh medium and seeded onto agarose chips at various densities resulting in aggregates consisting of 10, 25, 50, 100, 250, 500 and 1000 cells. Immediately after seeding, agarose chips were briefly centrifuged at $300 \mathrm{G}$ to allow the cells to settle down in the microwells. As a control, $1 \times 10^{5}$ cells were seeded onto ultra-low attachment plastic to allow spontaneous cell aggregation. Medium was refreshed every 1-2 days. Cell aggregates were cultured up to 7 days after which they were removed from the chips by upside down centrifugation (1 min at $300 \mathrm{G}$ ) or by medium flush, and used for further analysis. To measure the average aggregate diameter, microscopic images were taken and aggregate diameter was quantified using Image (NIH image). For INS-1E cell aggregates, at least 50 aggregates were measured. For human islet cell aggregates, at least 40 aggregates derived from islet preparations of 3 different human donors were measured.

\subsubsection{Scanning Electron Microscopy}

INS-1E cell aggregates were flushed out of the microwells, fixed in $4 \%$ (w/v) paraformaldehyde and embedded by mixing in $2 \%(\mathrm{w} / \mathrm{v})$ agarose. Samples were prepared for scanning electron microscopy by dehydration in increasing concentrations of ethanol (1 hour each step) and dried using critical point dryer equipment (CPD 030, BAL-TEC). The samples were sputter-coated with gold and imaged using a scanning electron microscope (XL30 ESEM-FEG, Philips).

\subsubsection{Cell viability}

Cell viability was assessed on day 7 by staining the cells with $6 \mu \mathrm{M}$ ethidium homodimer and $1 \mu \mathrm{M}$ calcein using a LIVE/DEAD Viability/Toxicity Kit (Invitrogen) and visualized using fluorescence microscopy (Nikon Eclipse E600). Viable cells were stained green, and DNA of dead cells was stained red. Staining was quantified as percentage of viable cells per total cell number, counting at least 100 cells per condition.

\subsubsection{Histological analysis}

Human islets, human islet cell aggregates and INS-1E cell aggregates were fixed in $4 \%$ $(\mathrm{w} / \mathrm{v})$ paraformaldehyde, washed in PBS, dehydrated in ethanol series, embedded in paraffin, and sectioned at 4-5 $\mu \mathrm{m}$ using a microtome (Microm HM355S, Thermo Scientific). Sections were deparaffinized in xylene, rehydrated in decreasing concentrations of ethanol (100-96-90-80-70\%) and rinsed in $\mathrm{H}_{2} \mathrm{O}$ and PBS. For immunohistochemical labeling of insulin, blocking was done using dual endogenous enzyme block (DAKO, Denmark). Sections were incubated with rabbit anti-human insulin polyclonal antibody (1:400, Santa-Cruz) for 1 hour at $21^{\circ} \mathrm{C}$, followed by subsequent washing steps in PBS and $1 \%(\mathrm{v} / \mathrm{v})$ BSA/PBS and incubated with HRP-goat anti-rabbit IgG secondary antibody $\left(1: 100\right.$, DAKO) for 1 hour at $21^{\circ} \mathrm{C}$. Sections were then rinsed in 
PBS and incubated for 4 minutes with DAB liquid chromogen system (DAKO), which yields a brown color. Counterstaining was performed using hematoxylin (Gills hematoxylin no. 3, Sigma-Aldrich) according to the manufacturers protocol and samples were visualized using a Nikon Eclipse E600 microscope. For fluorescent immunolabeling of insulin and glucagon, blocking was done with $0.1 \%(\mathrm{w} / \mathrm{v})$ normal donkey serum/PBS for 1 hour and antibodies were diluted in 1\% (v/v) lamb serum/PBS. Primary antibodies used were: 1:100 rabbit-anti-glucagon (Vector Labs) overnight at $4{ }^{\circ} \mathrm{C}$, and 1:200 guinea pig-anti-insulin (ABCAM) for 1.5 hours at $21^{\circ} \mathrm{C}$. Secondary antibodies used were: 1:200 biotin donkey anti-rabbit (Jackson ImmunoResearch), 1:200 streptavidin-Alexa488 (Invitrogen), 1:400 rhodamine donkey anti-guinea pig (Jackson ImmunoResearch), all incubated for 1 hour at $21^{\circ} \mathrm{C}$. Counterstaining was performed with $1 \mu \mathrm{g} / \mathrm{ml}$ 4'-6-diamidino-2-phenylindole (DAPI). Fluorescence was visualized using a Nikon Eclipse E600 microscope.

\subsubsection{Glucose stimulated insulin secretion test (GSIST)}

To test insulin secretory capacity, 3 groups of 50 human islets, human islet cell aggregates or INS-1E cell aggregates were hand-picked and transferred to an ultra-low attachment plate and incubated in a modified Krebs-Ringer bicarbonate buffer. INS$1 \mathrm{E}$ cell aggregates were pre-incubated for 2 hours in glucose-free culture medium, followed by a 30 minutes pre-incubation in glucose free incubation buffer. Subsequently, the INS-1E cell aggregates were incubated during 3 consecutive steps of 30 minutes in low glucose buffer $(2 \mathrm{mM})$, high-glucose buffer $(20 \mathrm{mM})$ and low glucose buffer $(2 \mathrm{mM})$ at $37^{\circ} \mathrm{C}$. Human islets and human islet cell aggregates were pre-incubated for 1.5 hours in glucose-free buffer followed by 3 successive incubation steps of 1 hour in low glucose buffer $(2 \mathrm{mM})$, high-glucose buffer $(20 \mathrm{mM})$ and low glucose buffer $(2 \mathrm{mM})$ at $37^{\circ} \mathrm{C}$. Medium samples were collected and concentrations of secreted insulin were determined by ELISA according to the manufacturers protocol (Mercodia, Sweden). Absorbance was analyzed with Thermo Scientific Multiscan Go $(450 \mathrm{~nm})$. After GSIS, aggregates were collected and analyzed for total DNA content using Quant-iT picogreen dsDNA assay kit (Invitrogen). Fluorescence was analyzed with a Perkin Elmer 1420 Multilabel counter (excitation 480 nm, emission $520 \mathrm{~nm}$ ). Secreted insulin was normalized to the total DNA amount. Stimulation index (SI) was calculated as a ratio of released insulin after high glucose stimulation divided by released after low glucose stimulation.

\subsubsection{Quantitative PCR}

Total RNA was extracted using RNeasy kit (Qiagen) according to the manufacturers protocol. Total RNA $(1 \mu \mathrm{g})$ was reverse transcribed using M-MLV reverse transcriptase (Invitrogen). Quantitative PCR (qPCR) was performed using a Light Cycler 480-II Real-time PCR system (Roche). Fold induction was calculated using deltaCT method with human $\beta$-actin as housekeeping gene. 


\subsubsection{Statistical analysis}

Statistical analyses were performed using one-way ANOVA and Bonferroni post-test. ${ }^{*} \mathrm{p} \leq 0.05,{ }^{* *} \mathrm{p} \leq 0.01,{ }^{* * *} \mathrm{p} \leq 0.001$.

\subsection{Results}

\subsubsection{Fabrication and validation of microwell platform}

Agarose microwell chips were fabricated using PDMS molds. The chips are compatible with standard 12-well cell culture plates and contain 2865 non-adherent microwells with a diameter of $200 \mu \mathrm{m}$ (Figure 5.1A). When a single cell suspension is seeded onto these chips, controlled aggregation is induced and stable cell clusters are formed, as schematically shown in Figure 5.1B. To visualize cell aggregation inside these microwells, we measured the aggregate diameter of INS-1E cell aggregates in time. Figure 5.1C shows that single INS-1E cells assembled as aggregates during the first two days after which the aggregates remained stable in size up to 7 days of culture. Additionally, scanning electron microscopy demonstrated that the INS-1E cell aggregates did not disintegrate after harvesting from the chip, indicative of their stable consistency, which was maintained during the next 7 days of suspension culture (Figure 5.1D). INS-1E cell aggregates obtained by conventional suspension culture on ultra-low attachment plates showed a large size distribution with an average aggregate diameter of $88 \mu \mathrm{m}(\mathrm{SD}=49)$, whereas controlled aggregation of 500 cells per well in our microwell platform resulted in uniformly sized aggregates of $93 \mu \mathrm{m}(\mathrm{SD}=16)$ (Figure $5.1 \mathrm{E})$.

\subsubsection{Controlled generation of insulinoma and primary human islet cell aggregates}

Controlled aggregation using these microwells was optimized using MIN6 and INS$1 \mathrm{E}$ insulinoma cell lines. These insulin-producing cell lines reflect primary beta-cell properties and are therefore widely used as a model for primary beta-cells [30, 31]. Cells were seeded onto microwell chips at various densities to generate aggregates of 10, 25, 50, 100, 250 and 500 cells, resulting in aggregates with well-defined dimensions. The aggregates could easily be removed from the chips by flushing out or mild centrifugation (Figure 5.2A), after which they were used for further analysis. The average aggregate diameter directly correlated with the initial number of cells seeded per microwell and ranged between 29 and $105 \mu \mathrm{m}$ for INS-1E cells and between 28 and $93 \mu \mathrm{m}$ for MIN6 cells as shown in Figure 5.2B. Increasing the number of cells per microwell to 1000 resulted in unstable cell aggregates that were not suitable for further use (data not shown). In addition to MIN6 and INS-1E cell lines, our microwell platform supports the controlled reassembly of primary human islet cells. Human donor islets of Langerhans were dispersed into a single cell suspension ( $>95 \%$ viability, data not shown) and seeded at 100, 500 and 1000 cells per microwell to induce controlled aggregation similar to the previously mentioned cell lines. The resulting 
A
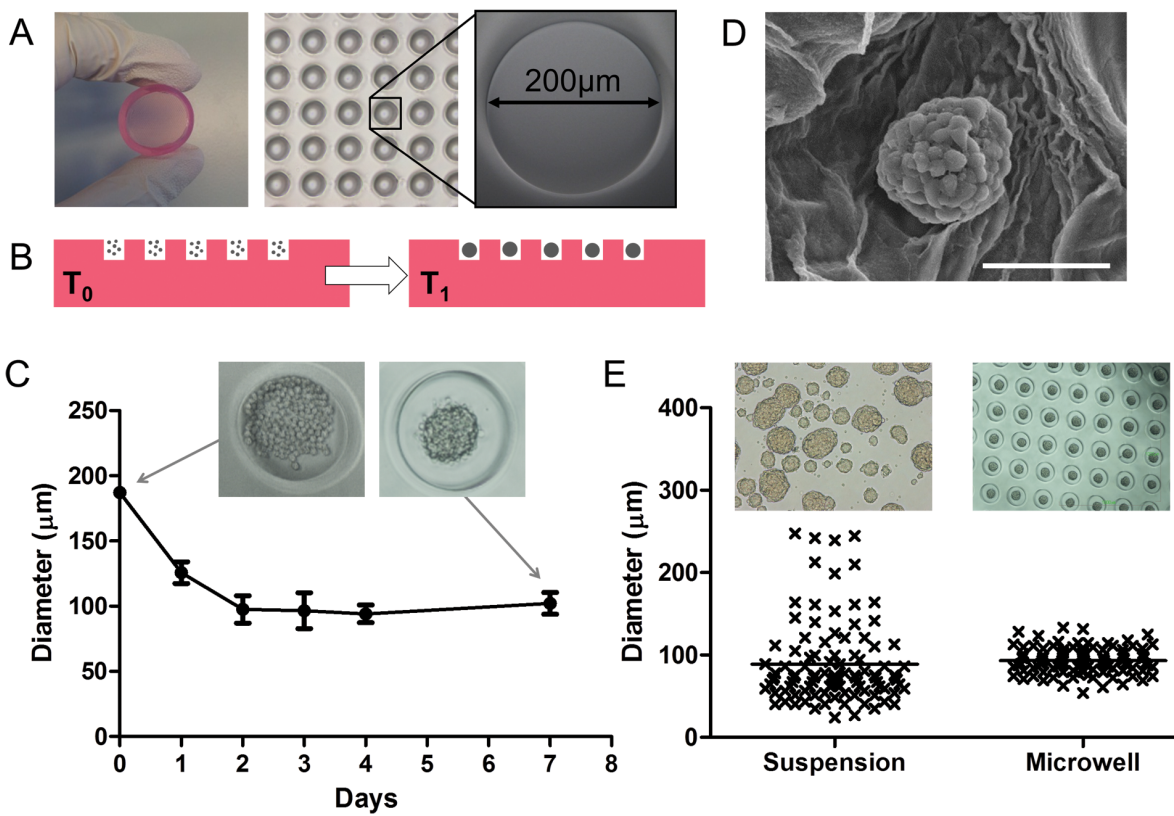

Figure 5.1: Fabrication and validation of microwell platform for controlled production of uniformly-sized aggregates. (A) Agarose microwell chip containing 2865 non-adherent wells with a diameter of $200 \mu \mathrm{m}$. (B) Schematic representation of controlled cell aggregation in agarose microwell chips. Single cells are seeded in suspension onto agarose microwell chips and briefly centrifuged to allow the cells to settle down in the microwells $\left(\mathrm{T}_{0}\right)$. In time, cells assemble and stable cell clusters are formed $\left(\mathrm{T}_{1}\right)$. (C) INS-1E cell aggregate formation in agarose microwells. Single INS-1E cells aggregate in the first 2 days of culture and form stable aggregates that were maintained up to 7 days of culture. (D) SEM image of an INS-1E cell aggregate that was embedded in agarose gel. Scale bar $=50 \mu \mathrm{m}$. (E) The microwell platform generates uniformly-sized INS-1E cell aggregates with less variability $(\mathrm{SD}=16)$ compared to conventional suspension culture $(\mathrm{SD}=49)(\mathrm{n}=100)$. 
A
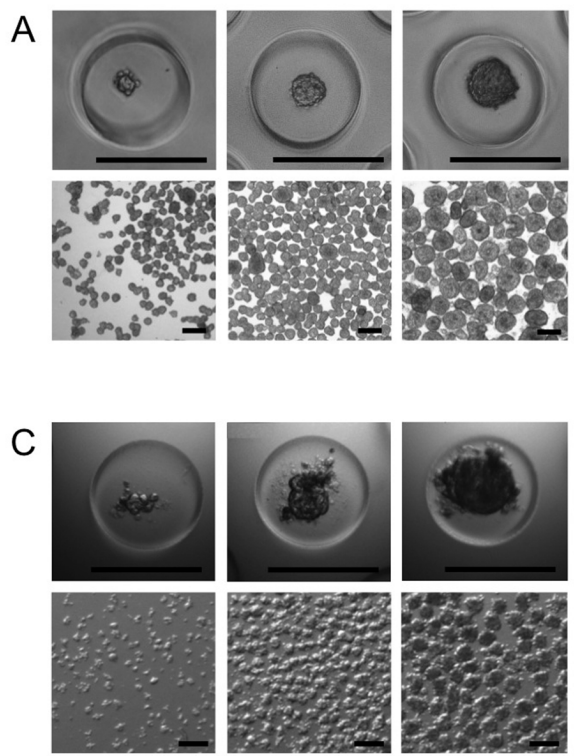
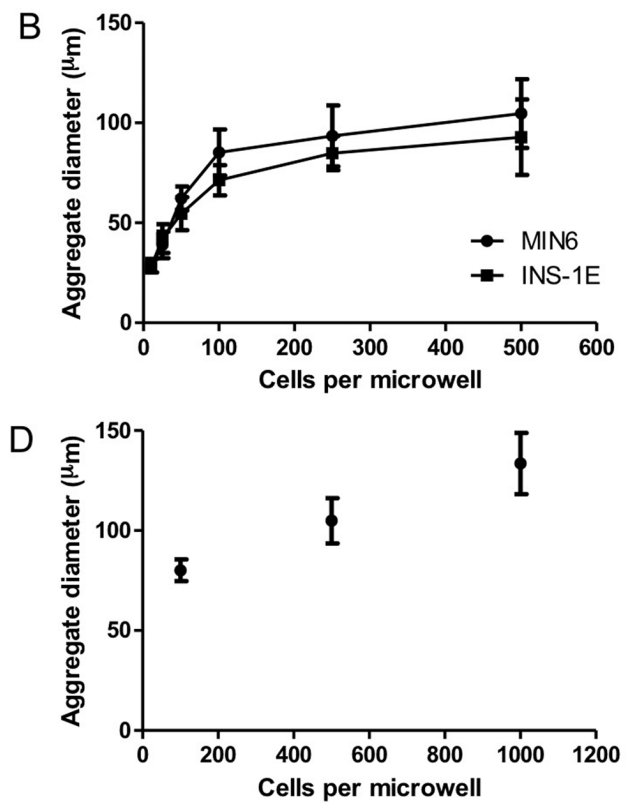

Figure 5.2: Seeding density determines aggregate size of insulinoma and human islet cell aggregates. (A) INS-1E cell aggregates of 50, 100, and 500 cells after 7 days of culture inside agarose microwells (top panel) and after flushing out of the chip (bottom panel). Scale bars represent $200 \mu \mathrm{m}$. (B) Correlation between number of INS-1E and MIN6 cells per microwell and diameter of obtained aggregates after 7 days of culture. Cells were seeded at $10,25,50,100,250$ and 500 cells per microwell. Each datapoint represents the measurement of at least 50 aggregates per condition. Error bars represent \pm SD. (C) Primary human islets were dispersed and single islet cells were seeded at 100, 500 and 1000 cells per microwell. Figures represent human islet cell aggregates inside the microwells (top panel) and after flushing them out of the chip (bottom panel) after 7 days of culture. Scale bars represent 200 $\mu \mathrm{m}$. (D) The diameter of human islet cell aggregates increased with increasing the number of cells seeded per well. Cells were seeded at 100, 500 and 1000 cells per microwell. At least 40 human islet cell aggregates were measured per condition. Datapoints represent the average values for 3 human donors. Error bars represent $\pm \mathrm{SD}$.

islet cell aggregates were uniform in size and remained intact after harvesting from the chips (Figure 5.2C). After 7 days of culture, the islet cell aggregates had an average diameter of $80 \pm 5.4,105 \pm 11.3$ and $134 \pm 15.3 \mu \mathrm{m}$, respectively (Figure 5.2D). Since the $200 \mu \mathrm{m}$ microwells could not fit more than 1000 cells, we created wells with a diameter of $400 \mu \mathrm{m}$. Increasing the number of cells in these microwells to 2000 resulted in uncontrolled formation of multiple smaller aggregates (data not shown). 


\subsubsection{INS-1E insulinoma cell aggregates are viable and functional}

To assess basic cell function within the aggregates in more detail, INS-1E cell aggregates were cultured in the agarose microwell platform up to 7 days after which their viability, protein expression and insulin secretion was assessed. Live/dead staining was performed on cells inside the microwell array and demonstrated a cell viability of at least $80 \%$ for all aggregate sizes (Figure 5.3A). Insulin-specific immunolabeling showed that INS-1E aggregates of various sizes consisting of 50, 100 and 500 INS1E cells still expressed insulin (Figure 5.3B). To test glucose-responsiveness, micro aggregates were challenged with a high-glucose concentration. The INS-1E cell aggregates secreted insulin upon high-glucose stimulus and returned to baseline after a second stimulation with low glucose. Aggregates of various sizes all responded in the same way (average stimulation index $=1.86 \pm 0.7$ ) (Figure 5.3C).

\subsubsection{Human islet cell aggregates are viable and functional}

Human islet cell aggregates of various sizes were further assessed for gene and protein expression, morphology and function. We measured the gene expression for INSULIN, $M A F A$ and $P D X 1$ at day 7 of culture. The expression levels in human islet cell aggregates were lower compared to intact control islets of the same donor. However, we found that increasing the number of cells per aggregate from 100 to 1000 showed increased expression INSULIN, MAFA and PDX1 although decreased compared to intact cultured islets (Figure 5.4A). Unlike intact human islets, in which beta-cells are randomly intermingled with alpha- and delta-cells [32-34], human islet cell aggregates showed a special architecture with glucagon-positive alpha-cells located in the core and insulin-positive beta-cells at the periphery of aggregates (Figure 5.4B). Importantly, glucose-stimulated insulin secretion assays demonstrated that human islet cell aggregates of 250 and 1000 cells responded similar to high-glucose as intact control islets of the same donor after 7 days of culture (Figure 5.4C). No significant differences were observed between the stimulation indices of human islet cell aggregates of 250 or 1000 cells ( $\mathrm{SI}=1.6$ and 2.6, respectively), and intact control islets $(\mathrm{SI}=2.1)$.

\subsection{Discussion}

We developed a microwell platform for the high-throughput generation of homogenous human islet cell aggregates. We studied the controlled generation of human islet cell aggregates and investigated beta-cell specific gene expression, morphology and function. Human islet cell aggregates of 1000 cells with a diameter of 100-150 $\mu \mathrm{m}$ showed an adequate insulin secretory response to a glucose stimulus, and $M A F A$, $P D X 1$ and INSULIN gene expression similar to human islets.

Human islet cell aggregates showed a specific core and mantle arrangement of alpha- and beta-cells, other than found in native human islets, which is in line with our previous observations [35]. Others have demonstrated that dispersed rat islet cells reassemble in culture and form islet-like aggregates with a core mantle organization similar to that of native rodent islets, which indicates that the signals required for this 

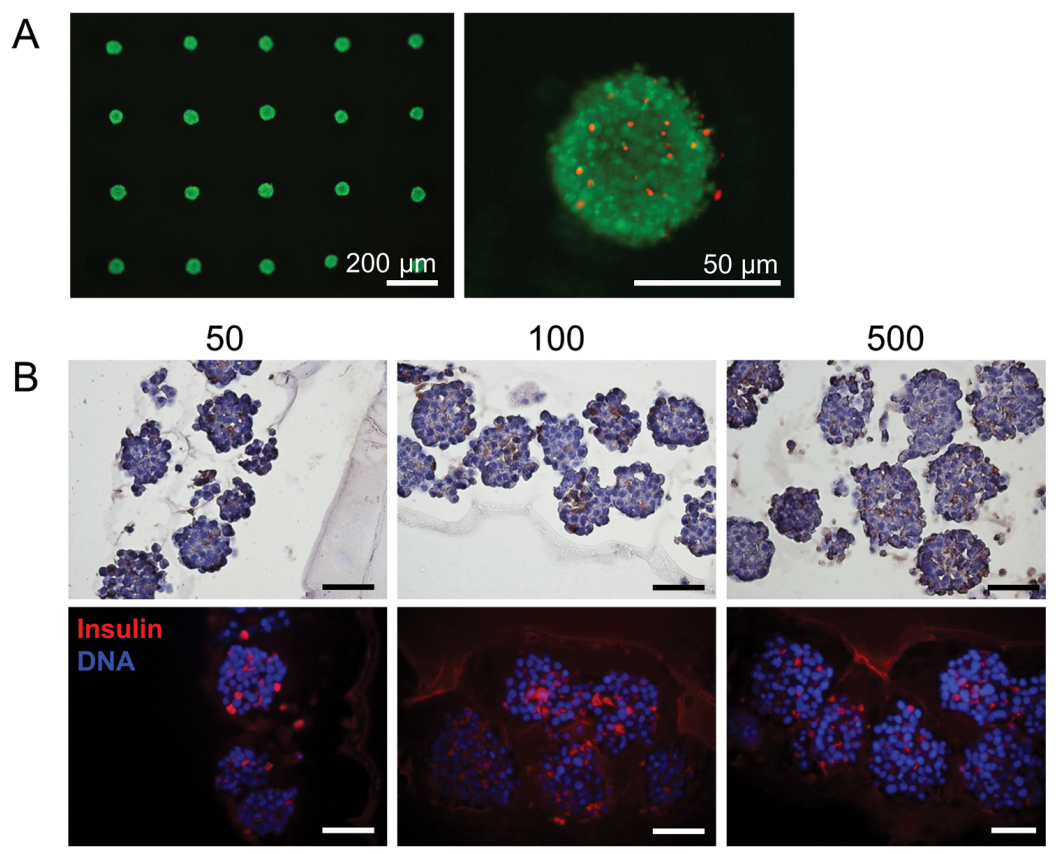

C

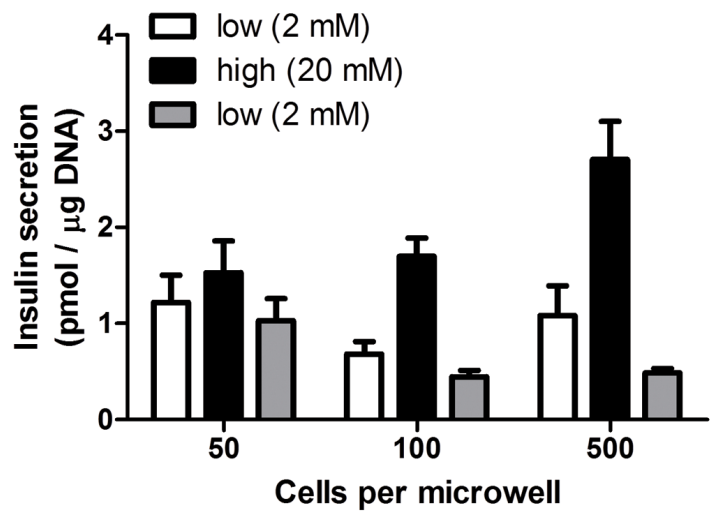

Figure 5.3: INS-1E cell aggregates of various sizes remain viable and functional up to 7 days of culture. (A) INS-1E cell aggregates were formed using agarose microwells. After 7 days of culture, a viability assay was performed to visualize living cells (green) and dead cells (red). (B) Histological evaluation of INS-1E cell aggregates of 50, 100 and 500 cells after 7 days of culture. Both DAB chromogen and fluorescent anti-insulin staining demonstrate that INS-1E cell aggregates of various sizes express insulin. Scale bars represent $50 \mu \mathrm{m}$. (C) Glucose-stimulated insulin secretion of INS-1E cell aggregates of various sizes measured after 7 days of culture $(n=3 \times 100$ aggregates/condition). Error bars represent \pm SD. 

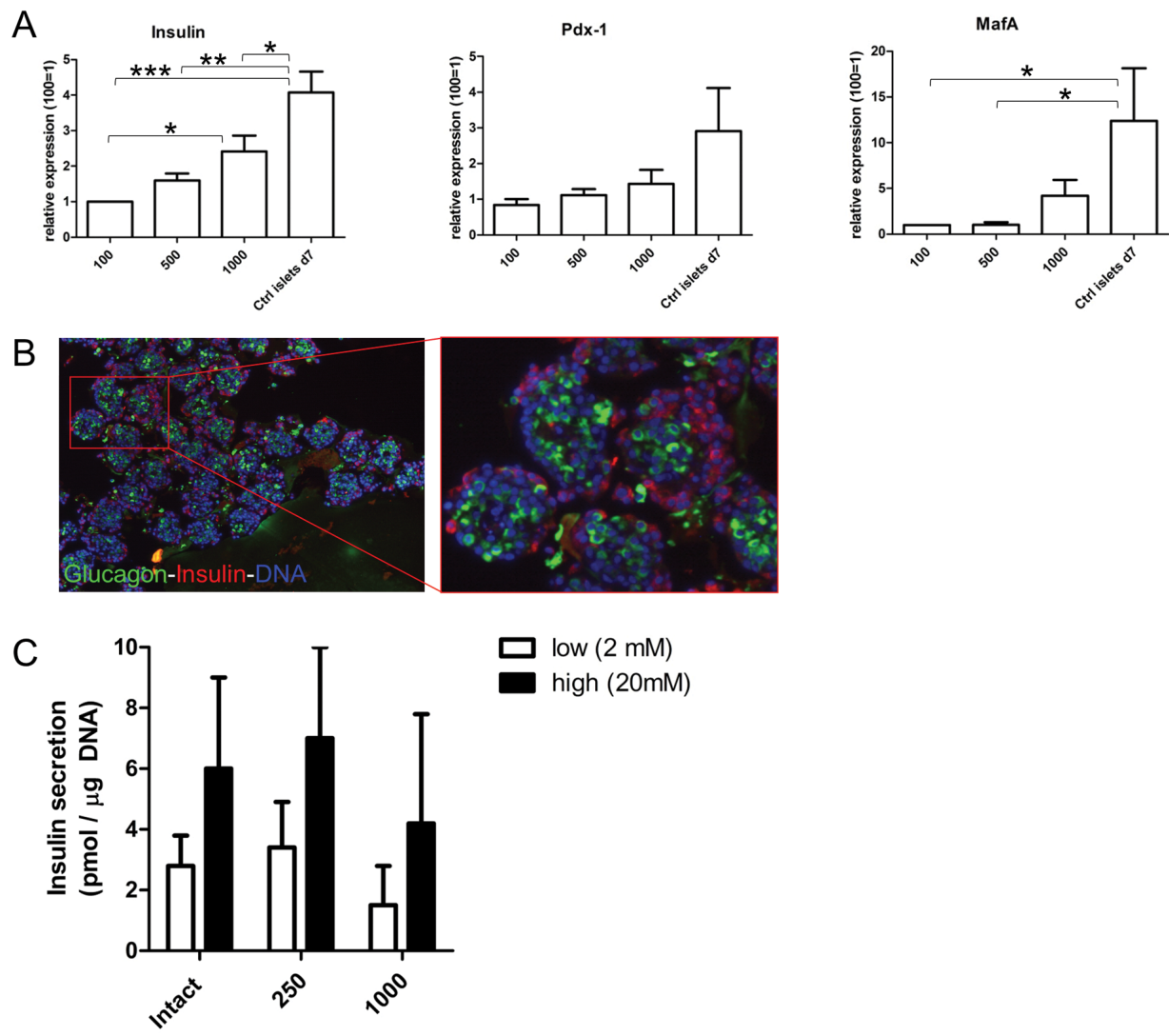

$\operatorname{low}(2 \mathrm{mM})$
$\operatorname{high}(20 \mathrm{mM})$

Figure 5.4: Gene- and protein expression of human islet cell aggregates. (A) Relative mRNA levels for INSULIN, PDX1 and MAFA expressed by intact control islets and human islet cell aggregates of 100, 500 or 1000 cells after 7 days of culture in microwell chips. (B) Human islet cell aggregates show a non-native architecture with beta-cells (red) located at the periphery and alpha-cells (green) in the core. (C) Glucose stimulated insulin secretion test was performed on human islet cell aggregates of 250 and 1000 cells and compared with intact control islets. Islet cells aggregates of both sizes show the same response as intact control islets. Error bars represent \pm SEM. 
specific organization are likely cell-mediated [36]. It has been shown that differential expression of distinct cell adhesion molecules (CAMs), more specifically neural cell adhesion molecule (N-CAM), is responsible for the establishment and maintenance of rat islet architecture [37-39]. Our findings suggest that in contrast to rodent islet cells, the unique cellular organization of human islet cells is not or not solely mediated by the islet cells themselves. Despite their non-native architecture, the insulin secretory response of human islet cell aggregates of various sizes suggests that islet dispersion and reassembly does not affect their glucose-responsiveness.

Controlled cell aggregation in our microwell platform was optimized using MIN6 and INS-1E cell lines and resulted in uniformly sized cell aggregates with a small variability in diameter, compared to heterogeneous cell aggregation in conventional suspension culture. Using our microwells, aggregate dimensions could accurately be controlled by changing the initial cell seeding density, resulting in cell aggregates with pre-defined dimensions. This is in line with other studies demonstrating the use of poly(ethylene glycol) (PEG) microwells for controlled aggregation of MIN6 beta-cells and the aggregation of dispersed rat islet cells in glass micromolds [24, 26]. Our wells were micromolded in agarose, which is a polysaccharide that is cheap, non-toxic and easy to use. In addition, cells do not adhere to the material that supports cell aggregation. Since no special equipment is required, the microwells can be used in all basic research laboratories in standard tissue culture plates. In addition, the negative PDMS molds can easily be varied to create microwells of various sizes and shapes, and are re-usable which makes for a fast and sustainable low-cost fabrication procedure. The maximum aggregate diameter that could be obtained using our platform was limited to approximately $150 \mu \mathrm{m}$, as increasing the number of cells above 1000 cells per aggregate resulted in unstable aggregates. Controlling cell aggregation using this platform aids in reducing the variability and increase the reproducibility of experimental results.

Regarding their endocrine function, INS-1E cell aggregates showed an insulin secretory response upon stimulation with high glucose, indicating that the aggregates were glucose-responsive. This is in line with an extensive follow-up study by Merglen et al., reporting that INS-1E cells and primary rat islets share similar insulin secretory kinetics, underlining the potential of INS-1E cell aggregates as a valuable model for research purposes [28]. We did not observe a correlation between aggregate size and function, which is in agreement with other studies using MIN6 cells [24].

\subsection{Conclusions}

In conclusion, our agarose microwell platform provides a platform to create human islet cell aggregates with optimal dimensions. This three-dimensional shape has been shown to be critical for optimal beta-cell functioning [40]. The homogenous human islet cell aggregates can easily be harvested from the microwells in high quantities, after which they remain stable and can be used for further investigation or transplantation. Human islet cell aggregates with a diameter of 100-150 $\mu \mathrm{m}$ showed an adequate insulin secretory response to a glucose stimulus, and MAFA, PDX1 and IN- 
SULIN gene expression similar to human islets. Furthermore, our microwell platform provides a valuable research tool for a variety of applications, such as high-throughput in vitro compound screening. 


\section{References}

1. Langer, R.M., Islet transplantation: lessons learned since the Edmonton breakthrough. Transplant Proc, 2010. 42(5): p. 1421-4.

2. Ryan, E.A., et al., Five-year follow-up after clinical islet transplantation. Diabetes, 2005. 54(7): p. 2060-9.

3. Williams, S.J., et al., Diffusion into human islets is limited to molecules below 10 kDa. Tissue Cell, 2012. 44(5): p. 332-41.

4. Lehmann, R., et al., Superiority of small islets in human islet transplantation. Diabetes, 2007. 56(3): p. 594-603.

5. O'Sullivan, E.S., et al., Rat islet cell aggregates are superior to islets for transplantation in microcapsules. Diabetologia, 2010. 53(5): p. 937-45.

6. Nam, K.H., et al., Size-based separation and collection of mouse pancreatic islets for functional analysis. Biomed Microdevices, 2010. 12(5): p. 865-74.

7. Lin, C.C. and K.S. Anseth, Cell-cell communication mimicry with poly(ethylene glycol) hydrogels for enhancing beta-cell function. Proc Natl Acad Sci U S A, 2011. 108(16): p. 6380-5.

8. Brereton, H.C., et al., Homotypic cell contact enhances insulin but not glucagon secretion. Biochem Biophys Res Commun, 2006. 344(3): p. 995-1000.

9. Hauge-Evans, A.C., et al., Role of adenine nucleotides in insulin secretion from MIN6 pseudoislets. Mol Cell Endocrinol, 2002. 191(2): p. 167-76.

10. Kelly, C., et al., Comparison of insulin release from MIN6 pseudoislets and pancreatic islets of Langerhans reveals importance of homotypic cell interactions. Pancreas, 2010. 39(7): p. 1016-23.

11. Luther, M.J., et al., MIN6 beta-cell-beta-cell interactions influence insulin secretory responses to nutrients and non-nutrients. Biochem Biophys Res Commun, 2006. 343(1): p. 99-104.

12. Halban, P.A., et al., The possible importance of contact between pancreatic islet cells for the control of insulin release. Endocrinology, 1982. 111(1): p. 86-94.

13. Wojtusciszyn, A., et al., Insulin secretion from human beta cells is heterogeneous and dependent on cell-to-cell contacts. Diabetologia, 2008. 51(10): p. 1843-52.

14. Pipeleers, D., et al., Glucose-induced insulin release depends on functional cooperation between islet cells. Proc Natl Acad Sci U S A, 1982. 79(23): p. 7322-5.

15. Cavallari, G., et al., Rat pancreatic islet size standardization by the "hanging drop" technique. Transplant Proc, 2007. 39(6): p. 2018-20.

16. Cerdan, C., S.H. Hong, and M. Bhatia, Formation and hematopoietic differentiation of human embryoid bodies by suspension and hanging drop cultures. Curr Protoc Stem Cell Biol, 2007. Chapter 1: p. Unit 1D 2.

17. Wang, X. and P. Yang, In vitro differentiation of mouse embryonic stem (mES) cells using the hanging drop method. J Vis Exp, 2008(17).

18. Mendelsohn, A.D., et al., Patterning of mono- and multilayered pancreatic betacell clusters. Langmuir, 2010. 26(12): p. 9943-9.

19. Mendelsohn, A.D., et al., Size-controlled insulin secreting cell clusters. Acta Biomater, 2012.

20. Moeller, H.C., et al., A microwell array system for stem cell culture. Biomaterials, 
2008. 29(6): p. 752-63.

21. Xu, Y., et al., Rapid fabrication of a microdevice with concave microwells and its application in embryoid body formation. Biomicrofluidics, 2012. 6(1): p. 165041650411.

22. Khademhosseini, A., et al., Co-culture of human embryonic stem cells with murine embryonic fibroblasts on microwell-patterned substrates. Biomaterials, 2006. 27(36): p. $5968-77$.

23. Moreira Teixeira, L.S., et al., High throughput generated micro-aggregates of chondrocytes stimulate cartilage formation in vitro and in vivo. Eur Cell Mater, 2012. 23: p. 387-99.

24. Bernard, A.B., C.C. Lin, and K.S. Anseth, A Microwell Cell Culture Platform for the Aggregation of Pancreatic beta-Cells. Tissue Eng Part C Methods, 2012.

25. Gallego-Perez, D., et al., Micro/nanoscale technologies for the development of hormone-expressing islet-like cell clusters. Biomed Microdevices, 2012. 14(4): p. $779-89$.

26. Ramachandran, K., et al., Engineering Islets for Improved Performance by Optimized Reaggregation in a Micromold. Tissue Eng Part A, 2012.

27. Lilla, V., et al., Differential gene expression in well-regulated and dysregulated pancreatic beta-cell (MIN6) sublines. Endocrinology, 2003. 144(4): p. 1368-79.

28. Merglen, A., et al., Glucose sensitivity and metabolism-secretion coupling studied during two-year continuous culture in INS-1E insulinoma cells. Endocrinology, 2004. 145(2): p. 667-78.

29. Rivron, N.C., et al., Tissue deformation spatially modulates VEGF signaling and angiogenesis. Proc Natl Acad Sci U S A, 2012. 109(18): p. 6886-91.

30. Ravassard, P., et al., A genetically engineered human pancreatic beta cell line exhibiting glucose-inducible insulin secretion. J Clin Invest, 2011. 121(9): p. 3589-97. 31. Skelin, M., M. Rupnik, and A. Cencic, Pancreatic beta cell lines and their applications in diabetes mellitus research. ALTEX, 2010. 27(2): p. 105-13.

32. Bosco, D., et al., Unique arrangement of alpha- and beta-cells in human islets of Langerhans. Diabetes, 2010. 59(5): p. 1202-10.

33. Brissova, M., et al., Assessment of human pancreatic islet architecture and composition by laser scanning confocal microscopy. J Histochem Cytochem, 2005. 53(9): p. 1087-97.

34. Cabrera, O., et al., The unique cytoarchitecture of human pancreatic islets has implications for islet cell function. Proc Natl Acad Sci U S A, 2006. 103(7): p. 23349.

35. Spijker, H.S., et al., Conversion of mature human beta-cells into glucagonproducing alpha-cells. Diabetes, 2013.

36. Halban, P.A., et al., Spontaneous reassociation of dispersed adult rat pancreatic islet cells into aggregates with three-dimensional architecture typical of native islets. Diabetes, 1987. 36(7): p. 783-90.

37. Cirulli, V., et al., Expression of neural cell adhesion molecule (N-CAM) in rat islets and its role in islet cell type segregation. J Cell Sci, 1994. 107 ( Pt 6): p. $1429-36$.

38. Esni, F., et al., Neural cell adhesion molecule (N-CAM) is required for cell type 
segregation and normal ultrastructure in pancreatic islets. J Cell Biol, 1999. 144(2): p. $325-37$.

39. Rouiller, D.G., V. Cirulli, and P.A. Halban, Differences in aggregation properties and levels of the neural cell adhesion molecule (NCAM) between islet cell types. Exp Cell Res, 1990. 191(2): p. 305-12.

40. Chowdhury, A., et al., Functional differences between aggregated and dispersed insulin-producing cells. Diabetologia, 2013. 56: p. 1557-68. 



\section{Chapter 6}

\section{Size-controlled cluster formation of human pancreatic islet cells on protein patterned biomaterials}

Janneke Hilderink, Jenny Brinkmann, Jordi Cabanas, Erhan Bat, Eelco de Koning, Marten Engelse, Clemens van Blitterswijk, Pascal Jonkheijm, Marcel Karperien, Aart van Apeldoorn 


\begin{abstract}
Inducing cell-to-cell interactions between pancreatic islet cells is imperative for islet function on the long term. Cell aggregation by conventional suspension culture results in a heterogeneous aggregate population. Controlled and reproducible production of three-dimensional cell clusters could overcome this disadvantage. This study describes the use of microcontact printing to efficiently produce uniform patterns of fibronectin on PDMS and PEOT/PBT biomaterials. We showed the controlled generation of cell clusters of INS-1E cells alone and in co-culture with HUVECs. Patterning of dispersed human islet cells resulted in uniform cell clusters with cellular architecture and glucose-responsiveness similar to intact human islets. This method provides a tool to produce uniform human islet cell clusters with optimal dimensions. In addition, we showed that islet morphology of intact human islets immobilized on microcontact printed substrates was preserved. The use of microcontact printing may help to develop an optimal scaffold for pancreatic islet transplantation for patients with type 1 diabetes.
\end{abstract}




\subsection{Introduction}

Type 1 diabetes is an autoimmune disorder characterized by destruction of islets of Langerhans in the pancreas. The current standard of care for type 1 diabetes patients consists of daily insulin injections, but there have been significant efforts to regulate blood glucose levels by intrahepatic transplantation of donor islets of Langerhans. Although promising, donor scarcity and severe islet loss shortly after transplantation are major factors limiting the widespread clinical use of pancreatic islet transplantation $[1,2]$. During the islet isolation procedure, cell to matrix (ECM) interactions are disrupted and internal islet vascularization is destroyed. As a result of the latter, nutrient transport in isolated islets depends on passive diffusion which is limited to around $150 \mu \mathrm{m}$ [3-5]. Insufficient nutrient supply to the islet core strongly inhibits long-term survival of islets grafts. Especially larger islets (diameter $>150 \mu \mathrm{m}$ ) are susceptible to central necrosis due to a lack of oxygen [6-8]. However, very small cell clusters are also not favorable because beta-cells require close cell-cell contact to secrete insulin in response to a high-glucose stimulus [9-11]. These findings emphasize the need to produce islet cell clusters of optimal dimensions that are large enough to maintain beta-cell function, yet small enough to prevent severe cell death.

Microcontact printing enables the immobilization of defined patterns of cell-adhesive proteins on a surface. This technique has been widely used to produce cell patterns of various cell types [12-15]. Recent studies have reported the patterning of insulin producing INS-1E insulinoma cells $[16,17]$. They show that larger clusters $(120 \mu \mathrm{m})$ of INS-1E cells on microcontact printed coverslips secrete insulin more rapidly than smaller cell clusters $(60 \mu \mathrm{m})[17]$.

In this study we used microcontact printing to produce size-controlled clusters of approximately $100 \mu \mathrm{m}$ in diameter of cell lines and human donor islet cells on different biomaterials. We hypothesize that by controlling reassembly of dispersed human islet cells we can create islets with optimal dimensions. In addition, we demonstrated confined immobilization of intact human donor islets on microcontactprinted substrates, hypothesizing that this will help to maintain islet morphology and prevent islet aggregation, thereby preserving nutritional and oxygen flow to the cells.

\subsection{Materials and methods}

\subsubsection{Cell culture}

INS-1E rat insulinoma cells (kindly provided by Dr. B. Guigas, LUMC, Leiden, The Netherlands and Dr. P. Maechler, University Medical Center, Geneva, Switzerland) [18] were cultured in RPMI with $2.05 \mathrm{mM}$ L-glutamine (Invitrogen) supplemented with $5 \%$ FBS, $100 \mathrm{U} / \mathrm{ml}$ streptomycin, $100 \mu \mathrm{g} / \mathrm{ml}$ penicillin, $10 \mathrm{mM}$ HEPES, $1 \mathrm{mM}$ sodium pyruvate, $50 \mu \mathrm{M}$ freshly added $\beta$-mercaptoethanol. Human umbilical vein endothelial cells (HUVECs), purchased from Cambrex (East Rutherford, NJ), were cultured in endothelial growth medium-2 (Cambrex). HUVECs from passage 3 were used for the experiments. All cell cultures were maintained at $37^{\circ} \mathrm{C}$ in humidified air 
containing $5 \% \mathrm{CO}_{2}$. Medium was refreshed every 3 to 4 days and cells were replated when $80 \%$ confluency was reached.

\subsubsection{Human islet culture}

Human islets of Langerhans that could not be used for clinical islet transplantation were provided by the Leiden University Medical Center, Leiden, The Netherlands. Human islets were dispersed into single cells by adding $0.025 \%$ trypsin solution containing $10 \mu \mathrm{g} / \mathrm{mL}$ DNase (Pulmozyme, Genentech). Intact human islets and human islet cells were seeded onto microcontact printed substrates for controlled immobilization. Cells and islets were cultured in CMRL 1066 medium (5.5 mM glucose) (Mediatech) supplemented with $10 \% \mathrm{FCS}, 20 \mu \mathrm{g} / \mathrm{ml}$ ciprofloxacin, $50 \mu \mathrm{g} / \mathrm{ml}$ gentamycin, 2 $\mathrm{mM}$ L-glutamin, $0.25 \mu \mathrm{g} / \mathrm{ml}$ fungizone, $10 \mathrm{mM}$ HEPES and $1.2 \mathrm{mg} / \mathrm{ml}$ nicotinamide. Cultures were maintained at $37^{\circ} \mathrm{C}$ in a $5 \% \mathrm{CO}_{2}$ humidified atmosphere. Medium was refreshed every 3 to 4 days.

\subsubsection{Biomaterials}

Polydimethylsiloxane (PDMS) and Poly(ethylene oxide terephthalate)-poly(butylene terephthalate) (PEOT/PBT) block copolymer were used as substrates for microcontact printing. PDMS is an optically clear inert biomaterial that is widely used for cell culture applications and commonly used for microfluidic chips [19]. PEOT/PBT block copolymer is a biodegradable polymer that consists of two building blocks, hydrophilic PEOT and hydrophobic PBT. We used 4000PEOT30PBT70 with a PEOT/PBT weight ratio of 30/70 and initial PEG blocks with a molecular weight of $4000 \mathrm{~g} / \mathrm{mol}$. PEOT/PBT polymer films were fabricated by solvent casting, as described before by our group [20].

\subsubsection{Fabrication of microcontact printed substrates}

Silicon wafer-based masters with etched structures were prepared by UV photolithography. An inverse pattern of the silicon wafer was prepared by casting of a 1:10 w/w mixture of Sylgaard 184 (Dow Corning, USA) elastomer base and subsequent baking at 60 degrees overnight to obtain stamps of Poly(dimethysiloxane) (PDMS). PDMS stamps were first oxidized in an $\mathrm{O}_{2}$-plasma reactor (Plasma-Prep II plasma etcher, SPI supplies, USA) at an oxygen pressure of 1.0 bar and a current of $40 \mathrm{~mA}$ for 15-20 sec. The stamps were incubated with a solution of $100 \mu \mathrm{g} / \mathrm{mL}$ fibronectin including $5-10 \%$ rhodamine fibronectin (Cytoskeleton, Inc., USA) in PBS and incubated for $30 \mathrm{~min}$ at room temperature. The excess of inking solution was then removed, the stamps were dried with a flow of dry $\mathrm{N}_{2}$ and brought into conformal contact with the UV-ozone treated (60 min) epoxide-terminated biomaterial for $30 \mathrm{~min}$. After printing, the substrates were baked for $30 \mathrm{~min}$ at $37^{\circ} \mathrm{C}$. Background blocking was done in $10 \% \mathrm{w} / \mathrm{v}$ Pluoronic F108 in PBS for 3 hours at room temperature. Substrates were sterilized by incubating in $70 \%$ ethanol for 15 minutes, and washed with PBS. 
Fluorescence intensity profiles were obtained by measuring the pixel intensity across the image, using ImageJ software.

\subsubsection{Cell seeding on microcontact printed substrates}

To immobilize cells on biomaterials, INS-1E cells, HUVECs and dispersed human islet cells were resuspended in fresh medium and seeded onto microcontact printed substrates at $2,5,10$ or $100 \times 10^{4}$ cells $/ \mathrm{cm}^{2}$. To immobilize islets on biomaterials, intact human islets were seeded at 125 islets $/ \mathrm{cm}^{2}$. As a control, cells and islets were seeded on tissue culture plastic (TCP) or full fibronectin-coated PDMS. Medium was refreshed every 2-3 days. Samples were analyzed after 7 or 14 days of culture. To measure the average INS-1E cell cluster diameter, microscopic images were taken and cell cluster diameters were quantified using ImageJ. At least 50 cell clusters were measured. The average INS-1E cell cluster height was determined by making z-stacks using confocal fluorescence microscopy. Distribution of cells in co-culture conditions was quantified by manually counting labeled cells. At least 20 spots of 3 different samples were counted per condition.

\subsubsection{Scanning Electron Microscopy}

Samples were fixed in $4 \%(\mathrm{w} / \mathrm{v})$ paraformaldehyde and prepared for scanning electron microscopy by dehydration in increasing concentrations of ethanol (1 hour each step) and dried using critical point dryer equipment (CPD 030, BAL-TEC). The samples were sputter-coated with gold and imaged using a scanning electron microscope (XL30 ESEM-FEG, Philips).

\subsubsection{Cell viability}

Cell viability was assessed on day 7 by staining the cells with $6 \mu \mathrm{M}$ ethidium homodimer and $1 \mu \mathrm{M}$ calcein using a LIVE/DEAD Viability/Toxicity Kit (Invitrogen) and visualized using fluorescence microscopy (Nikon Eclipse E600). Viable cells were stained green, and DNA of dead cells was stained red. Staining was quantified as percentage of viable cells per total cell number, counting at least 50 cells per condition.

\subsubsection{Immunohistochemistry}

Human islets, human islet cell clusters and INS-1E cell clusters were fixed in $4 \%$ $(\mathrm{w} / \mathrm{v})$ paraformaldehyde and washed in PBS. Cells were permeabilized with $0.25 \%$ Triton-X 100/10 mM PBS and whole-mount stained using specific antibodies. For immunohistochemical labeling of insulin, blocking was done using dual endogenous enzyme block (DAKO, Denmark). Sections were incubated with rabbit anti-human insulin polyclonal antibody (1:400, Santa-Cruz) for 1 hour at $21^{\circ} \mathrm{C}$, followed by subsequent washing steps in PBS and $1 \%(\mathrm{v} / \mathrm{v})$ BSA/PBS and incubated with HRP-goat anti-rabbit IgG secondary antibody (1:100, DAKO) for 1 hour at $21^{\circ} \mathrm{C}$. Sections were then rinsed in PBS and incubated for 4 minutes with DAB liquid chromogen 
system (DAKO), which yields a brown color. Counterstaining was performed using hematoxylin (Gills hematoxylin no. 3, Sigma-Aldrich) according to the manufacturers protocol and samples were visualized using a Nikon Eclipse E600 microscope. For fluorescent immunolabeling of insulin and glucagon, blocking was done with $0.1 \%$ $(\mathrm{w} / \mathrm{v})$ normal donkey serum/PBS for 1 hour and antibodies were diluted in $1 \%(\mathrm{v} / \mathrm{v})$ lamb serum/PBS. Primary antibodies used were: 1:100 rabbit-anti-glucagon (Vector Labs) overnight at $4{ }^{\circ} \mathrm{C}$, and 1:200 guinea pig-anti-insulin (ABCAM) for 1.5 hours at $21^{\circ} \mathrm{C}$. Secondary antibodies used were: 1:200 biotin donkey anti-rabbit (Jackson ImmunoResearch), 1:200 streptavidin-Alexa488 (Invitrogen), 1:400 rhodamine donkey anti-guinea pig (Jackson ImmunoResearch), all incubated for 1 hour at $21^{\circ} \mathrm{C}$. Actin staining was performed by incubating the samples for 30 minutes in Alexa fluor 488 phalloidin (Invitrogen), diluted 1:40 in PBS. Counterstaining was performed with $1 \mu \mathrm{g} / \mathrm{mL}$ 4'-6-diamidino-2-phenylindole (DAPI). Fluorescence was visualized using a Nikon Eclipse E600 microscope.

\subsubsection{Glucose stimulated insulin secretion test (GSIST)}

To test insulin secretory capacity, 3 groups of 50 human islets, human islet cell clusters or INS-1E cell clusters were hand-picked and transferred to an ultra-low attachment plate. INS-1E cell clusters were pre-incubated for 2 hours in glucose-free culture medium, followed by a 30 minutes pre-incubation in glucose free incubation buffer. Subsequently, the INS-1E cell clusters were incubated during 3 consecutive steps of 30 minutes in low glucose buffer $(2 \mathrm{mM})$, high-glucose buffer $(20 \mathrm{mM})$ and low glucose buffer $(2 \mathrm{mM})$ at $37^{\circ} \mathrm{C}$. Human islets and human islet cell clusters were pre-incubated for 1.5 hours in glucose-free buffer followed by 3 successive incubation steps of 1 hour in low glucose buffer $(2 \mathrm{mM})$, high-glucose buffer $(20 \mathrm{mM})$ and low glucose buffer $(2 \mathrm{mM})$ at $37^{\circ} \mathrm{C}$. Medium samples were collected after each incubation step and the concentration of secreted insulin was determined by ELISA according to the manufacturers protocol (Mercodia, Sweden). Absorbance was analyzed with Thermo Scientific Multiscan Go (450 nm). After GSIS, cell clusters were collected and analyzed for total DNA content using Quant-iT picogreen dsDNA assay kit (Invitrogen). Fluorescence was analyzed with a Perkin Elmer 1420 Multilabel counter (excitation $480 \mathrm{~nm}$, emission $520 \mathrm{~nm}$ ). Secreted insulin was normalized to the total DNA amount. As a measure of glucose-responsiveness, the stimulation index (SI) was calculated by dividing the amount of insulin released at high-glucose levels by the amount of insulin released at basal conditions.

\subsubsection{Circularity measurements}

The roundness of human islets of Langerhans was quantified by measuring the circularity, which is defined as the ratio between the circumference of a circle of equivalent area to the particle and the perimeter of the particle itself. The more spherical the particle, the closer its circularity is to 1 . The more elongated the particle, the lower its circularity. Circularity measurements are performed using ImageJ software. 


\subsection{Results}

\subsubsection{Fabrication of microcontact printed biomaterials for controlled cell aggregation}

To control beta-cell aggregation on a biomaterial, we created patterns of fibronectin on PDMS and PEOT/PBT block copolymer substrates by using microcontact printing. Fluorescence microscopy shows uniform patterns with $100 \mu \mathrm{m}$ diameter dots and $100 \mu \mathrm{m}$ spacing, of rhodamine-labeled fibronectin on both biomaterials (Figure 6.1A and B). The intensity of the fluorescent images is quantified and shown as intensity plots in Figure 6.1C. To study the formation of cell clusters on the microcontact printed surfaces, INS-1E cells were seeded at 100,000 cells $/ \mathrm{cm}^{2}$ and cultured up to 7 days. Brightfield images in Figure 6.1D and E show uniform cell cluster formation of live INS-1E cells on microcontact printed PDMS and PEOT/PBT block copolymer substrates.

\subsubsection{Seeding density determines dimensions of uniform INS-1E cell clusters}

To assess how the seeding density influences the dimensions of the formed clusters, INS-1E cells were seeded at various densities. Microcontact printed PDMS substrates were prepared and seeded with 2, 5, 10 and $100 \times 10^{4}$ cells $/ \mathrm{cm}^{2}$, resulting in cell clusters consisting of approximately 8, 20, 40 and 400 cells. After 7 days of culture, the cell cluster dimensions were determined. In all conditions, uniform cell cluster formation was observed. Low seeding densities resulted cell clusters of only one cell layer per spot with a diameter of $52 \pm 9 \mu \mathrm{m}$. When larger cell numbers were used, clusters of multiple cell layers were formed with an average diameter of $98 \pm 11 \mu \mathrm{m}$. Average cluster height ranged between 9 and $87 \mu \mathrm{m}$, depending on cell seeding density (Figure $6.2)$.

\subsubsection{Multilayered INS-1E cell clusters are viable and functional}

To study basic cell function of the cell clusters, INS-1E cell clusters were cultured for 7 days on microcontact printed PDMS after which their viability, protein expression and insulin secretion was assessed. Live/dead staining demonstrated a cell viability of at least $95 \%$ for the various seeding densities $\left(2,5,10\right.$ and $100 \times 10^{4}$ cells $/ \mathrm{cm}^{2}$ ) (Figure $6.3 \mathrm{~A})$. Insulin-specific immunolabeling showed that the INS-1E cell clusters expressed insulin (Figure 6.3B). To test their glucose-responsiveness, INS-1E cell cultures were challenged with a high-glucose concentration. The cells secreted insulin upon highglucose stimulus and went back to basal levels after a second stimulation with low glucose. The glucose-response of INS-1E cell clusters on microcontact printed PDMS $(\mathrm{SI}=2.5)$ was slightly increased compared to the glucose-responsiveness in the control conditions, in which INS-1E cells were cultured as 2D monolayers on either tissue culture plastic ( $\mathrm{SI}=4.6$ ) or on full fibronectin-coated PDMS ( $\mathrm{SI}=7.6)$ (Figure 6.3C). 

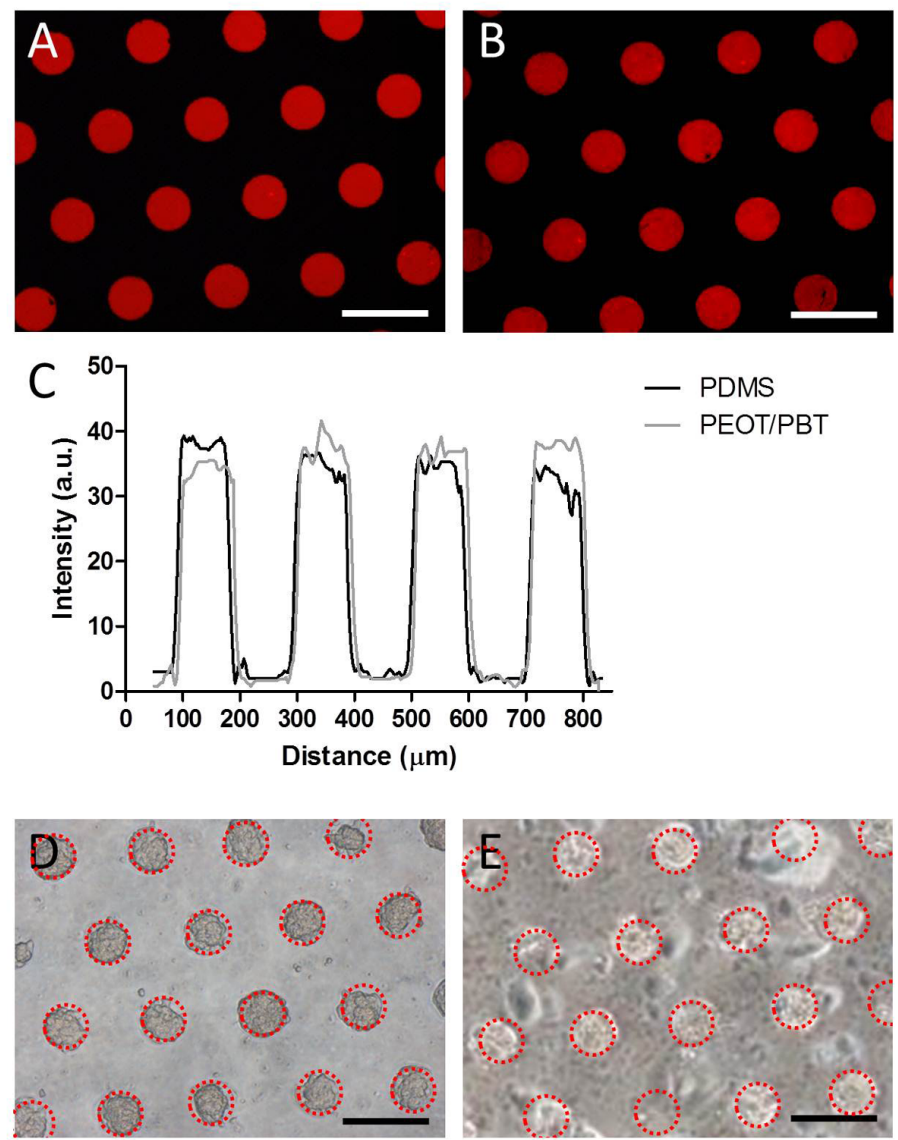

Figure 6.1: Fabrication of microcontact printed biomaterials for controlled production of uniformly sized aggregates. Fluorescence microscopy image of microcontact printed patterns of rhodaminelabeled fibronectin (100 $\mu \mathrm{m}$ diameter dots and $100 \mu \mathrm{m}$ spacing) on (A) poly(dimethylsiloxane) (PDMS), and (B) PEOT/PBT block copolymer. (C) Intensity profiles showing the intensity of the fluorescent images of microcontact printed polymers in A and B. Scale bars $=200 \mu \mathrm{m}$. Uniform INS-1E cell clusters were formed after 7 days of culture on (D) microcontact printed PDMS, and (E) microcontact printed PEOT/PBT copolymer. 
A

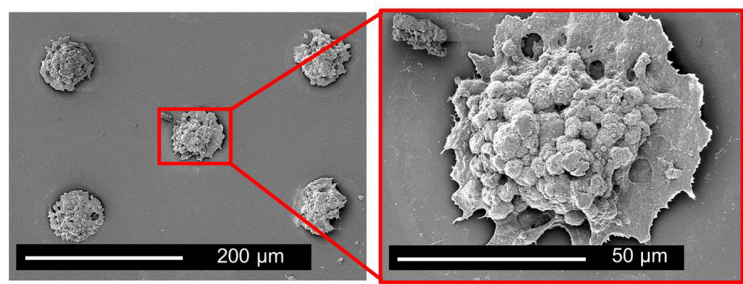

B
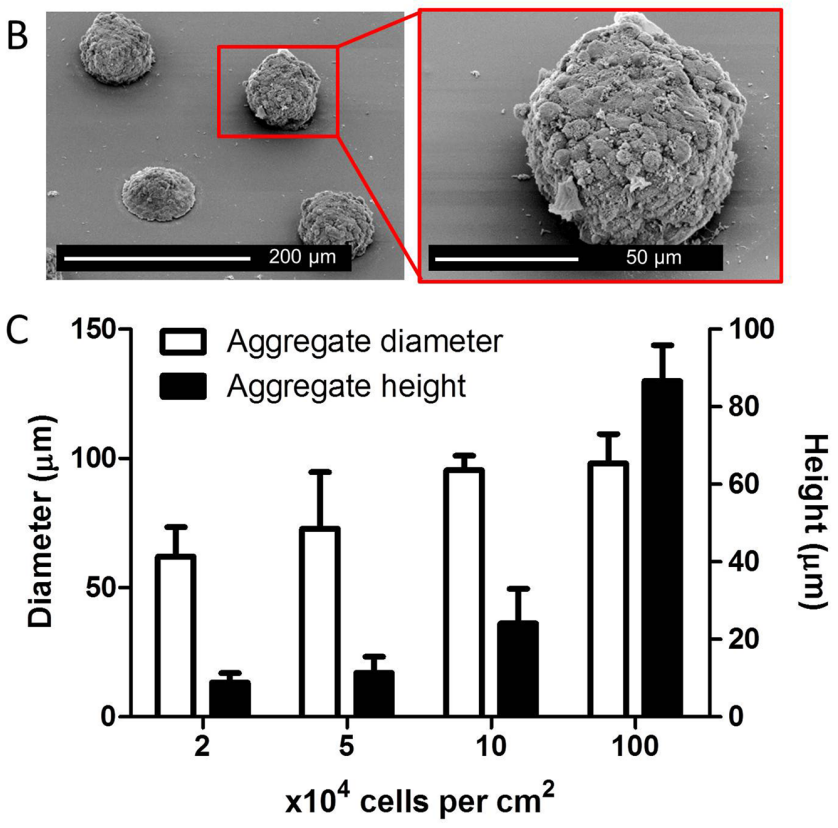

Figure 6.2: Seeding density determines dimensions of multilayered INS-1E cell clusters. (A) SEM images of INS- $1 \mathrm{E}$ cells $\left(5 \times 10^{4}\right.$ cells $\left./ \mathrm{cm}^{2}\right)$ cultured for 7 days on fibronectin-patterned PDMS (100 $\mu \mathrm{m}$ diameter dots and $100 \mu \mathrm{m}$ spacing). (B) SEM images of INS-1E cells $\left(100 \times 10^{4}\right.$ cells $\left./ \mathrm{cm}^{2}\right)$ cultured for 7 days on fibronectin-patterned PDMS. (C) Correlation between seeding density of INS-1E cells and diameter and height of obtained aggregates after 7 days of culture. Aggregate height was measured using confocal microscopy. Cells were seeded at 2, 5, 10 and $100 \times 10^{4}$ cells $/ \mathrm{cm}^{2}$. Error bars represent $\pm \mathrm{SD}$. 

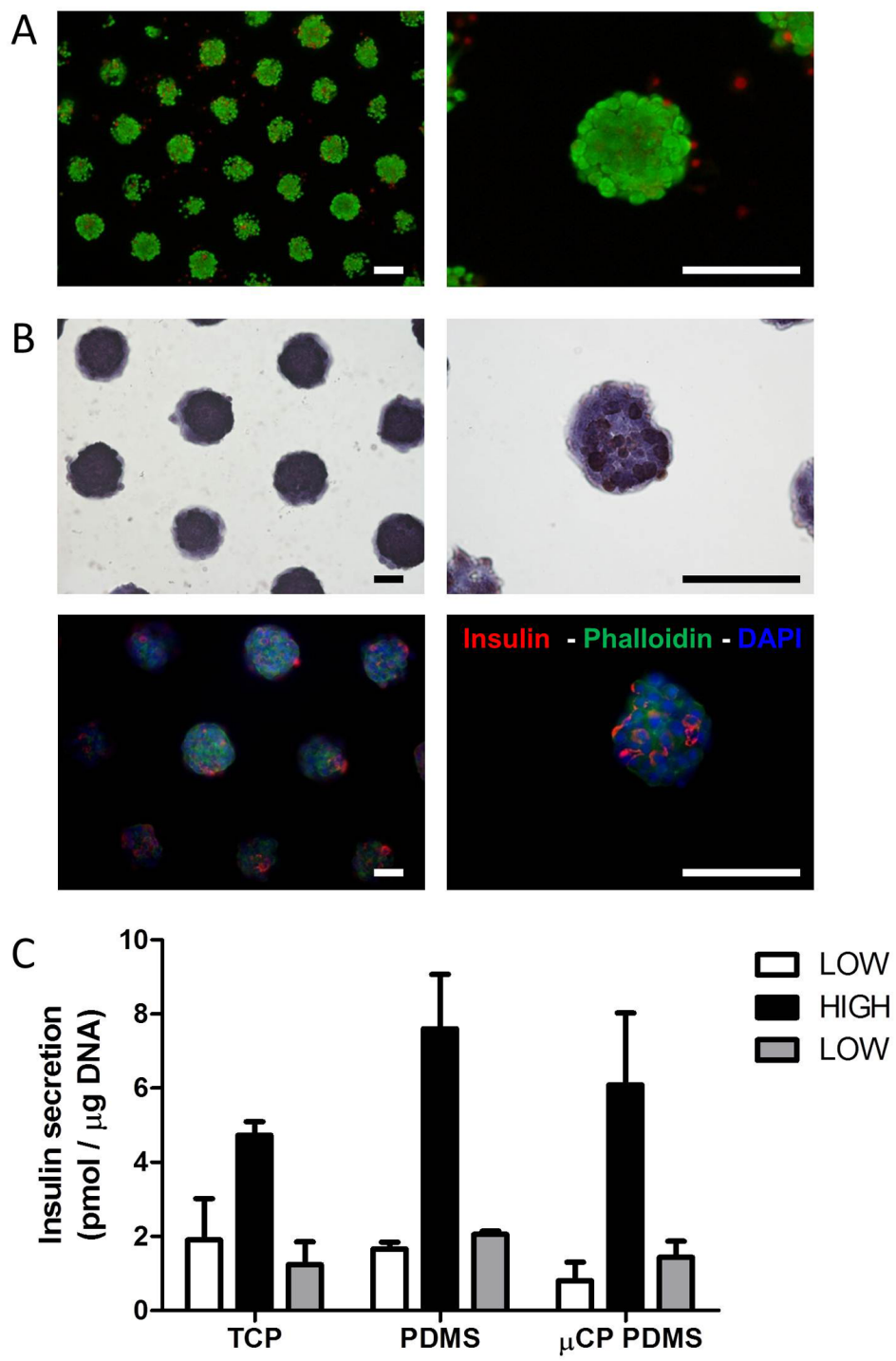

Figure 6.3: Multilayered INS-1E cell clusters remain viable and functional up to 7 days of culture. (A) INS-1E cell aggregates were formed by seeding single cells $\left(100,000\right.$ cells $\left./ \mathrm{cm}^{2}\right)$ on microcontact printed patterns of fibronectin on PDMS. After 7 days of culture, a viability assay was performed to visualize living cells (green) and dead cells (red), indicating that $>95 \%$ of cells are viable. (B) Histological evaluation, using DAB chromogen and fluorescent anti-insulin staining, demonstrates that INS-1E cell aggregates express insulin. (C) Glucose-stimulated insulin secretion of INS-1E cell aggregates on microcontact printed PDMS ( $\mu$ CP PDMS) was measured and compared with INS-1E monolayer cultures on PDMS fully coated with fibronectin and tissue culture plastic (TCP). Error bars represent \pm SD. Scale bars represent 100 $\mu \mathrm{m}$. 


\subsubsection{Self-assembly of co-cultures on microcontact printed PDMS}

Since proper vascularization is required for mature beta-cell function, we created cocultures of INS-1E beta-cells and human umbilical vein endothelial cells (HUVECs). Mixtures of various ratios of fluorescently-labeled INS-1E cells and HUVECs were seeded onto microcontact printed PDMS and cultured for 3 days. Self-assembly of the two cell types on microcontact printed PDMS is shown in Figure 6.4A. It was observed that in the 20/80 and 80/20 conditions, the different cell types seggregated. Image quantification showed that the majority of protein spots $(>90 \%)$ are homogeneously covered with either INS-1E cells or HUVECs. In contrast, the 50/50 cultures containing an equal number of both cell types showed mainly (92\%) heterogenous cell clusters containing a random mixture of INS-1E cells and HUVECs (Figure 6.4B). Figure $6.4 \mathrm{C}$ shows the percentages of red and green labelled cells in the various cultures, which reflects the initial ratios of cells that were seeded.

\subsubsection{Immobilization of human donor islets on microcontact printed PDMS}

Using microcontact printing, we restricted the cell binding area to immobilize human islets onto a biomaterial while maintaining their natural morphology. Human islets were seeded onto PDMS with $100 \mu \mathrm{m}$ diameter circles of microcontact printed fibronectin. As control conditions, islets were seeded 1) as free floating control in ultralow attachment plates, or 2) allowed to adhere to tissue culture plastic, or 3) cultured on full fibronectin-coated PDMS. After 14 days of culture, the free floating islets tended to fuse and form large aggregates composed of multiple islets. On tissue culture plastic and full-fibronectin coated PDMS, islets adhered in an uncontrolled manner and lost their natural rounded morphology. It was observed that on the microcontact printed PDMS substrates, islet cell adhesion was limited to the fibronectin spots (Figure 6.5A). Fluorescent immunolabeling indicated that in contrast to the control substrates, islets that were immobilized on microcontact printed PDMS did not change their morphology and no indication of cell outgrowth was found (Figure $6.5 \mathrm{~B})$. The spherical morphology of islets was quantified by measuring the islet circularity after 7 and 14 days of culture on the various substrates. Figure $6.5 \mathrm{C}$ shows that culturing islets on microcontact printed PDMS did not affect their natural round morphology. To study whether islet function was influenced by immobilizing the islets on microcontact printed PDMS, the islets were challenged with high-glucose after which the secreted insulin levels were measured. Glucose stimulated insulin secretion test (GSIS) revealed that the islets are able to produce insulin upon stimulation and that their glucose-responsiveness was not affected by immobilization onto the biomaterial when compared with the free floating control cultures (Figure 6.5D). 

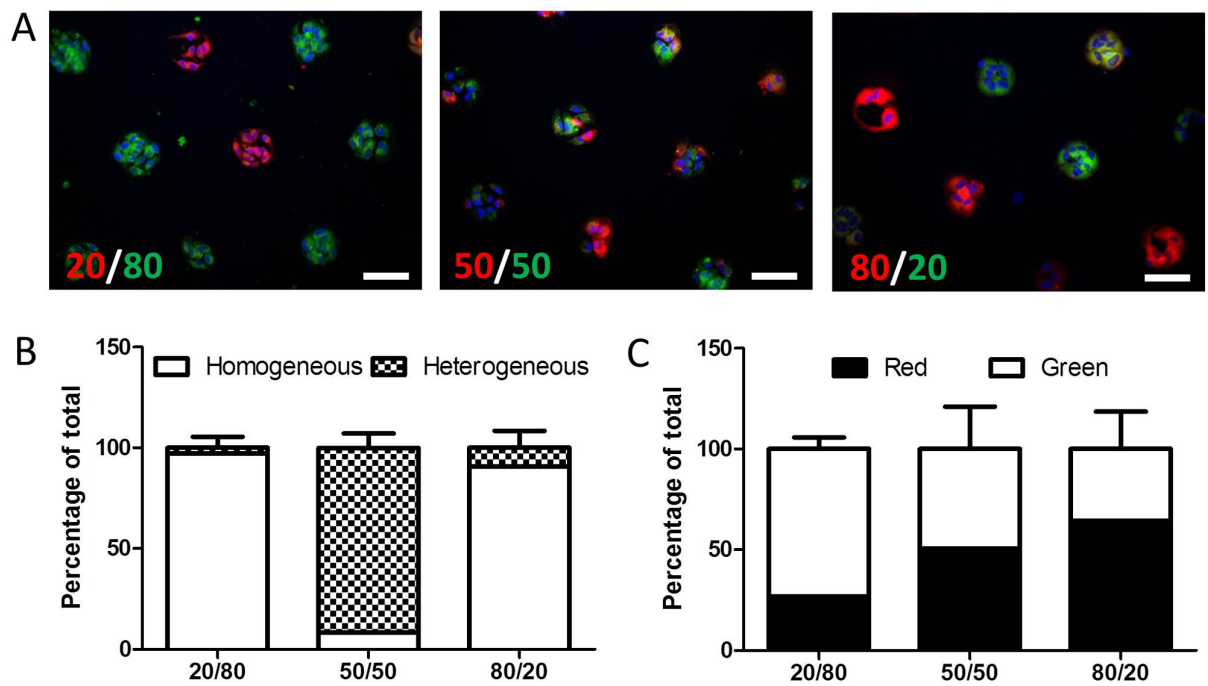

Figure 6.4: Co-cultures of INS-1E cells and HUVECs on fibronectinpatterned PDMS. (A) Co-culture aggregates were formed by seeding mixtures of fluorescently-labeled INS-1E cells (red) and HUVECs (green) on fibronectin-printed PDMS. Cells were seeded at 80/20, 50/50 and 20/80 INS$1 \mathrm{E} /$ HUVECs ratios. After 3 days of culture, self-assembly of the two cell types was visualized using fluorescence microscopy. Scale bars represent $100 \mu \mathrm{m}$. (B) Quantification of uniform spots (containing only 1 cell type) and mixed spots (containing a mix of both cell types). (D) Quantification of TRITC-labeled (red) INS-1E cells and FITC-labeled (green) HUVECs. Error bars represent $\pm \mathrm{SD}$.

\subsubsection{Reassembly of dispersed human islet cells on microcontact printed substrates}

In addition to controlled aggregation of cell lines and immobilization of intact human islets, microcontact printing can also be used for the controlled reassembly of human islet cells. Human donor islets were dispersed into a single cell suspension and seeded at $5 \times 10^{4}$ cells $/ \mathrm{cm}^{2}$ onto microcontact printed substrates, resulting in human islet cell clusters that were uniform in size, with an average diameter of $58 \pm 14 \mu \mathrm{m}$ at day 7 of culture (Figure 6.6A). Human islet cell clusters were further assessed for protein expression and function. Like intact human islets, the human islet cell clusters showed a typical heterogeneous cell distribution in which beta-cells were randomly intermingled with alpha- and other cells (Figure 6.6B). Image quantification indicated that approximately $30 \%$ of the total number cells were insulin-positive beta-cells, $25 \%$ were glucagon-positive alpha cells, and the remaining $45 \%$ were other (endocrine and exocrine) cells (Figure 6.6C). Glucose-stimulated insulin secretion assays demonstrated that after 7 days of culture, human islet cell clusters respond similar to a high-glucose 

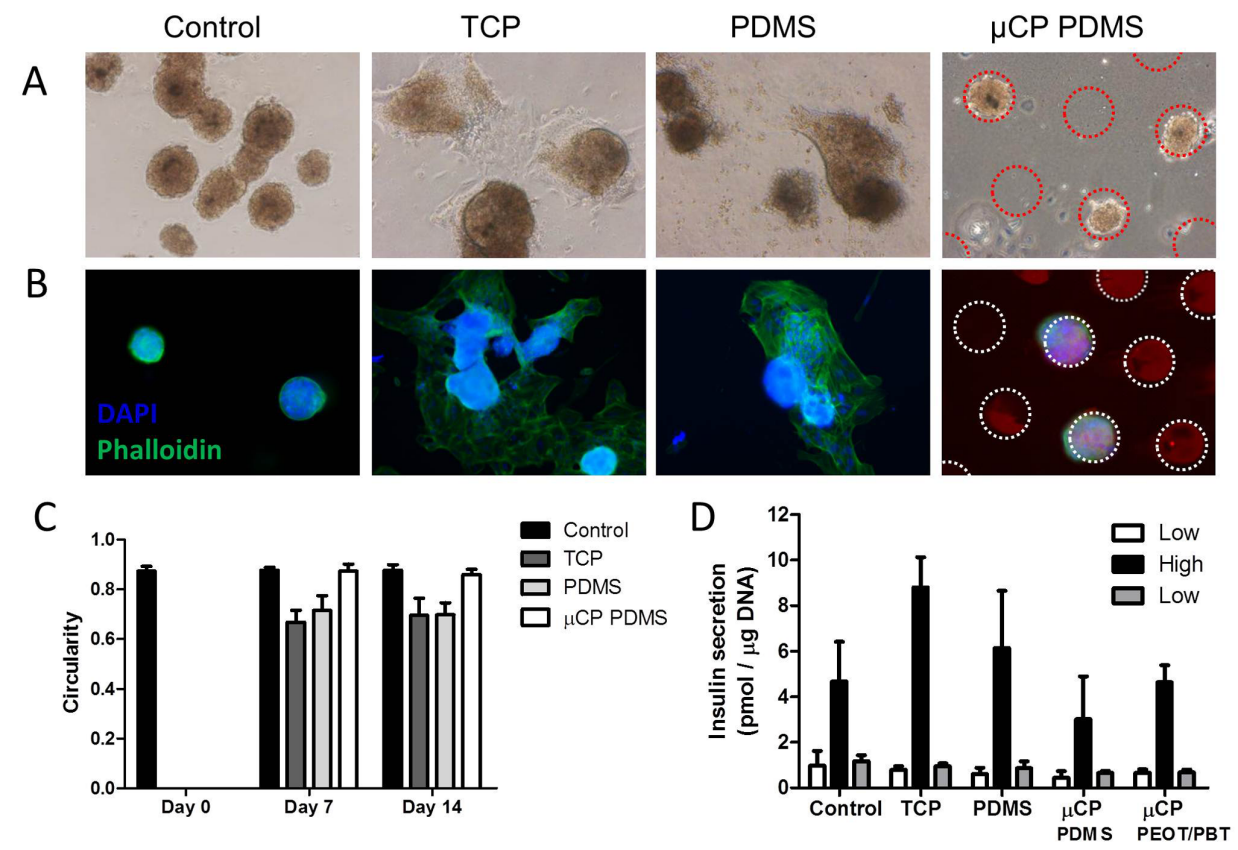

Figure 6.5: Human islets immobilized on microcontact printed substrates maintain their round morphology. (A) Human islets adhere and spread on tissue culture plastic (TCP) or PDMS fully coated with fibronectin (PDMS). On microcontact printed PDMS substrates ( $\mu$ CP PDMS), islets adhere while maintaining a round morphology similar to the free floating control islets. (B) Fluorescent microscopy shows no outgrow of cells from the islets that were seeded on microcontact printed PDMS. (C) Circularity measurements show that up to 14 days of culture, islets immobilized on microcontact printed PDMS remain rounded, resembling the free floating control islets. (D) Glucose-stimulated insulin secretion shows that islet immobilization on microcontact printed PDMS does not influence the islets glucose-responsiveness up to 14 days of culture. Error bars represent \pm SD. Scale bars represent $100 \mu \mathrm{m}$. 


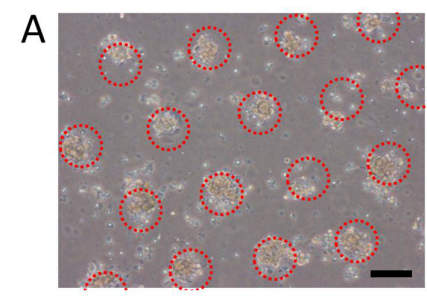

C

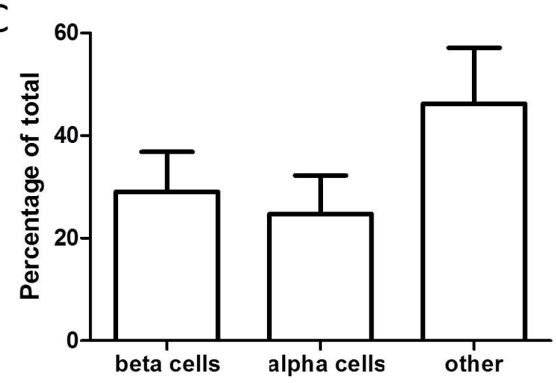

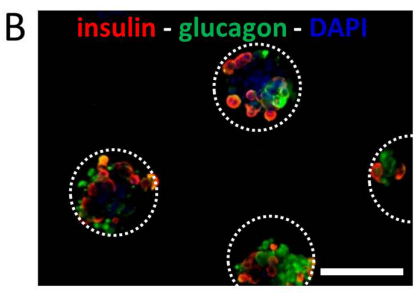

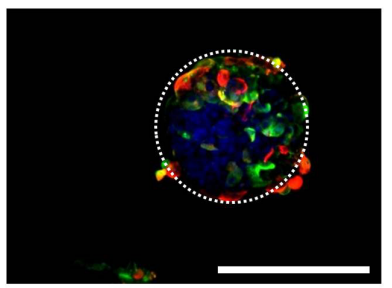

D

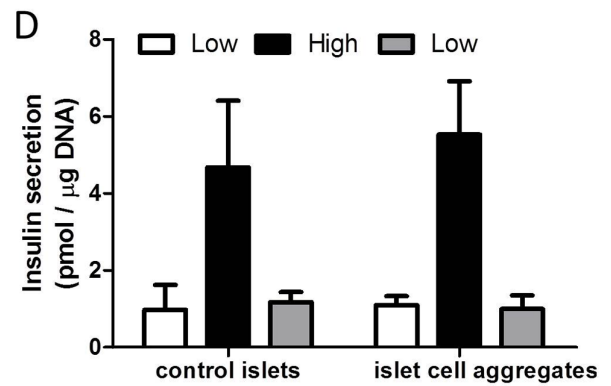

Figure 6.6: Dispersed human islet cells reassemble on fibronectinpatterned PDMS and remain glucose-responsive up to 7 days of culture. (A) Primary human islets were dispersed and single islet cells were seeded at 50,000 cells $/ \mathrm{cm}^{2}$ on fibronectin-patterned PDMS where they reassemble and form islet-like clusters. (B) Human islet cell aggregates show a heterogeneous architecture with alpha- and beta-cells dispersed throughout the aggregate, as shown by fluorescent immunostaining for insulin and glucagon. (C) Quantification of glucagon-positive alpha- and insulin-positive beta-cells within human islet cell aggregates. (D) Glucose-stimulated insulin secretion test was performed on human islet cell aggregates of compared with intact control islets. Islet cells aggregates show the same response as intact control islets. Error bars represent \pm SD. Scale bars represent $100 \mu \mathrm{m}$.

challenge as intact control islets of the same donor. We did not observe a significant difference between the stimulation indices of human islet cell clusters ( $\mathrm{SI}=5.3 \pm 1.8$ ), and intact control islets ( $\mathrm{SI}=5.5 \pm 1.8$ ) (Figure 6.6D).

\subsection{Discussion}

This study demonstrates the size-controlled cluster formation of INS-1E cells, cocultures of INS-1E cells and HUVECs, and dispersed human islet cells using microcontact printing. In addition, we showed that immobilization of intact human islets on microcontact printed substrates helps to preserve islet morphology and prevents islet aggregation.

Microcontact printing offers a fast and easy way to replicate patterns of fluorescently labelled fibronectin onto PDMS and PEOT/PBT block copolymer substrates. 
The created patterns consisted of uniform spots of fibronectin with a diameter of 100 $\mu \mathrm{m}$ and a low variation in fluorescent intensity, which shows that the printing process is very reliable. Microcontact printing on both PDMS and PEOT/PBT block copolymer substrates resulted in similar homogeneous patterns of fibronectin spots.

Production of uniform size-controlled cell clusters was optimized using INS-1E cells. Using microcontact printing, cell cluster dimensions could accurately be controlled by changing the initial cell seeding density. This is in line with other studies which demonstrated that a low number of cells per adherent area resulted in monolayered clusters, whereas at higher seeding densities multilayered cell clusters were formed [16]. Using microcontact printing to control cell aggregation will reduce variability and increase reproducibility of experimental results. In addition, it provides a tool to study of cluster-size dependent beta-cell function. Since close cell-cell contacts are required for proper beta-cell functioning, multicellular clusters are favorable. However, it has been shown that larger cell clusters $(>150 \mu \mathrm{m})$ suffer from severe cell death in the center due to diffusion limitations. A simulation study suggests that increasing the size of beta-cell clusters results in function gain, untill a plateau is reached at at approximately 100 cells per cluster, indicating that larger beta-cell clusters are not desirable [21]. Therefore we used 100,000 cells $/ \mathrm{cm}^{2}$ resulting in clusters with a diameter of $95.5 \pm 5.5 \mu \mathrm{m}$ and a height of $24.1 \pm 8.9 \mu \mathrm{m}$ for further studies. Patterned INS-1E cell clusters were shown to be viable and functional, as they expressed insulin and responded to a high-glucose stimulus. Glucose-responsiveness of patterned INS-1E clusters was higher compared to monolayer cultures on tissue culture plastic and fibronectin-coated PDMS. This correlates with another study showing that three-dimensional MIN6 cell clusters secrete more insulin than monolayer cultures of the same cell line [22-24]. Similar results were obtained using human beta-cells [11].

We generated co-cultures of INS-1E cells and HUVECs and studied the selfassembly of these cells on microcontact printed substrates. It was observed that in the 20/80 and 80/20 condition, a clear separation between INS-1E cells and HUVECs took place. This separation between both cell types is thought to be associated with cellular cohesiveness, which is mediated by differential expression of cell adhesion molecules. Others studies have demonstrated that neural cell adhesion molecule (NCAM) is responsible for the specific arrangement core-mantle arrangement of alpha and beta-cells in rat islets and that loss of this molecule results in a randomized distribution of cells [25]. Surprisingly, seeding equal amounts of both cells types (50/50) resulted in clusters containing a mixed cell population. However, it has to be noted that this experiment was only performed once and has to be repeated to validate these findings.

When cultured on adhesive surfaces, islets have the tendency to spread and form a monolayer in vitro. Losing their phenotype characteristics may eventually lead to loss of normal insulin secretion. We showed by restricting the binding area using microcontact printing, islet attachment onto a substrate can effectively be controlled which will help to reduce diffusion barriers and enhance transport of nutrients and oxygen to the cells. It has been reported that islet transplantation outcome is associated with maintenance of normal islet morphology. A recent study showed that separating islets, either by manual separation or by physical separation using matrigel, was effective in 
preventing islet fusion and maintaining individual islet morphology under the kidney capsule. This approach resulted in improved graft function and revascularization in diabetic mice [26]. Controlling islet attachment of islets onto a substrate using microcontact printing prevents islet aggregation and helps to preserve islet morphology, which might lead to improved transplantation outcome.

We studied the controlled generation of human islet cell clusters on microcontact printed spots of fibronectin. The patterned human islet cell clusters were homogeneous in size and showed a typical human islet architecture. Glucose-responsiveness of patterned human islet cell clusters was comparable to the intact control islets, which shows that dispersion and subsequent reassembly of islet cells on microcontact printed substrates does not influence their endocrine function. Reassembled human islet cell clusters that were produced using microcontact printing contained on average $29 \%$ beta-cells, $25 \%$ alpha cells and $46 \%$ other cells. Because the human donor islet tissue used for these experiments was $60-80 \%$ pure, which means that $40-80 \%$ of the cells are derived from exocrine tissue. Since these cells contribute to the total number of cells, the percentage of alpha- and beta-cells are slightly decreased whereas the percentage of other cells is relatively high. Taking into account that on average $70 \%$ of the human islet cells were endocrine cells, we can calculate (multiply by 100/70) that from the total amount of endocrine cells, $41 \%$ is beta-cell and $36 \%$ is alpha-cell. This correlates with the cellular composition of intact human islets which are, as has been quantitatively studied by others, composed of approximately $50 \%$ beta-cells, $35 \%$ alpha-cells, $<10 \%$ delta-cells, $<5 \%$ PP cells $[27,28]$.

Tailoring the dimensions of human islet cell clusters by islet dispersion and subsequent reassembly of islet cells may help to reduce diffusion barriers, improve islet survival and eventually enhance transplantation outcomes. Moreover, it has been reported that fragmented islets with disrupted integrity became well vascularized after transplantation, whereas intact islets were more or less avascular and suffer from ischemia [29]. This suggests that disrupting islet integrity by dispersion and subsequent reassembly of human islets on microcontact printing substrates, may support revascularization by recipient blood vessels. We showed that when co-culturing different ratios of INS-1E cells with huvecs, either completely mixed or seggregated cell clusters can be created. It has been demonstrated that co-culture of isolated islets with human endothelial cells results in increased islet angiogenesis [30]. Tuning the optimal cell to cell ratios of co-cultures of pancreatic islet cells with endothelial cells using microcontact printing could potentially aid in faster revascularization after transplantation.

\subsection{Conclusion}

Microcontact printing was used to succesfully produce patterns of fibronectin on PDMS and PEOT/PBT biomaterials. The approach presented in this study adresses two major issues in cell replacement strategies. First, this method enables the immobilization of intact human islets onto a biomaterial. This allows homogeneous seeding of intact islets, while maintaining their natural morphology and preventing 
islet fusion. Second, it provides a tool produce uniform human islet cell clusters and effectively control cell cluster size, which aids in generating islets with optimal dimensions. Using microcontact printing to modify a biomaterial as scaffold for beta-cells and islets may help to develop an optimal scaffold for pancreatic islet transplantation. 


\section{References}

1. Langer, R.M., Islet transplantation: lessons learned since the Edmonton breakthrough. Transplant Proc, 2010. 42(5): p. 1421-4.

2. Ryan, E.A., et al., Five-year follow-up after clinical islet transplantation. Diabetes, 2005. 54(7): p. 2060-9.

3. Martin, Y. and P. Vermette, Bioreactors for tissue mass culture: design, characterization, and recent advances. Biomaterials, 2005. 26(35): p. 7481-503.

4. Muschler, G.F., C. Nakamoto, and L.G. Griffith, Engineering principles of clinical cell-based tissue engineering. J Bone Joint Surg Am, 2004. 86-A(7): p. 1541-58.

5. Williams, S.J., et al., Diffusion into human islets is limited to molecules below 10 kDa. Tissue Cell, 2012. 44(5): p. 332-41.

6. Lehmann, R., et al., Superiority of small islets in human islet transplantation. Diabetes, 2007. 56(3): p. 594-603.

7. Nam, K.H., et al., Size-based separation and collection of mouse pancreatic islets for functional analysis. Biomed Microdevices, 2010. 12(5): p. 865-74.

8. O'Sullivan, E.S., et al., Rat islet cell aggregates are superior to islets for transplantation in microcapsules. Diabetologia, 2010. 53(5): p. 937-45.

9. Halban, P.A., et al., The possible importance of contact between pancreatic islet cells for the control of insulin release. Endocrinology, 1982. 111(1): p. 86-94.

10. Pipeleers, D., et al., Glucose-induced insulin release depends on functional cooperation between islet cells. Proc Natl Acad Sci U S A, 1982. 79(23): p. 7322-5.

11. Wojtusciszyn, A., et al., Insulin secretion from human beta cells is heterogeneous and dependent on cell-to-cell contacts. Diabetologia, 2008. 51(10): p. 1843-52.

12. Chen, C.S., et al., Geometric control of cell life and death. Science, 1997. 276(5317): p. 1425-8.

13. Hou, S., et al., Patterning of $293 \mathrm{~T}$ fibroblasts on a mica surface. Anal Bioanal Chem, 2009. 394(8): p. 2111-7.

14. Mrksich, M., et al., Using microcontact printing to pattern the attachment of mammalian cells to self-assembled monolayers of alkanethiolates on transparent films of gold and silver. Exp Cell Res, 1997. 235(2): p. 305-13.

15. Rozkiewicz, D.I., et al., Covalent microcontact printing of proteins for cell patterning. Chemistry, 2006. 12(24): p. 6290-7.

16. Mendelsohn, A.D., et al., Patterning of mono- and multilayered pancreatic betacell clusters. Langmuir, 2010. 26(12): p. 9943-9.

17. Mendelsohn, A.D., et al., Size-controlled insulin secreting cell clusters. Acta Biomater, 2012.

18. Merglen, A., et al., Glucose sensitivity and metabolism-secretion coupling studied during two-year continuous culture in INS-1E insulinoma cells. Endocrinology, 2004. 145(2): p. $667-78$.

19. Regehr, K.J., et al., Biological implications of polydimethylsiloxane-based microfluidic cell culture. Lab Chip, 2009. 9(15): p. 2132-9./

20. Buitinga, M., et al., Microwell scaffolds for the extrahepatic transplantation of islets of langerhans. PLoS One, 2013. 8(5): p. e64772.

21. Nittala, A., S. Ghosh, and X. Wang, Investigating the role of islet cytoarchitec- 
ture in its oscillation using a new beta-cell cluster model. PLoS ONE, 2007. 2(10): p. e983.

22. Brereton, H.C., et al., Homotypic cell contact enhances insulin but not glucagon secretion. Biochem Biophys Res Commun, 2006. 344(3): p. 995-1000.

23. Hauge-Evans, A.C., et al., Role of adenine nucleotides in insulin secretion from MIN6 pseudoislets. Mol Cell Endocrinol, 2002. 191(2): p. 167-76.

24. Luther, M.J., et al., MIN6 beta-cell-beta-cell interactions influence insulin secretory responses to nutrients and non-nutrients. Biochem Biophys Res Commun, 2006. 343(1): p. 99-104.

25. Esni, F., et al., Neural cell adhesion molecule (N-CAM) is required for cell type segregation and normal ultrastructure in pancreatic islets. J Cell Biol, 1999. 144(2): p. $325-37$.

26. Rackham, C.L., P.M. Jones, and A.J. King, Maintenance of islet morphology is beneficial for transplantation outcome in diabetic mice. PLoS ONE, 2013. 8(2): p. e57844.

27. Brissova, M., et al., Assessment of human pancreatic islet architecture and composition by laser scanning confocal microscopy. J Histochem Cytochem, 2005. 53(9): p. 1087-97.

28. Cabrera, O., et al., The unique cytoarchitecture of human pancreatic islets has implications for islet cell function. Proc Natl Acad Sci U S A, 2006. 103(7): p. 23349.

29. Henriksnas, J., et al., Markedly decreased blood perfusion of pancreatic islets transplanted intraportally into the liver: disruption of islet integrity necessary for islet revascularization. Diabetes, 2012. 61(3): p. 665-73.

30. Johansson, U., et al., Formation of composite endothelial cell-mesenchymal stem cell islets: a novel approach to promote islet revascularization. Diabetes, 2008. 57(9): p. 2393-401. 

Chapter 7

General conclusions and outlook 


\subsection{Abstract}

Although islet transplantation according to the Edmonton protocol has worldwide been conducted over 750 times, this therapy is not yet available for all patients diagnosed with type 1 diabetes. Research efforts to improve islet transplantation have mainly focused on 1) increasing the availability of donor islets, 2) improving islet function and survival and 3) develop alternative transplantation sites to improve long-term clinical outcome. This thesis describes several strategies that aim at optimizing the current islet transplantation procedure to improve clinical outcomes. This chapter discusses how the results described in this thesis may help to improve pancreatic islet transplantation and how these results may ultimately lead to better ways to treat type 1 diabetes.

\subsection{Role of imaging methods}

Efficient and non-destructive imaging methods are required to assess the quality of the tissue before transplantation $[1,2]$. Whereas conventional methods are invasive and require sample preparation and labeling, several non-invasive methods are available [3-5]. However, these methods show poor spatial resolution or do not provide functional characteristics of the islet tissue. In Chapter 3 and 4 of this thesis, we introduce Raman spectroscopy to characterize cells in a non-destructive and label-free manner. In Chapter 3, we explored the potential of this technique by monitoring the differentiation of both fixed and living human mesenchymal stromal cells in two-dimensional monolayer cultures. In Chapter 4, we take it a step further and use this technique to study more complex human donor tissue. We showed the use of Raman microspectroscopy to characterize human islets of Langerhans. Although Raman spectroscopy has been widely used to characterize cells and tissues in varieties of biological applications [6-10], we are the first to demonstrate high-resolution Raman spectroscopic imaging of human pancreatic islets in which we could identify the two main hormones secreted by these islets: insulin and glucagon. Correlating islet parameters to the final patient outcome after transplantation, could help to predict the effect of the therapy and would aid in selecting optimal tissue for transplantation [11, 12].

Apart from in vitro imaging of isolated donor islets of Langerhans, there is increasing interest in methods to monitor islet grafts in vivo. Although Raman spectroscopy allows imaging at submicrometer levels, the penetration depth of this technique is limited to a few hundred micrometers which limits the possibilities for using Raman spectroscopy for in vivo applications. Several other imaging techniques are currently available for in vivo detection of beta-cell mass. These include magnetic resonance imaging (MRI), ultrasound, computed tomography (CT), bioluminescence and fluorescence imaging, and the nuclear medicine techniques positron emission tomography (PET) and single-photon emission computed tomography (SPECT) [13,14]. Monitoring islet grafts and quantifying beta-cell mass in vivo would provide important biological insights and would facilitate a follow-up of pancreatic islet cell transplantation. 


\subsection{Generation of (artificial) islets}

Pancreatic islet transplantation will only become a feasible option for all patients with type 1 diabetes once the availability of donor tissue has been addressed. Islets from at least two to four donors are needed to achieve insulin independence in one patient. Researchers are investigating the possibilities of using alternative cell sources to create an unlimited supply of beta-cells. Embryonic stem cells (ESCs), adult stem or progenitor cells, or induced pluripotent stem cells (iPSCs) could theoretically deliver large quantities of beta-cells [15, 16]. Reports describe the generation of insulin-producing cells from human embryonic stem cells that respond to glucose tolerance tests and are capable of reversing hyperglycemia in diabetic mice [17, 18]. However, the risk of teratoma formation is a significant drawback to these cells.

It has been suggested that a three-dimensional environment is essential for proper differentiation of progenitor cells towards mature pancreatic beta-cells [19]. In addition, as described in Chapter 2, beta-cells require homotypic cell-cell contact to survive and function properly [20-22]. Therefore, recent research efforts have focused on the design of novel cell culture platforms to more closely resemble the cells native environment and improve cell-cell contact. Several microwell platforms have been developed and applied for three-dimensional culture of insulinoma cells, pancreatic progenitor cells, and rat islet cells [23-25]. However, optimized aggregation of islets cells of human origin has not yet been reported. We developed an agarose microwell platform for controlled aggregation of human donor islet cells to create islets with optimal dimensions, as described in Chapter 5. Tailoring aggregate dimensions could help to improve islet viability and increase the reproducibility of experimental results. Moreover, the platform facilitates the controlled generation of islets using alternative cell sources, thereby providing a valuable research tool for high-throughput in vitro drug screening.

We also showed in this chapter that dispersed human islet cells reassemble and form islet cell aggregates with a non-typical cellular arrangement. Although we did not observe reduced function when natural islet architecture was lost, the potential role of cellular organisation should not be neglected. A non-typical cellular arrangement may on the long term result in impaired islet function.

\subsection{Towards an implantable construct}

Intrahepatic islet transplantation is associated with severe islet loss which has stimulated the search for extrahepatic transplantation sites, including bioartificial transplantation sites. As described in Chapter 2, biomaterials can serve as an artificial transplantation site that can be tailored to mimic the natural islet microenvironment and provide optimal support to the cells. Various types of scaffolds have been assessed for extrahepatic islet transplantation. A recent study by our group describes the development of a porous PEOT/PBT polymer microwell scaffold to be used for the extrahepatic transplantation of islets of Langerhans. Human islets cultured in these scaffolds showed insulin release and insulin content comparable to control islets $[26]$. 
Islets have the tendency to spread and loose their phenotype when cultured on adhesive surfaces, which may eventually lead to loss of normal insulin secretion. Restricting islet cell attachment may help to reduce diffusion barriers and enhance transport of nutrients and oxygen to the cells. In Chapter 6, we introduce microcontact printing as an alternative method for controlled aggregation of human donor islet cells and at the same time restrict cell attachment. We produced patterns of fibronectin on PDMS and PEOT/PBT biomaterials on which controlled cell-cluster formation was achieved. Whereas others already demonstrated controlled formation of beta-cell clusters on microcontact printed substrates [27, 28], we are the first to show reaggregation of dispersed human donor islets. Restoring islet-ECM interactions by selectively incorporating ECM proteins in novel scaffold designs, like the porous PEOT/PBT microwell scaffold developed by our group, may help to improve transplantation outcome. Modifying the biomaterial using a combination of ECM proteins can further optimize the islet-containing construct. However, further research is needed to precisely determine the optimal (combination of) ECM compounds.

\subsection{Concluding remarks}

Despite all efforts, pancreatic islet transplantation is still considered experimental therapy. Researchers continue to look for alternative cell sources, methods to improve insulin-independence rates, and ways to eliminate the need for immunosuppressive agents. This should improve effectiveness of current islet transplantation procedures and should ultimately make this therapy available for every single individual suffering from type 1 diabetes. 


\section{References}

1. Ricordi, C., Quantitative and qualitative standards for islet isolation assessment in humans and large mammals. Pancreas, 1991. 6(2): p. 242-4.

2. Yamamoto, T., et al., Quality control for clinical islet transplantation: organ procurement and preservation, the islet processing facility, isolation, and potency tests. J Hepatobiliary Pancreat Surg, 2009. 16(2): p. 131-6.

3. Antkowiak, P.F., et al., Noninvasive assessment of pancreatic beta-cell function in vivo with manganese-enhanced magnetic resonance imaging. American Journal of Physiology-Endocrinology and Metabolism, 2009. 296(3): p. E573-E578.

4. Virostko, J., et al., Bioluminescence Imaging in Mouse Models Quantifies beta Cell Mass in the Pancreas and After Islet Transplantation. Molecular Imaging and Biology, 2010. 12(1): p. 42-53.

5. Moore, A., S. Bonner-Weir, and R. Weissleder, Noninvasive in vivo measurement of beta-cell mass in mouse model of diabetes. Diabetes, 2001. 50(10): p. 2231-6.

6. Notingher, I. and L.L. Hench, Raman microspectroscopy: a noninvasive tool for studies of individual living cells in vitro. Expert Rev Med Devices, 2006. 3(2): p. $215-34$.

7. Swain, R.J. and M.M. Stevens, Raman microspectroscopy for non-invasive biochemical analysis of single cells. Biochem Soc Trans, 2007. 35(Pt 3): p. 544-9.

8. Chan, J.W. and D.K. Lieu, Label-free biochemical characterization of stem cells using vibrational spectroscopy. J Biophotonics, 2009. 2(11): p. 656-68. 9. Chan, J.W., et al., Label-free separation of human embryonic stem cells and their cardiac derivatives using Raman spectroscopy. Anal Chem, 2009. 81(4): p. 1324-31.

10. Rong, X., et al., Real time detection of single living pancreatic beta-cell by laser tweezers raman spectroscopy: High glucose stimulation. Biopolymers, 2010.

11. Bertuzzi, F. and C. Ricordi, Prediction of clinical outcome in islet allotransplantation. Diabetes Care, 2007. 30(2): p. 410-7.

12. Street, C.N., et al., Islet graft assessment in the Edmonton Protocol: implications for predicting long-term clinical outcome. Diabetes, 2004. 53(12): p. 3107-14.

13. Ahlgren, U. and M. Gotthardt, Approaches for imaging islets: recent advances and future prospects. Adv Exp Med Biol, 2010. 654: p. 39-57.

14. Di Gialleonardo, V., et al., Imaging of beta-cell mass and insulitis in insulindependent (Type 1) diabetes mellitus. Endocr Rev, 2012. 33(6): p. 892-919.

15. Aguayo-Mazzucato, C. and S. Bonner-Weir, Stem cell therapy for type 1 diabetes mellitus. Nat Rev Endocrinol, 2010. 6(3): p. 139-48.

16. Furth, M.E. and A. Atala, Stem cell sources to treat diabetes. J Cell Biochem, 2009. 106(4): p. 507-11.

17. D'Amour, K.A., et al., Production of pancreatic hormone-expressing endocrine cells from human embryonic stem cells. Nat Biotechnol, 2006. 24(11): p. 1392-401.

18. Kroon, E., et al., Pancreatic endoderm derived from human embryonic stem cells generates glucose-responsive insulin-secreting cells in vivo. Nat Biotechnol, 2008. 26(4): p. 443-52.

19. Wang, X. and K. Ye, Three-dimensional differentiation of embryonic stem cells into islet-like insulin-producing clusters. Tissue Eng Part A, 2009. 15(8): p. 1941-52. 
20. Halban, P.A., et al., The possible importance of contact between pancreatic islet cells for the control of insulin release. Endocrinology, 1982. 111(1): p. 86-94.

21. Wojtusciszyn, A., et al., Insulin secretion from human beta cells is heterogeneous and dependent on cell-to-cell contacts. Diabetologia, 2008. 51(10): p. 1843-52.

22. Pipeleers, D., et al., Glucose-induced insulin release depends on functional cooperation between islet cells. Proc Natl Acad Sci U S A, 1982. 79(23): p. 7322-5.

23. Bernard, A.B., C.C. Lin, and K.S. Anseth, A Microwell Cell Culture Platform for the Aggregation of Pancreatic beta-Cells. Tissue Eng Part C Methods, 2012.

24. Gallego-Perez, D., et al., Micro/nanoscale technologies for the development of hormone-expressing islet-like cell clusters. Biomed Microdevices, 2012 . 14(4): p. $779-89$.

25. Ramachandran, K., et al., Engineering Islets for Improved Performance by Optimized Reaggregation in a Micromold. Tissue Eng Part A, 2012.

26. Buitinga M, et al., Microwell scaffolds for the extrahepatic transplantation of islets of Langerhans. PLos One, 2013.8(5): p. e64772.

27. Mendelsohn, A.D., et al., Patterning of mono- and multilayered pancreatic betacell clusters. Langmuir, 2010. 26(12): p. 9943-9.

28. Mendelsohn, A.D., et al., Size-controlled insulin secreting cell clusters. Acta Biomater, 2012. 


\section{Curriculum Vitae}

Janneke Hilderink was born on the $18^{\text {th }}$ of October 1985 in Enschede, The Netherlands. She started her study Biomedical Engineering at the University of Twente in 2003 and completed the bachelor degree with a three-months research project at the Medisch Spectrum Twente in Enschede. She continued with the master 'Molecular, Cellular and Tissue Engineering' and performed a five-months internship at the Nijmegen Centre for Molecular Life Sciences. In the beginning of 2009, she finished her studies with a master thesis entitled 'Optical imaging methods to monitor nutrient transport in tissue-engineered constructs', which she performed at the Tissue Regeneration department of the University of Twente (Prof. Dr. Clemens van Blitterswijk and Prof. Dr. Jan de Boer). In March 2009, she started her PhD research at the Department of Tissue Regeneration and the department of Developmental BioEngineering of the University of Twente under supervision of Prof. Dr. Clemens van Blitterswijk, Prof. Dr. Marcel Karperien and Dr. Aart van Apeldoorn. Her research, of which the results are described in this thesis, was focused on the optimization of pancreatic islet transplantation for patients with type 1 diabetes. Since July 2013 she has been working as a Medical Physicist trainee at the Medisch Spectrum Twente in Enschede under supervision of Dr. Ir. Ron Vaartjes. 



\section{List of Publications}

\section{Peer-reviewed papers}

Hilderink J, Otto C, Slump CH, Lenferink A, Engelse MA, van Blitterswijk CA, de Koning EJP, Karperien M, van Apeldoorn AA. Label-free detection of insulin and glucagon within islets of Langerhans using Raman spectroscopy. PLOS ONE. 2013. Accepted for publication.

Doorn J, Roberts SJ, Hilderink J, Groen N, van Apeldoorn AA, van Blitterswijk CA, Schrooten J, de Boer J. Insulin-like-growth-factor-I enhances proliferation and differentiation of human mesenchymal stromal cells in vitro. Journal of Tissue Engineering Part A. 2013 Aug;19(15-16):1817-28.

Masaeli E, Morshed M, Hossein Nasr-Esfahani M, Sadri S, Hilderink J, van Apeldoorn AA, van Blitterswijk CA, Moroni L. Fabrication, characterization and cellular compatibility of poly(hydroxyl alkanoate) composite nanofibrous scaffolds for nerve tissue engineering. PLOS ONE. 2013 Feb 27;8(2):e57157.

Liu J, Hilderink J, Groothuis TAM, Otto C, van Blitterswijk CA, de Boer J. Monitoring nutrient transport in tissue engineered grafts. Journal of Tissue Engineering and Regenerative Medicine. 2013 Jan 24 [Epub ahead of print].

Kunstar A, Leijten J, van Leuveren S, Hilderink J, Otto C, van Blitterswijk CA, et al. Recognizing different tissues in human fetal femur cartilage by label-free Raman microspectroscopy. Journal of Biomedical Optics. 2012 Nov 1;17(11):116012.

Ganser A, Roth G, van Galen JC, Hilderink J, Wammes JJ, Muller I, et al. Diffusiondriven device for a high-resolution dose-response profiling of combination chemotherapy. Analytical Chemistry. 2009 Jul 1;81(13):5233-40.

Hilderink J*, Spijker HS*, Carlotti F, Lange L, Engelse MA, van Blitterswijk CA, de Koning EJP, Karperien M, van Apeldoorn AA. Controlled aggregation of primary human pancreatic islet cells using agarose microwell chips. In revision.

* Shared first co-authorship 


\section{Manuscripts in preparation}

Hilderink J, Otto C, van Blitterswijk CA, Karperien M and van Apeldoorn AA. Label-free monitoring of human mesenchymal stromal cell differentiation using Raman spectroscopy.

Hilderink J, Brinkmann J, Cabanas J, Bat E, de Koning EJP, Engelse MA, van Blitterswijk CA, Karperien M and van Apeldoorn AA. Size-controlled cluster formation of human pancreatic islet cells on protein patterned biomaterials.

\section{Abstracts selected for oral presentation}

Hilderink J, de Koning EJP, Engelse MA, Otto C, van Blitterswijk CA, Karperien M, van Apeldoorn AA. Non-destructive quality control for islet transplantation using Raman spectroscopy. NBTE, 2011, Lunteren, The Netherlands.

Hilderink J, de Koning EJP, Engelse MA, Otto C, van Blitterswijk CA, Karperien M, van Apeldoorn AA. Non-destructive quality control for islet transplantation using Raman spectroscopy. ESAO, 2011, Porto, Portugal.

Hilderink J, de Koning EJP, Engelse MA, Otto C, van Blitterswijk CA, van Apeldoorn AA, Karperien M. Non-invasive quality control for islet transplantation using Raman spectroscopy. TERMIS-EU, 2011, Granada, Spain.

\section{Abstracts selected for poster presentation}

Hilderink J, Marchioli G, Engelse MA, de Koning EJP, van Blitterswijk CA, Alblas J, Karperien M, Moroni L, van Apeldoorn AA. Pseudo-islets as a model to study biomaterials for islet of Langerhans transplantation. TERMIS-World, 2012, Vienna, Austria.

Hilderink J, de Koning EJP, Engelse MA, Otto C, van Blitterswijk CA, van Apeldoorn AA, Karperien M. Raman spectroscopic characterization of pancreatic islets for transplantation in type 1 diabetes patients. NBTE, 2010, Lunteren, The Netherlands.

Hilderink J, Otto C, van Blitterswijk CA, van Apeldoorn AA. Strategy to noninvasively monitor development of engineered tissues. NBTE, 2009, Lunteren, The Netherlands. Best poster award. 


\section{Acknowledgements}

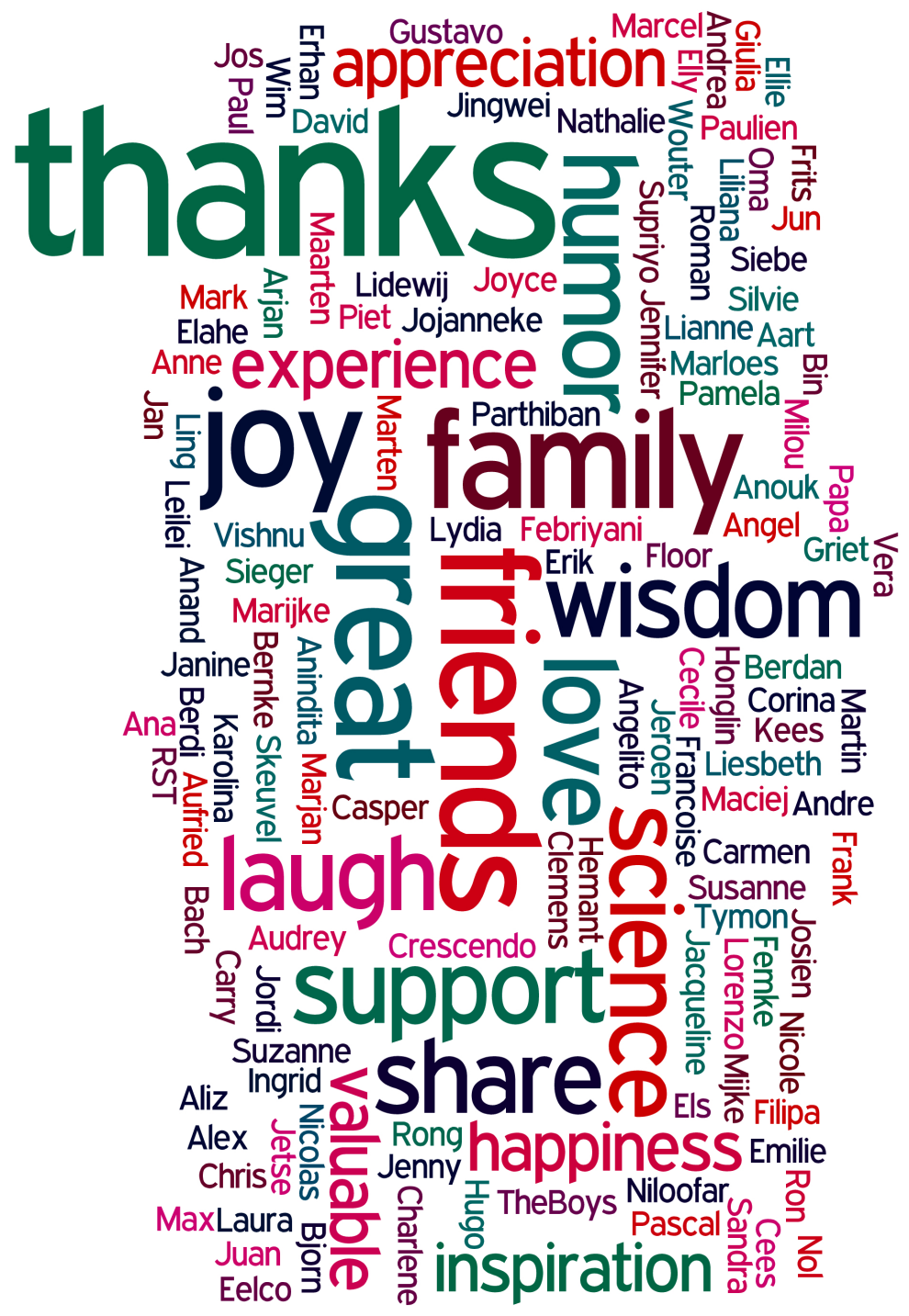






